\title{
Reservoir Characterization and Static Earth Modeling for Potential CO2 Storage in Upper Pennsylvanian Cyclothems of Midcontinent, USA
}

Valerie Lynn Smith

vSmith@ValKat.us

Follow this and additional works at: https://researchrepository.wvu.edu/etd

Part of the Geology Commons

\section{Recommended Citation \\ Smith, Valerie Lynn, "Reservoir Characterization and Static Earth Modeling for Potential CO2 Storage in Upper Pennsylvanian Cyclothems of Midcontinent, USA" (2020). Graduate Theses, Dissertations, and Problem Reports. 7593.}

https://researchrepository.wvu.edu/etd/7593

This Dissertation is protected by copyright and/or related rights. It has been brought to you by the The Research Repository @ WVU with permission from the rights-holder(s). You are free to use this Dissertation in any way that is permitted by the copyright and related rights legislation that applies to your use. For other uses you must obtain permission from the rights-holder(s) directly, unless additional rights are indicated by a Creative Commons license in the record and/ or on the work itself. This Dissertation has been accepted for inclusion in WVU Graduate Theses, Dissertations, and Problem Reports collection by an authorized administrator of The Research Repository @ WVU.

For more information, please contact researchrepository@mail.wvu.edu. 
Reservoir Characterization and Static Earth Modeling for Potential C02 Storage in Upper Pennsylvanian Cyclothems of Midcontinent, USA

Valerie Lynn Smith

Follow this and additional works at: https://researchrepository.wvu.edu/etd

Part of the Geology Commons 


\title{
Reservoir Characterization and Static Earth Modeling for Potential $\mathrm{CO}_{2}$ Storage in Upper Pennsylvanian Cyclothems of Midcontinent, USA
}

\author{
Valerie L. Smith \\ Dissertation submitted \\ to the Eberly College of Arts and Sciences \\ at West Virginia University \\ in partial fulfillment of the requirement \\ for the degree of \\ Doctor of Philosophy \\ in \\ Geology \\ Thomas Wilson, Ph.D., Chair \\ Tim Carr, Ph.D., Co-chair \\ Joe Donovan, Ph.D. \\ Jaime Toro, Ph.D. \\ Dengliang Gao, Ph.D. \\ Alan Brown, Ph.D. \\ Department of Geology and Geography
}

Morgantown, West Virginia

2020

Keywords: Pennsylvanian Cyclothems, $\mathrm{CO}_{2}$ Storage, Static Earth Modeling, CarbonSafe

(C) Copyright 2020 Valerie L. Smith 


\section{ABSTRACT \\ Reservoir Characterization and Static Earth Modeling for Potential $\mathrm{CO}_{2}$ Storage in Upper Pennsylvanian Cyclothems of Midcontinent, USA Valerie L. Smith}

This dissertation details the estimation of $\mathrm{CO}_{2}$ storage volume using reservoir characterization and the building of static earth models in two papers: 1) for Sleepy Hollow Field in Red Willow County, Nebraska and, 2) for Huffstutter Field, Phillips County, Kansas. These models are used to obtain estimates of $\mathrm{CO}_{2}$ storage capacity in stacked carbonate intervals of the Pennsylvanian Lansing and Kansas City groups (LKC). The LKC constitutes a regional succession of interbedded carbonates and shales. Located over the Cambridge Arch of Nebraska, these interbedded units were evaluated for carbon storage potential. Understanding the occurrence of carbonate porosity among the confining shale units in the LKC is key for developing a $\mathrm{CO}_{2}$ storage strategy for the Integrated Midcontinent Stacked Carbon Storage Hub Project as part of DOE-NETL's Carbon Storage Assurance Facility Enterprise initiative. Petrophysical analysis of wireline logs and existing core samples from Sleepy Hollow and nearby oilfields were studied and show that oolitic grainstone offers superior effective porosity and permeability. Intermediate quality rock is peloidal and skeletal grainstones. The poorest reservoir quality rocks are siliciclastic mudrocks, which include claystones and mudstones. Adsorption of $\mathrm{CO}_{2}$ by clay (predominantly illite) was not investigated here. While illite and other clay minerals can adsorb $\mathrm{CO}_{2}$, mud and clay-rich rocks have been treated as caprocks given their low permeability. Gamma ray log response clearly indicated the depositional cyclicity and was employed in gamma ray facies development to delineate carbonate rocks from mud-dominant lithologies using gamma ray log thresholds. Storage resource estimates were based on the resulting effective porosity model consisting of $\mathrm{CO}_{2}$ storage in saline zones vertically stacked with potential EOR reservoirs in oil-bearing carbonate intervals. Results show that for Sleepy Hollow's LKC, storage is estimated at 602,157 tonnes $\mathrm{CO}_{2} /$ mile $^{2}\left(232,494\right.$ tonnes $\mathrm{CO}_{2} / \mathrm{km}^{2}$ ), and Huffstutter is 443,355 tonnes $\mathrm{CO}_{2} / \mathrm{mile}^{2}$ $\left(171,180\right.$ tonnes $\left.\mathrm{CO}_{2} / \mathrm{km}^{2}\right)$ when using a storage efficiency factor of 0.1. Although reservoir depth and 
thickness impose strong conditions on estimated storage capacity, effective porosity was the key parameter that explains the difference in storage between these two fields. The combined area of these two fields is 43 square miles $\left(111.3 \mathrm{~km}^{2}\right.$ ) fields with potential LKC carbon storage of 8.4 Mt at Sleepy Hollow and 13.0 Mt at Huffstutter. This research lays the foundation for a regional stacked carbon storage hub where captured carbon would be piped to existing oilfields for carbon storage and enhanced oil recovery along the Cambridge Arch and the Central Kansas Uplift. Carbon dioxide could also be stored proximal to corn ethanol plants as part of the storage hub.

Permeability models were prepared for both sites following customary workflows for $\mathrm{CO}_{2}$ storage projects. Neither permeability models were used here as they do not explicitly fit into the NETLCO2SCREEN (Goodman et al., 2016) method of storage estimation. However, both were developed in support of ongoing research and would require the contribution of a reservoir engineer to run flow simulations. Flow simulations have been conducted by Battelle $(2018,2019)$ as part of full field-scale storage assessments for these sites with injection targets of 50 million tonnes $\mathrm{CO}_{2}$ over 30 years.

This dissertation provides valuable research for:

- the correlation of LKC members in the subsurface based on gamma ray log response with clarification of LKC zonal definitions between Nebraska and Kansas

- implementation of a cyclothem model and how that model applies to the Cambridge Arch of Nebraska and the Central Kansas Uplift

- application of a gamma ray (log) facies model for defining reservoir zones and caprocks within the Pennsylvanian cyclothems, and for adjusting effective porosity logs.

- demonstration of how the LKC can vary between oilfields and how differences in carbonate rock reservoirs can affect the net $\mathrm{CO}_{2}$ storage capacity

- the establishment of a workflow for three-dimensional petrophysical modeling of the LKC and similar Pennsylvania units in the area. 


\section{Acknowledgments}

I am very thankful for the knowledge, guidance, support, and friendship of my committee chair, Dr. Thomas Wilson. I am so appreciative of his encouraging words and sage advice as I navigated the many obstacles towards the completion of my degree. I could not ask for a better academic advisor and mentor during my graduate study at WVU.

My thanks also go to my committee members Dr. Tim Carr (co-chair), Dr. Alan Brown, Dr. Joe Donovan, Dr. Jaime Toro, and Dr. Dengliang Gao, for their constructive comments and suggestions. Alan Brown has been a great mentor for enabling my $\sim 7$ years of training through my employment with Schlumberger. I also have many thanks to Bob Will, Michael Carney, and Carolyn Bauerschlag, who encouraged me to pursue and complete a dissertation. While maintaining my career in geology, I am very thankful to Battelle Memorial Institute and the WVU Geology Department for permitting the necessary flexibility to enable my academic success. This thanks also includes Hope Stewart for dealing with my many concerns regarding student status, tuition waivers, and filing the necessary forms with the University.

I am also very thankful for the collaboration and knowledge shared by Isis Fukai, Andrew Duguid, Dana Divine, R.M. Joeckel, and Dan Blankenau. Together, we have laid the groundwork for $\mathrm{CO}_{2}$ storage and $\mathrm{CO}_{2}$-EOR in Pennsylvanian carbonates in Nebraska and Kansas. I have a special thanks to Matt Joeckel for his mentorship in guiding me through sedimentary petrology. His genuine interest in fostering my research of the Lansing and Kansas City groups was paramount to the success of my work.

I have many thanks for the technical support provided by James Damico, Roland Okwen, and Charles Monson of the Illinois State Geological Survey, Champaign, IL. This team was instrumental in fulfilling work on an earlier version of my dissertation involving $\mathrm{CO}_{2}$ storage assessments in the Mt. Simon Sandstone.

I am grateful for the friendship of my academic peers, including Zach Cotter, Payam Kavousi, Molly Kish, and Tom Paronish, as we matured as geologists and brought our degrees to fruition. 


\section{Table of Contents}

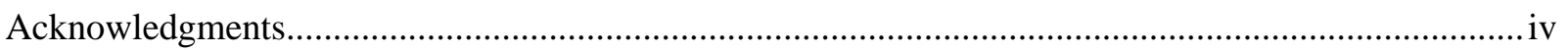

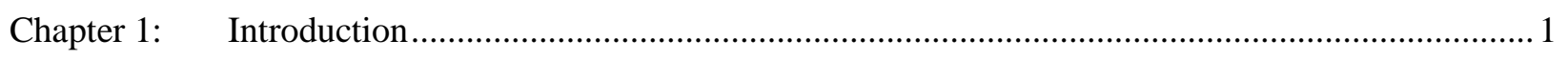

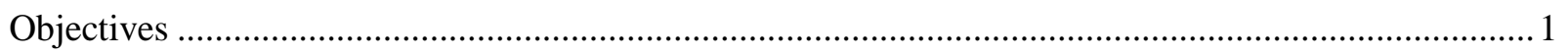

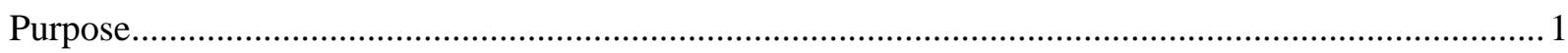

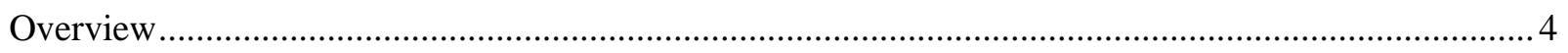

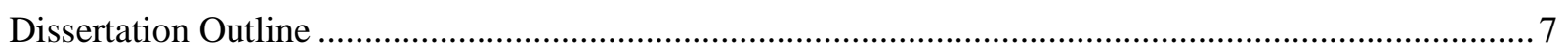

Chapter 2: $\quad$ Lansing-Kansas City correlations from Outcrop Belt to Red Willow County, NE. ........... 10

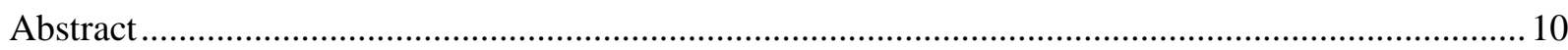

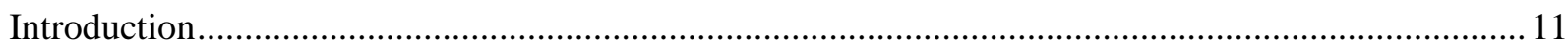

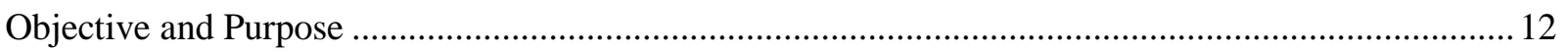

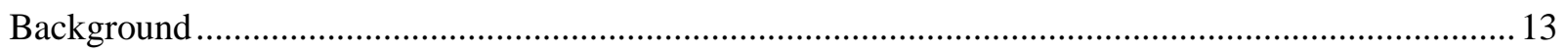

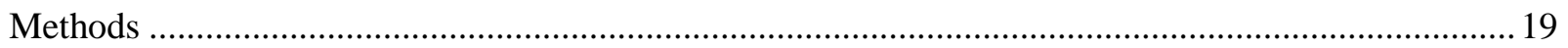

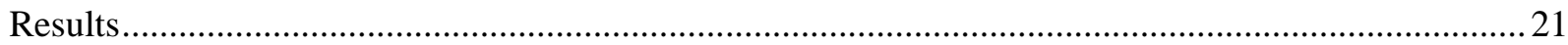

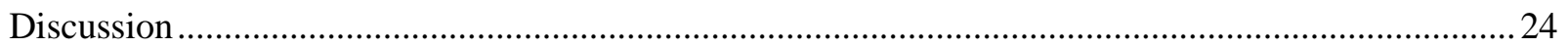

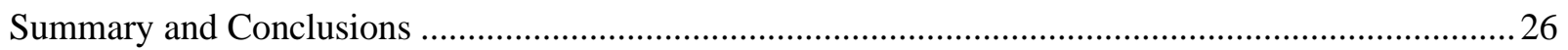

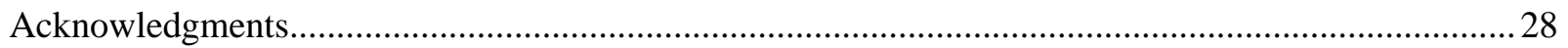

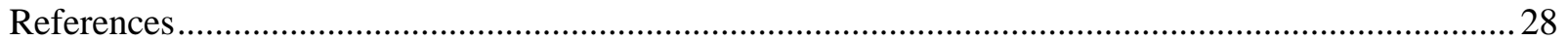

Chapter 3: $\quad$ Reservoir Characterization and Static Earth Model for Potential $\mathrm{CO}_{2}$ Storage in Upper

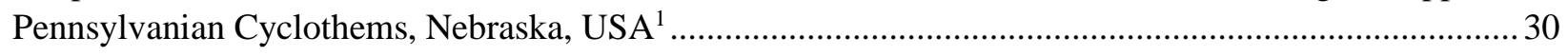

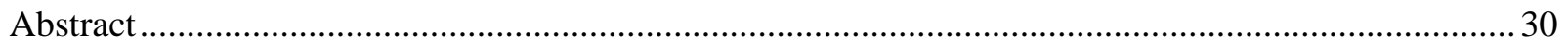

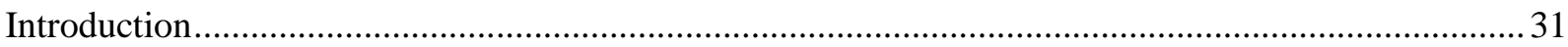

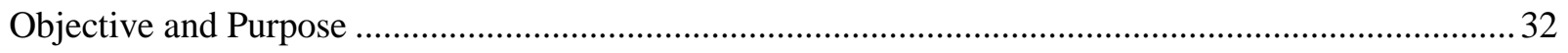

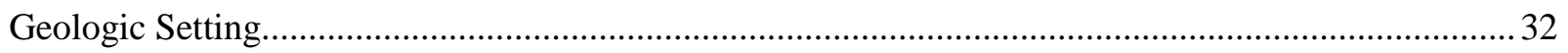

Establishing a Stratigraphic Framework for the Static Earth Model .................................................38

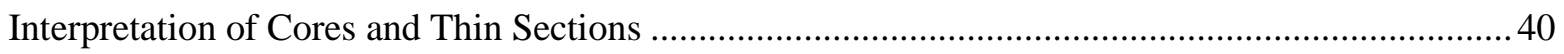

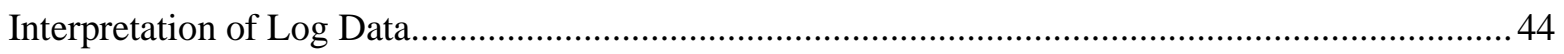

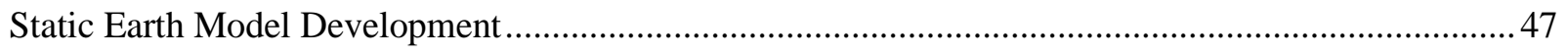

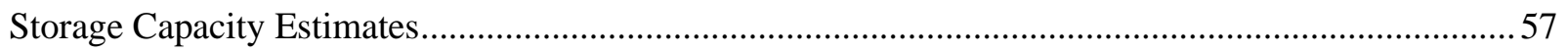

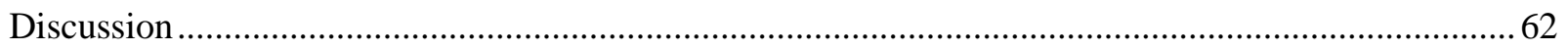

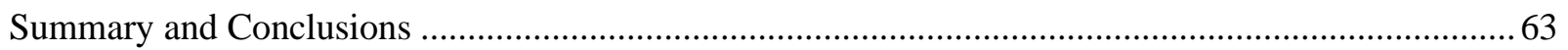

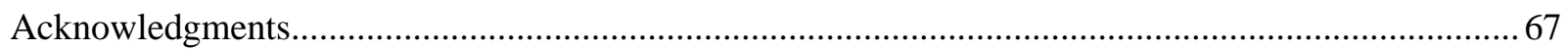

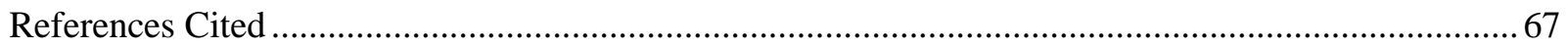

Chapter 4: Static Earth Modeling and $\mathrm{CO}_{2}$ Storage in Lansing and Kansas City Groups, Huffstutter

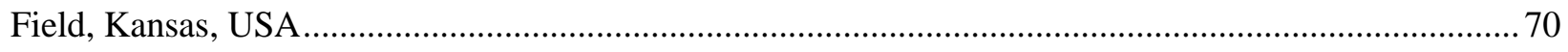




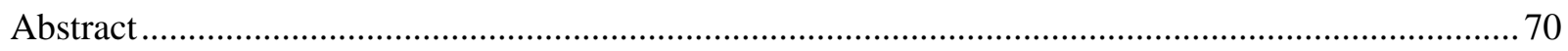

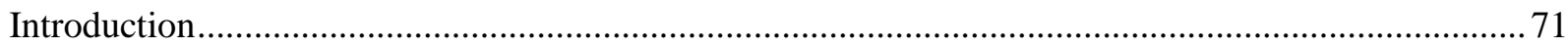

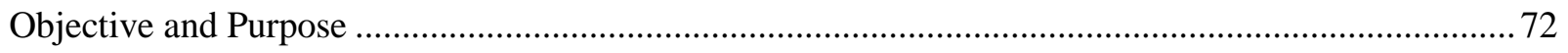

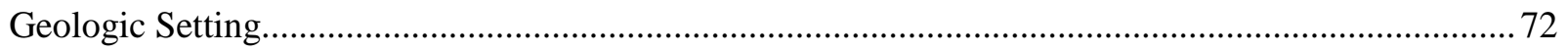

Static Earth Model Development (Methodology) ............................................................................ 79

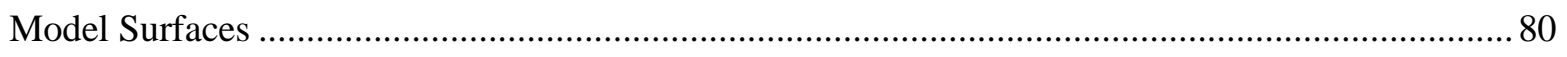

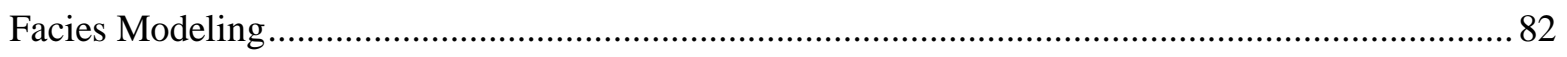

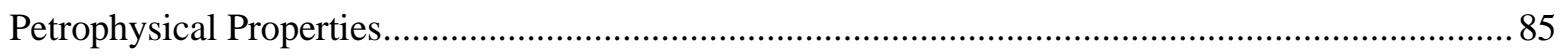

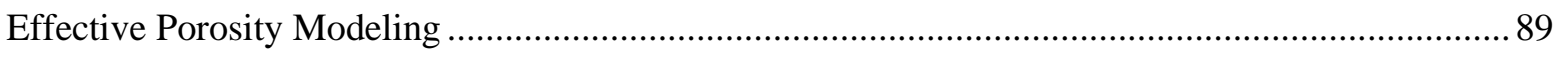

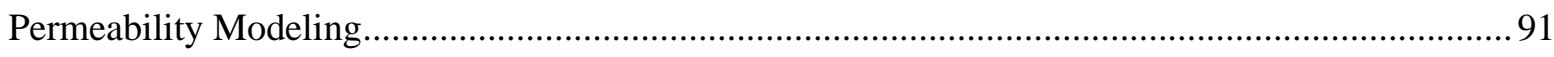

Pressure, Temperature, and $\mathrm{CO}_{2}$ Density Modeling .............................................................. 93

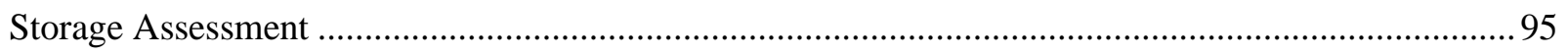

Contrast and Comparison between Huffstutter and Sleepy Hollow Field ...........................................98

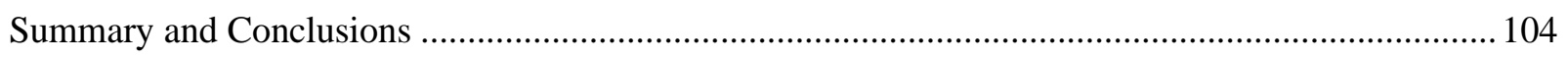

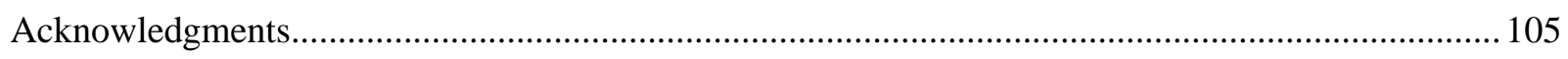

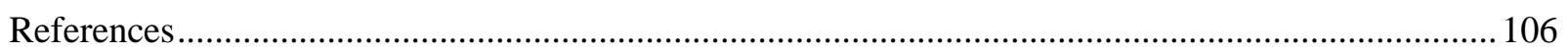

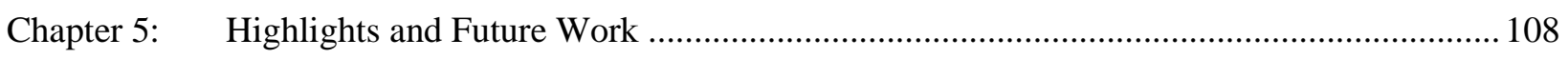

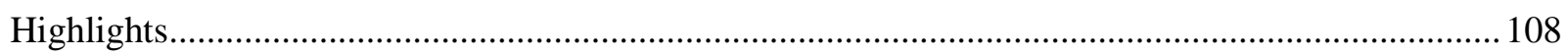

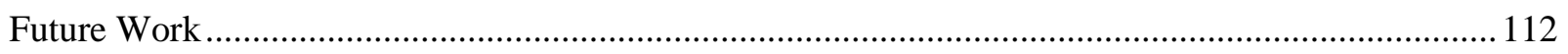

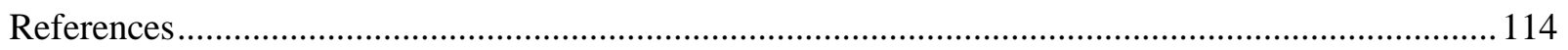

\section{List of Figures}

Figure 1-1. (a) Sleepy Hollow Field (SHF) is located on the southwestward limb of the Cambridge Arch in Red Willow County, Nebraska, and is the primary study area for this research.. …............................ 2

Figure 1-2. Interpretation of the Cambridge Arch based on an east-west well section. ............................ 3 Figure 1-3. a) Simplified stratigraphic column showing the deep saline formations of interest and overlying caprocks evaluated in both study areas.................................................................... 4

Figure 2-1. Location of Red Willow County Nebraska. The Pennsylvanian outcrops in eastern Kansas. . 12 Figure 2-2. Kansas-type cyclothem, as described by Heckel (1986)..................................................... 14

Figure 2-3. Example Kansas-type cyclothem from eastern Kansas (Kansas City area) with sea level

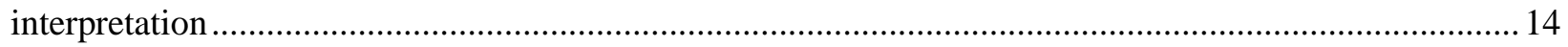
Figure 2-4. Lansing - Kansas City zonal lettering conventions based on well logs. a) Kincaid b) Trimble,

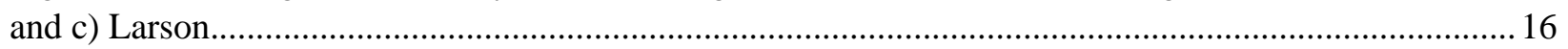


Figure 2-5. Example well logs with member interpretations by Burchett (1983). Resistivity peaks represent limestone members; these members have been labeled as zone letters "A" through "H.".......... 17 Figure 2-6. Example well section showing correlation of Lansing - Kansas City Groups, Watney (1980).

Figure 2-7. Map view of Pennsylvanian stratigraphy with well section between potential $\mathrm{CO}_{2}$ storage areas in the west and outcrops to the east.

Figure 2-8. Stratigraphic nomenclature and correlative, LKC zonal letter conventions. Modified after

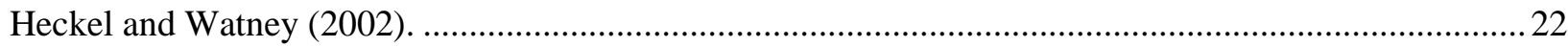
Figure 2-9. Regional subsurface well section of the Pennsylvanian Lansing - Kansas City groups reveals post-depositional structural features on the LKC..............................................................................2

Figure 2-10. Regional well section flattened on the top of the LKC zone "A" .....................................25 Figure 3-1. (a) Location of Sleepy Hollow Field on the southwestward limb of the Cambridge Arch in

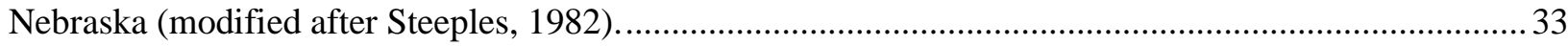

Figure 3-2. (a) Simplified stratigraphic column showing the deep saline formations of interest and overlying caprocks evaluated in the Cambridge Arch study area.

Figure 3-3. Gamma ray (GR) and total porosity logs (PHIT) for six wells fully penetrating the LKC

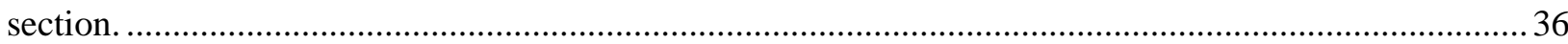
Figure 3-4. Pennsylvanian carbonate cycle. (a) Example of Kansas-type cyclothem, modified after Heckel (1986). (b) Adaptation of the carbonate cycle. .. 39 Figure 3-5. Interpretation of Pennsylvanian carbonate cycles at Sleepy Hollow Field and their correlative

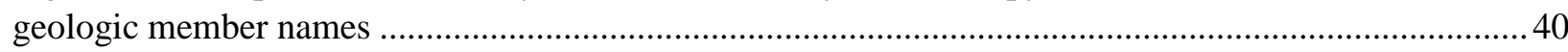
Figure 3-6. Representative sidewall core samples and thin sections with gamma ray logs...................... 43 Figure 3-7. Logs from stratigraphic test well SHRU 86A showing LKC zones "A" through "F."............46 Figure 3-8. Workflow for the construction of geocellular models to calculate the effective storage resource potential for $\mathrm{CO}_{2}$.

Figure 3-9. Well section across SEM. a) Well section showing LKC carbonate rock top picks based on GR logs. b) Map view of SEM area and location of well section at left.

Figure 3-10. SEM surfaces and framework. a) Surfaces representing the tops of key carbonate rock units; vertical black lines are wells. b) SEM with zones defined by surfaces ................................................50 Figure 3-11. LKC facies delineation based on gamma ray log thresholds ...........................................52 Figure 3-12. GR facies model based on GR log response described in Table 3. (a) Cross section through GR facies model. (b) Oblique 3D view of GR facies model. .................................................................53 Figure 3-13. Effective porosity logs for carbonate, mudrock, and shale lithologies. ...............................54 Figure 3-14. Effective porosity ( $\varphi$ e) model. Porous LKC zones correspond to carbonate units. ...............56 Figure 3-15. Permeability (K) model. Permeable LKC zones correspond to limestone units...................57 Figure 3-16. LKC pressure and temperature conditions from the SHRU 86A well.................................58

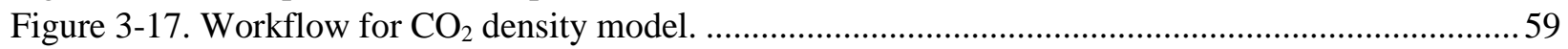
Figure 3-18. Slice through the SEM showing the computed $\mathrm{CO}_{2}$ mass storage for the LKC. ..................62 Figure 4-1. (a) Location of Huffstutter Field on the east limb of the Central Kansas Uplift.....................73 Figure 4-2. Simplified stratigraphic column showing the deep saline formations of interest and overlying

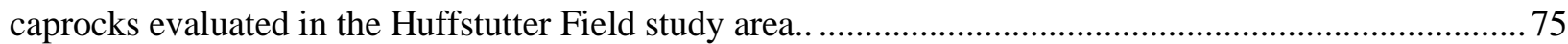
Figure 4-3. Log cross-section showing carbonate cyclicity observed in gamma ray well logs correlated

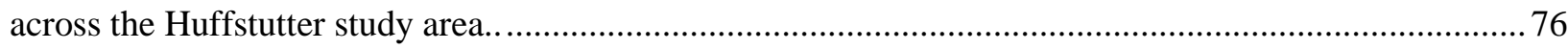
Figure 4-4. Contoured structural map for the top of the LKC at Huffstutter Field. Reference datum is

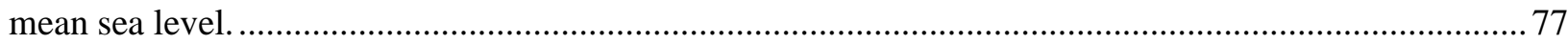
Figure 4-5. Example well logs and formation tops from the Huffstutter Field O'Neill 'A' 3 well............. 79 Figure 4-6. Tasks for SEM development and storage assessment. ......................................................... 80 
Figure 4-7. Oblique view of SEM area with wells, well tops, and surfaces.

Figure 4-8. Model zones for the Huffstutter Field SEM. SEM is 6,000 ft by 6,000 ft. Petrophysical modeling was conducted for zones from the Oread Member down to the base of the Kansas City........... 82 Figure 4-9. Methods for well log upscaling into SEM grid cells along vertical well trajectory................. 84 Figure 4-10. GR facies model for the Huffstutter study area................................................................ 84 Figure 4-11. Cross-plots of multipliers used to re-scale effective porosity logs (equation 4-3) and permeability logs (equation 4-4) for mudrock intervals where GR log $>70$. 87 Figure 4-12. Permeability-porosity cross-plot for Sleepy Hollow Field core samples. This regression was used to predict a permeability log from porosity logs (PHIe).

Figure 4-13. Example porosity and permeability log adjustments for the Huffstutter SEM. ...................8 88 Figure 4-14. Effective porosity model (a) Cross-section through the effective property model. (b) Oblique view of effective porosity model. Effective porosity histograms from well logs to 3D property model.... 90 Figure 4-15. Permeability model (a) Cross-section through the permeability model. (b) Oblique view of permeability model. (c) Permeability histograms from well logs to property model. ..............................92 Figure 4-16. Pressure, temperature, and density models prepared for the Huffstutter SEM .................... 94 Figure 4-17. Computed $\mathrm{CO}_{2}$ mass storage, by cell, for the LKC........................................................97 Figure 4-18. The relative depth and thickness of LKC SEMs for Sleepy Hollow and Huffstutter Fields are

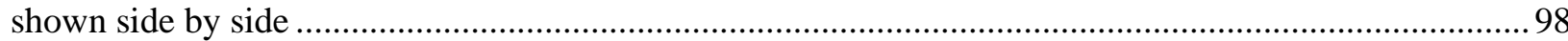

Figure 4-19. Example well correlation between Sleepy Hollow Field and Huffstutter Field.................... 99 Figure 4-20. Comparison of LKC volume by facies based on SEMs from Sleepy Hollow and Huffstutter

Fields. 100

Figure 4-21. A percentage-wise comparison of LKC volume by facies based on SEMs from Sleepy

Hollow and Huffstutter Fields. 101

Figure 4-22. Comparison of SEM effective porosity for LKC limestone units of Sleepy Hollow and Huffstutter Fields (GR facies code 0). 101

Figure 4-23. Comparison of SEM properties filtered on carbonate rock, GR facies code 0 ...... 102

Figure 4-24. Porosity-foot net maps for LKC section for Sleepy Hollow and Huffstutter SEMs 103

\section{List of Tables}

Table 2-1. Well index table for well section (Figures 2-7, 2-9 and 2-10, and Plate 1) .........................21

Table 2-2. Summary of Pennsylvanian Lansing - Kansas City zonal-lettering conventions.................... 23

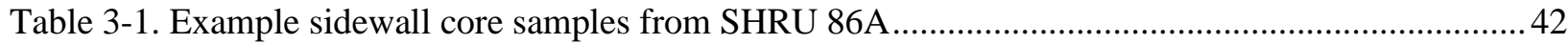

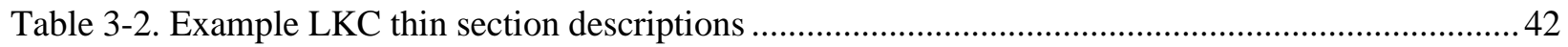

Table 3-3. Gamma ray facies and codes used in this study for Pennsylvanian cyclothems. .....................51

Table 3-4. Carbon storage resource estimates for the LKC carbonate reservoir units, SHF. ...................61

Table 4-1. Carbon storage resource estimated by zone for the LKC carbonate reservoir units, HF.......... 96 


\section{Acronyms and Abbreviations}

CarbonSAFE Carbon Storage Assurance Facility Enterprise

$\mathrm{CO}_{2}$ carbon dioxide

DST

Drill Stem Test

DOE

Department of Energy

$\mathrm{E}_{\mathrm{An} / \mathrm{At}}$

net-to-total area

$\mathrm{E}_{\mathrm{d}}$

$\mathrm{E}_{\mathrm{hn} / \mathrm{hg}}$

microscopic displacement efficiency

$\mathrm{E}_{\text {saline }}$

net-to-gross thickness

$\mathrm{E}_{\mathrm{v}}$

$\mathrm{E}_{\text {фe/ } / \text { tot }}$

ECS

EOR

$\mathrm{ft}$

GRFS

GR

$\mathrm{HF}$

storage efficiency factor

volumetric displacement efficiency

effective-to-total porosity

Elemental Capture Spectroscopy (well log)

Enhanced Oil Recovery

feet

Gaussian Random Function Simulation

$\mathrm{h}_{\mathrm{g}}$ Gamma Ray, commonly gamma ray well log

Huffstutter Field

IMSCS-Hub Integrated Midcontinent Stacked Carbon Storage-Hub

$\mathrm{kg} \quad$ kilogram

K Permeability

KGS Kansas Geological Survey

$\mathrm{km} \quad$ kilometer

LKC Lansing and Kansas City Groups

Ls Limestone

m meter

$M_{\mathrm{CO} 2} \quad$ computed mass of supercritical $\mathrm{CO}_{2}$ at reservoir conditions

MD Measured Depth

$\mathrm{mD} \quad$ millidarcy

mi mile

$\mathrm{MPa} \quad$ Megapascals

Mt megatonne (million metric tons)

NETL National Energy Technology Laboratory

NMR Nuclear Magnetic Resonance (well log)

NPHI Neutron Porosity log

NOGCC Nebraska Oil and Gas Conservation Commission

$\mathrm{P} \quad$ Pressure

psi Pounds per square inch

P10 $10 \%$ probability

P50 50\% probability

P90 90\% probability

SEM Static Earth Model

Sh Shale

SHF Sleepy Hollow Field

SHRU 86A Sleepy Hollow Reagan Unit well 86A (drilled June 2019)

$\mathrm{T}$ temperature

$\rho_{\mathrm{CO} 2}$ density of carbon dioxide

$\phi_{\mathrm{e}} \quad$ effective porosity

$\phi_{\text {tot }} \quad$ total formation porosity

$V c \quad$ bulk volume 


\section{Chapter 1: Introduction}

\section{Objectives}

The principal objective of this research is to provide reliable estimates of the accessible $\mathrm{CO}_{2}$ storage within the Lansing and Kansas City Groups (LKC). This dissertation provides detailed characterization and assessment of $\mathrm{CO}_{2}$ storage potential in Pennsylvanian age cyclic carbonate sequences of the midcontinent US. The region being evaluated includes two potential storage sites, one is Sleepy Hollow Field, Nebraska, and the other, Huffstutter Field, Kansas (Figure 1-1 and Figure 1-2). This assessment requires accurate geologic characterization and the development of petrophysical models. These models enable $\mathrm{CO}_{2}$ storage calculations and the evaluation of $\mathrm{CO}_{2}$ injection strategies and are key for performing $\mathrm{CO}_{2}$ flow simulations. One objective of this dissertation has been to resolve accurate porosity and permeability for the Lansing and Kansas City Groups (LKC) (Figure 1-3). A key challenge has been the discrimination of effective porosity within these cycles and developing accurate permeability estimates. This line of research has implications for similar cyclic carbonate sequences like the overlying Douglas, Shawnee, and Wabaunsee Groups (Figure 1-3). Other objectives include the correlation of members within the LKC, understanding how these members fit into a cyclothem model, and how these members form reservoir-seal pairs. These objectives are all tied together in the development of two site-specific geologic models, one at Sleepy Hollow Field, Nebraska, the other at Huffstutter Field, Kansas.

\section{Purpose}

This dissertation research is a key component in support of the Integrated Midcontinent Stacked Carbon Storage (IMSCS) Hub Project as part of DOE (Department of Energy)-NETL's (National Energy Technology Laboratory) Carbon Storage Assurance Facility Enterprise (CarbonSAFE) initiative. The primary outgrowth of the CarbonSAFE project is to develop a regional carbon storage hub where captured carbon will be piped from $\mathrm{CO}_{2}$ sources (commonly corn ethanol plants) to existing oilfields for carbon storage and enhanced oil recovery (EOR). 

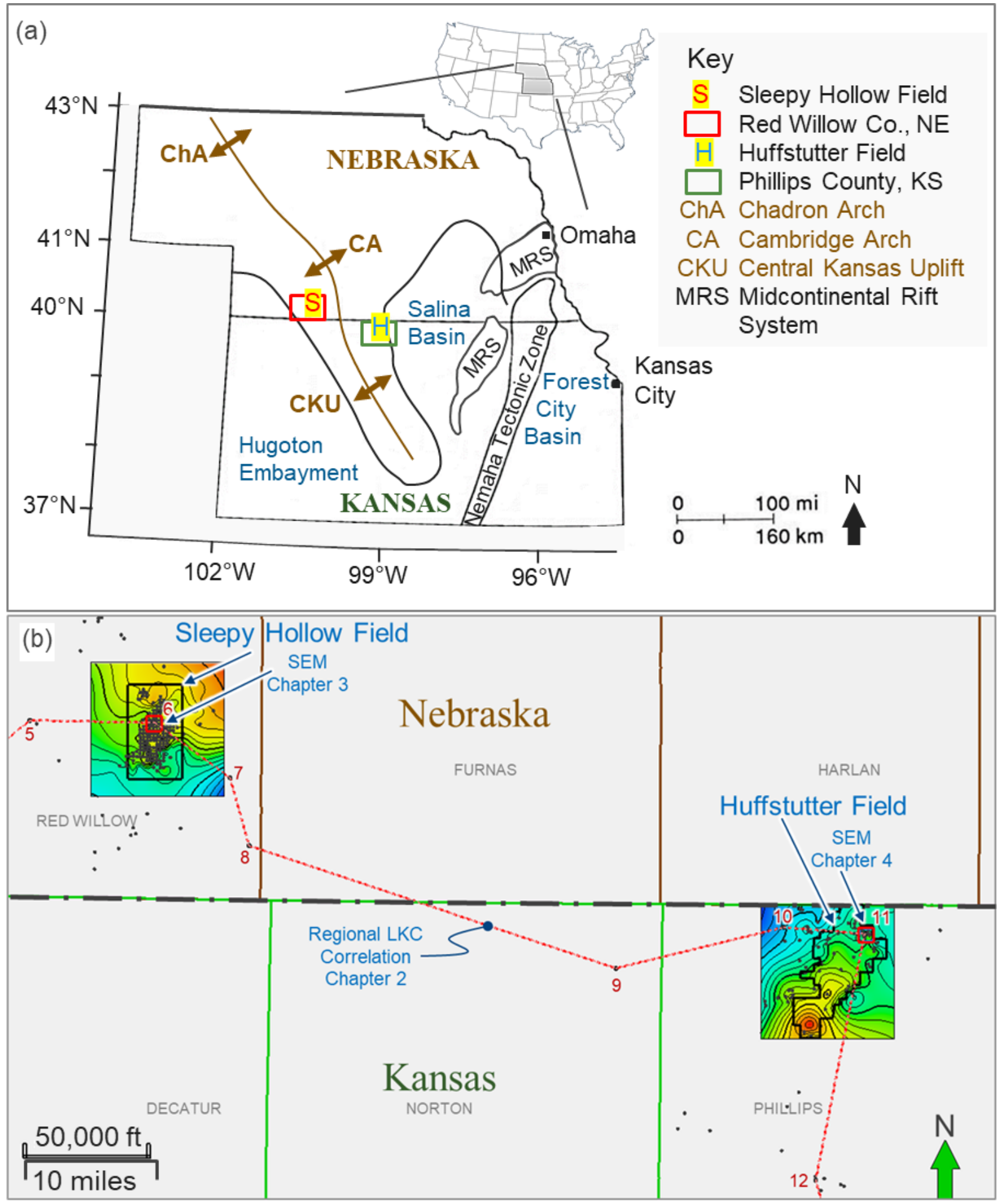

Figure 1-1. (a) Sleepy Hollow Field (SHF) is located on the southwestward limb of the Cambridge Arch in Red Willow County, Nebraska, and is the primary study area for this research. A secondary storage area included Huffstutter Field (HF), Kansas. Image modified from Steeples (1982). (b) Map of SHF and HF showing locations of static earth models developed for this research and a portion of the regional LKC well correlation line. 


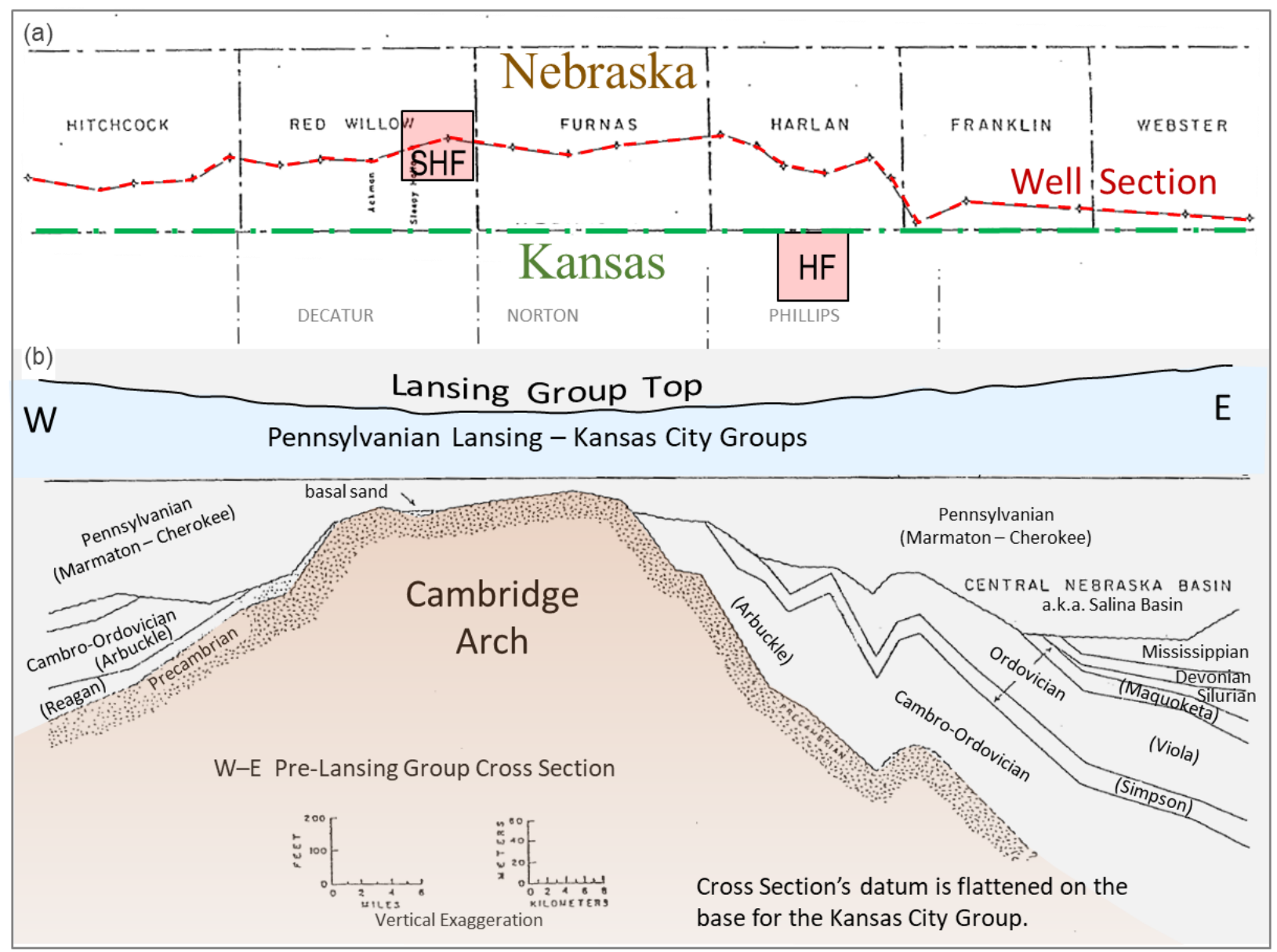

Figure 1-2. Interpretation of the Cambridge Arch based on an east-west well section. (a) County map showing Sleepy Hollow Field (SHF) and Huffstutter Field (HF) study areas along with well locations (+). (b) Cambridge Arch interpretation flanked by lower Paleozoic strata representative of the geologic structure at the time of LKC deposition. Modified from Larson (1962). 


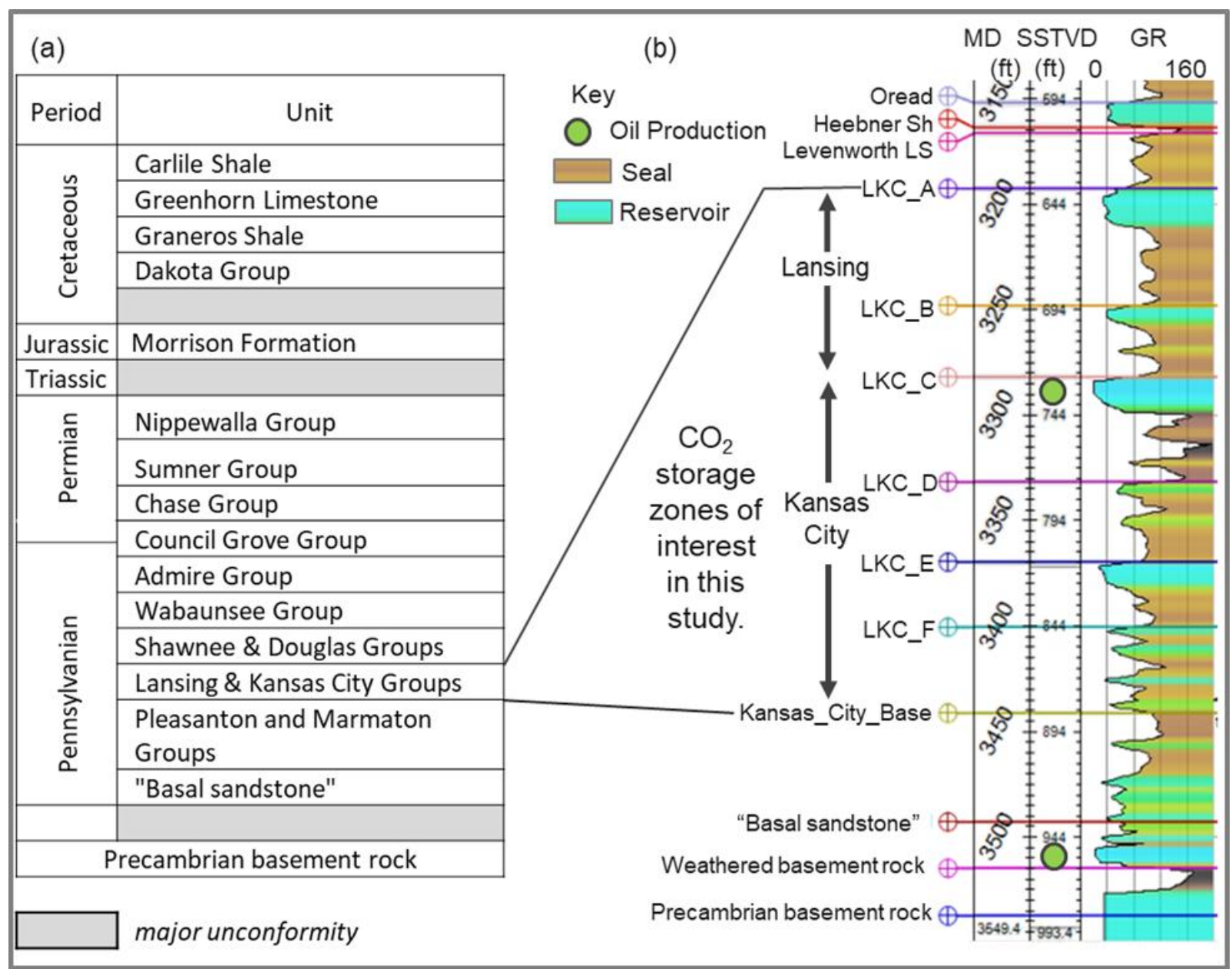

Figure 1-3. a) Simplified stratigraphic column showing the deep saline formations of interest and overlying caprocks evaluated in both study areas, Battelle, 2018. b) Example gamma ray log for the LKC Groups indicating reservoir and seal pairs, carbonate, and mudrock, respectively.

\section{Overview}

Preliminary work for the IMSCS-Hub project involved reservoir characterization, and developing relationships with oilfield operators, $\mathrm{CO}_{2}$ producers, and pipeline specialists. Considerations for potential storage sites in this region include site access, data availability, proximity to existing pipe-line corridors, and the willingness of oilfield owners to enable $\mathrm{CO}_{2}$ storage research. A study area in southwestern Nebraska was selected and centered on Sleepy Hollow Field (SHF) in Red Willow County. Potential reservoir units and seals were determined to be of sufficient depth and quality for $\mathrm{CO}_{2}$ storage. These units are comprised of Pennsylvanian cyclic carbonates spanning a measured depth of 2850 to 3450 feet (869 to $1052 \mathrm{~m})$. Within this $600 \mathrm{ft}(183 \mathrm{~m})$ section, the Lansing - Kansas City Groups (LKC) portion offered the 
best data availability due to hydrocarbon production from a few oil-bearing zones. Individual LKC zones at Sleepy Hollow Field are approximately 35 -feet thick and are comprised of carbonate rock units and mudrock-dominant units as summarized below:

- Carbonate (limestone rock of varying textures and reservoir quality)

- Mudstone (clay, silt, and quartz dominated, massive or blocky but not platy; pedogenic features are common)

- Shale (platy or fissile, often dark or black, correlates with marine "core shale").

For $\mathrm{CO}_{2}$ storage projects, the concept of a $\mathrm{CO}_{2}$ storage unit commonly consists of a distinctive reservoir and seal pair. Storage considerations in the LKC consist of several stacked reservoir and seal intervals, and some of the LKC intervals are hydrocarbon-bearing. In practice, the models developed in this study can include considerations for enhanced oil recovery in addition to storage in saline units. Localized accumulations of oil are the exception, and saline LKC zones are generally the rule. Given the geographical extent of the LKC section, storage estimates prepared here treat the LKC as saline. The Kansas-type cyclothem model was used as a starting point for defining a stratigraphic framework. This framework was key in the development of the 3D geocellular petrophysical models. Application and limitations of these models are explored and discussed.

This research integrates existing oilfield data to form a Static Earth Model (SEM) framework for estimating potential $\mathrm{CO}_{2}$ storage capacity for Pennsylvanian LKC cyclic carbonates. Reservoir characterization began with the collection and digitization of vintage well logs from SHF. Existing subsurface interpretations (Burchett, 1983; Busch, 1977; Dubois, 1985; Watney, 1980; and Young, 2011) from nearby oilfields were used to supplement the geologic model concept and guide the geologic model development of these potential storage units. From the existing core, new core data was acquired and included laboratory-measured porosity and permeability, XRD (X-ray diffraction) data, and thin sections from five wells in the SHF area. In June 2019, this data was supplemented by the drilling of a stratigraphic test well (IMSCS-Hub, SHRU 86A) to gather new core samples and obtain a modern-day 
suite of logs. Nuclear magnetic resonate (NMR) (Appel, 2004) logging was a crucial addition for providing further lines of evidence in distinguishing effective porosity. However, rugose conditions in the borehole and mudcake buildup prevented reliable, quantitative determination of effective porosity from the NMR $\log$.

As part of the regional expansion and subsurface characterization for the IMSCS-Hub project, the geomodeling workflow developed for SHF was applied to Huffstuter Field in Kansas, 55 miles (88.5 km) to the SE of Sleepy Hollow Field (Figure 1-1). Due to a different depositional location, my research shows that the lithologic components of the cycles differ from those at SHF. Well correlations between these two fields show that at Huffstutter Field, the top of the LKC is $3410 \mathrm{ft}(1039 \mathrm{~m})$ measured depth and $\sim 230$ feet $(70 \mathrm{~m})$ deeper than at SHF. With a thickness of $\sim 216 \mathrm{ft}(66 \mathrm{~m})$, the LKC Group at Huffstuter Field is comparable to that of Sleepy Hollow Field at $250 \mathrm{ft}(76.2 \mathrm{~m})$. However, at Huffstutter Field we see a thinning of mudstones, and, based on well log signatures, the transgressive marine shale units are more pronounced. This evidence suggests a more basin-ward position of the Huffstutter Field and affects the net storage potential.

As specified by NETL, the target $\mathrm{CO}_{2}$ injection rate for the IMSCS-Hub is 50 million metric tonnes over 30 years. The SEM work developed for these fields incorporates the properties and framework for estimating $\mathrm{CO}_{2}$ storage capacity for the cyclic carbonates in this area. This research reflects the most accurate models one can develop at this time. Advancement of these models would require new fieldspecific data, like drill stem tests for the determination of pressure and temperature gradients at Huffstutter Field. These models can be used in various simulations to estimate enhanced oil recovery volumes and $\mathrm{CO}_{2}$ storage volumes. The model can also be used to determine optimal locations of injection and production wells as part of the regional scale storage effort. The results detailed in this dissertation will show that a field-scale LKC section alone is insufficient to meet NETL's target of 50 million metric tonnes over 30 years. In fact, the LKC plus all adjacent carbonate units in Pennsylvanian cyclothems would be required as part of a $50 \mathrm{M}$ tonne $\mathrm{CO}_{2}$ injection strategy along the Cambridge Arch (Battelle 2018, 2019). 


\section{Dissertation Outline}

This dissertation covers the reservoir characterization efforts for midcontinent $\mathrm{CO}_{2}$ stacked storage and includes three main chapters. The first chapter introduces the Upper Pennsylvanian that represents the key $\mathrm{CO}_{2}$ storage formations in this research. This is followed by two site-specific reservoir characterization efforts, one in Nebraska, the other in Kansas.

In the first paper, Chapter 2 details the lithostratigraphic correlations that support the reservoir characterization and static earth modeling efforts along the Cambridge Arch and the Central Kansas Uplift (Figure1-1). The focus of this paper is on the correlation of members within the Pennsylvanian Lansing - Kansas City Groups (Figure1-2). These groups are comprised of interbedded carbonate and mudrock members, and their correlations have been obscured by the existence of two different zonal lettering conventions long used by petroleum-industry operators, one in Nebraska and another in Kansas. Ambiguities in the correlation were addressed by the preparation of a regional well section that traces the formations of Pennsylvanian LKC Groups eastward to the outcrop belt in eastern Kansas (and, to a lesser degree, southeastern Nebraska) where the units were formally named, and later revised by Heckel and Watney (2002).

This work serves as a valuable key for unlocking correlation challenges among existing wells, and their legacy LKC top picks while facilitating reservoir characterization efforts, especially when comparing storage options across state lines. Furthermore, this paper discusses the Kansas-type cyclothem model prepared by Heckel (1986) and its use in regional subsurface correlation and potential utility in model development for assessing $\mathrm{CO}_{2}$ storage potential.

In Chapter 3 I introduce Sleepy Hollow Field and review the factors controlling and limiting reservoir quality within Pennsylvanian cyclic carbonates of southwestern Nebraska. Representative rock types (lithofacies) for different flow units will be identified using sequence stratigraphic concepts based on well $\log$ signatures and core interpretations within the framework of the Heckel (1986) Kansas-type

cyclothem model. These facies will be the building blocks of the Static Earth Model (SEM) representation 
of the petrophysical characteristics of stacked cyclic carbonate sequences that form the proposed storage field. The SEM is then used for computing an estimate of carbon storage capacity for the LKC.

While Heckel (1986) described the general character of Pennsylvanian cyclothems, accurate field-scale quantitative petrophysical analyses of these carbonate formations do not exist. Conducting this analysis represents a key challenge for carbon storage assessment of these reservoir intervals. For example, existing neutron porosity logs are a great indicator of changes occurring between the LKC mudrock and the limestone units. However, preparing effective porosity logs using V-shale (shale volume) corrections has been problematic due to significant gamma ray spikes associated with marine shales. The IMSCS-Hub project gathered additional petrophysical data to better quantify values for effective porosity and permeability of the target formations. These data were obtained from a stratigraphic test well drilled at SHF in June 2019. A modern-day log suite, coring, and drill stem testing of cyclic carbonates provide comprehensive data on the physical properties of target formations. The new data allows the calibration of legacy log data, thereby increasing their usefulness in SEM construction. The integration of this data and resulting petrophysical modeling represents the most sophisticated geologic model ever developed for this area.

Chapter 4 builds on the regional carbon storage assessment by extending the geologic interpretations from the Sleepy Hollow Field to the Huffstutter Field (HF) in Kansas, located 55 miles $(88.5 \mathrm{~km})$ the southeast (Figure 1-1). Huffstutter Field is located on the eastern limb of the Central Kansas Uplift, an extension of the Cambridge Arch. Here, based on well log signatures, the LKC appears to have more carbonate rock than that seen in Sleepy Hollow Field. These differences are attributed, in part, to the depositional location within the shallow, Pennsylvanian epicontinental sea and is accompanied by the presence of more dominant, marine shales. Thin Pennsylvanian black shales produce a very strong gamma ray response and can serve as key marker beds to aid in the correlation of LKC members. The outgrowths of the Chapter 4 effort define the framework for carbon storage along the eastern limb of the 
Central Kansas Uplift. This research quantifies the stratigraphic and structural differences between these two fields (Sleepy Hollow and Huffstutter) and discusses storage differences.

Finally, Chapter 5 summarizes the highlights of the LKC research and describes the direction of ongoing and future work. 


\title{
Chapter 2: Lansing-Kansas City correlations from Outcrop Belt to Red Willow County, NE.
}

\begin{abstract}
The Pennsylvanian Lansing - Kansas City (LKC) Groups consist of a regional succession of interbedded carbonates and mudrocks. These groups are being evaluated for $\mathrm{CO}_{2}$ storage opportunities in saline zones that are vertically stacked with potential EOR reservoirs in oil-bearing carbonate strata. In the mid-continent, USA, the study area includes the Cambridge Arch and the Central Kansas Uplift, where the reservoir characterization efforts require the lithostratigraphic correlation of members within the LKC Groups. Correlations have been confounded by the existence of two different zonal lettering conventions long used by petroleum-industry operators, one in Nebraska and another in Kansas. Ambiguities in the correlations were addressed by preparing a regional well section that traces individual LKC members eastward to the outcrop belt in eastern Kansas where the units were formally named and later revised by Heckel and Watney (2002).
\end{abstract}

Mudrock and carbonate successions are recognized and generally fit into a transgressive regressive model associated with cyclic deposition related to late Paleozoic Gondwanan ice ages and sealevel change. From outcrops and well log response, this research correlates LKC zonal letter designations with their corresponding named members. The well section includes wells found in the literature (pre-2000) where formation names and letters were used. Regressive mudstone units in the LKC thicken on the Cambridge Arch, and black shales are less common there, changing the expression of cyclothems relative to the outcrop-based model. The result of this work serves as a valuable key for unlocking correlation challenges among existing wells and their legacy LKC member top picks. Furthermore, this will help reservoir characterization efforts conducted through the Integrated Midcontinent Stacked Carbon Storage (IMSCS) Hub project, especially when comparing LKC member storage options across counties or state lines. 


\section{Introduction}

The IMSCS project required evaluation and correlation of Pennsylvanian midcontinent cyclic carbonates for carbon storage opportunities within saline units. The project also involves the identification of areas within these reservoirs where $\mathrm{CO}_{2}$-EOR options exist within the oil-bearing Lansing - Kansas City (LKC) Groups. This work required the correlation of formations within oilfields, and for a regional assessment, across the Nebraska - Kansas state line. Both Nebraska and Kansas have significant oilfield databases consisting of thousands of wells, well logs, and well tops. Geologists faced with correlating members of the LKC will quickly recognize that there are inconsistent LKC zonal lettering conventions between Nebraska and Kansas. These lettering conventions trace their origin to oilfield operators. In Nebraska, the Nebraska Oil and Gas Conservation Commission (NOGCC) maintains these well records and uses the LKC zonal lettering convention of "A" through "F." In Kansas, the Kansas Geological Survey (KGS) maintains their oilfield records where the LKC zones are lettered A through $\mathrm{K}$, and some of the letters are often omitted, presumably due to local pinch-outs. The Heebner Shale and the Stark Shale are two named, key maker beds commonly used for correlations.

Regardless of the convention, these zones are traceable to eastern Kansas where Pennsylvanian outcrops are exposed, often in road cuts. It is here that these formations (the lettered zones) have been formally recognized and named. This paper takes advantage of the revised stratigraphic nomenclature by Heckel and Watney (2002) and, through well log signatures, correlates the members of the Lansing Kansas City from Eastern Kansas northwestward to Red Willow County, Nebraska (Figure 2-1). Along the well section and in the discussion below, key wells found in the literature (Burchett, 1983; Busch, 1977; Dubois, 1985; Watney, 1980; and Young, 2011) have been included so one may compare both lettered and named member picks. Together, these members can be accurately correlated in the region in support of the IMSCS-Hub project. 


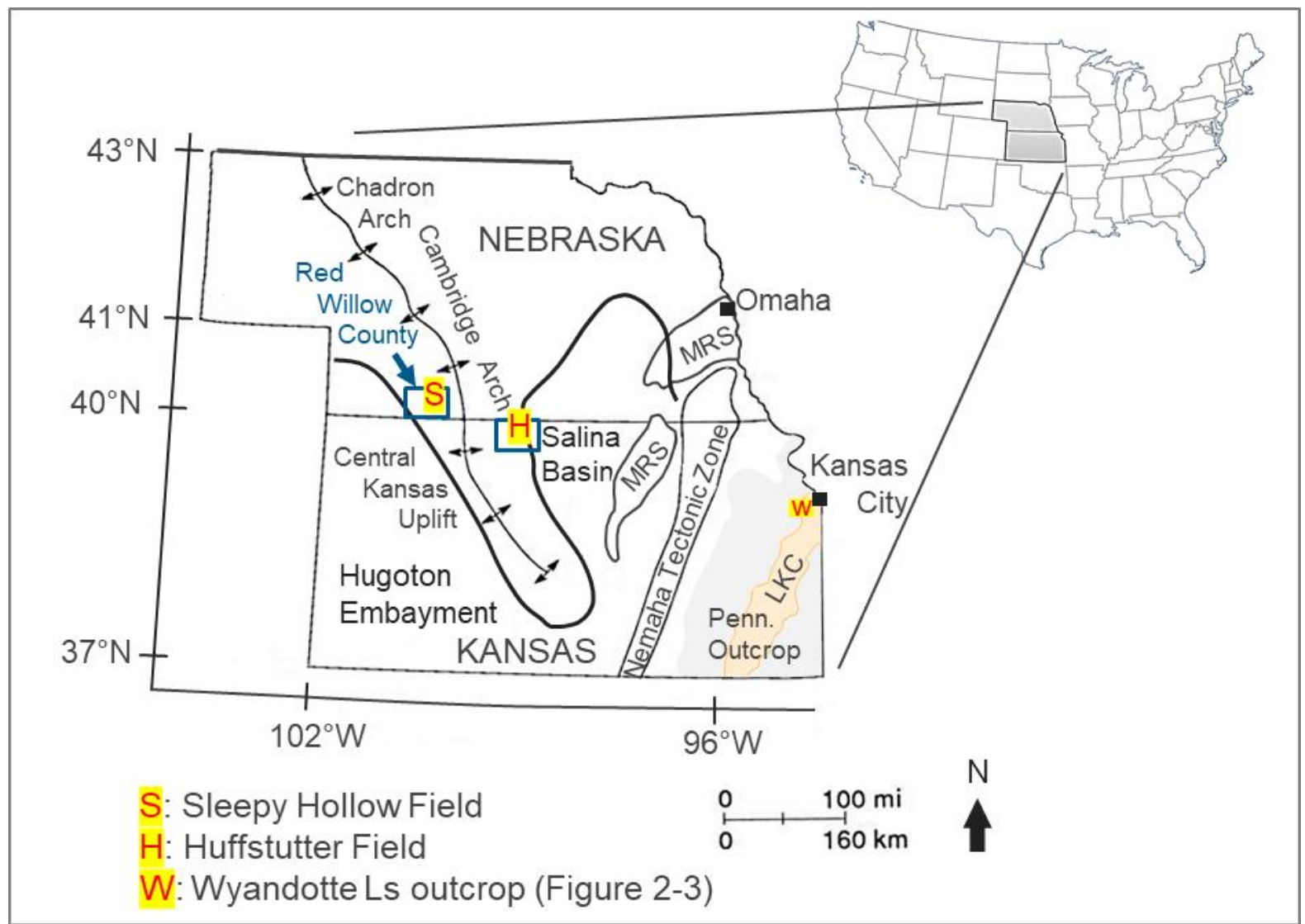

Figure 2-1. Location of Red Willow County Nebraska. The Pennsylvanian outcrops in eastern Kansas.

\section{Objective and Purpose}

The objective of this study is to reconcile the key LKC zonal lettering through correlation with their corresponding member names. The purpose of this study is to standardize LKC zone identification in southwestern Nebraska and northwestern Kansas to produce internally consistent correlations across this area. This correlation will be achieved by tracing well log signatures between the Pennsylvanian outcrop area in eastern Kansas to the Central Kansas Uplift and the Cambridge Arch area of Nebraska. 


\section{Background}

The Pennsylvanian Lansing and Kansas City Groups are two cyclic successions of interbedded limestone and shale units. These groups were deposited on a broad platform during epicontinental sea-level fluctuations associated with the Gondwana ice sheets. For subsurface interpretations, a common convention has been to pick the top of the Lansing and then the base of the Kansas City; this largely explains the lumping of these two groups as the Lansing - Kansas City (LKC) Groups. Both groups contain a series of dominant limestone members. Some of these members are oil-bearing zones in central Kansas and southwestern Nebraska. As a further simplification, operators have taken to individual lettering zones, and this practice has worked for their use in hydrocarbon exploration. Unfortunately, there are differences in the lettering convention between Nebraska and Kansas. In the geologic literature, there are many examples of where these same units have been named. Unfortunately, there are differences among earlier papers. Recognizing these issues, Heckel and Watney (2002) refined and updated the stratigraphic nomenclature for the LKC member. Still, their paper didn't explicitly address the LKC lettering conventions. This research used the Heckel (1986) "Kansas-type" cyclothem model (Figure 2-2) as a conceptual framework for facilitating the correlation of LKC members. From bottom to top, this cyclothem model begins with a lower "outside" regressive shale unit that quickly transitions into a relatively thin, transgressive limestone. This is followed by a transgressive marine "core" shale during maximum sea level, Heckel (1986). The outside and core shale terms were originally used to distinguish the terrigenous or near-shore shale from the deeper marine shale that occurs in the "core" of the cyclothem model (Figure 2-2). The offshore marine shale is followed by a thicker regressive limestone and capped by a regressive shale where the cycle begins to repeat. In southwestern Nebraska, one cycle is seldom greater than 35 feet thick. On an oilfield scale, these members are generally easy to correlate. For greater distances, like across counties, the absence of individual members is problematic for correlation due to limitations in their original thickness, or whether they were subjected to erosion during sea-level fall. In general, some portion of each cyclothem is preserved in well logs. 


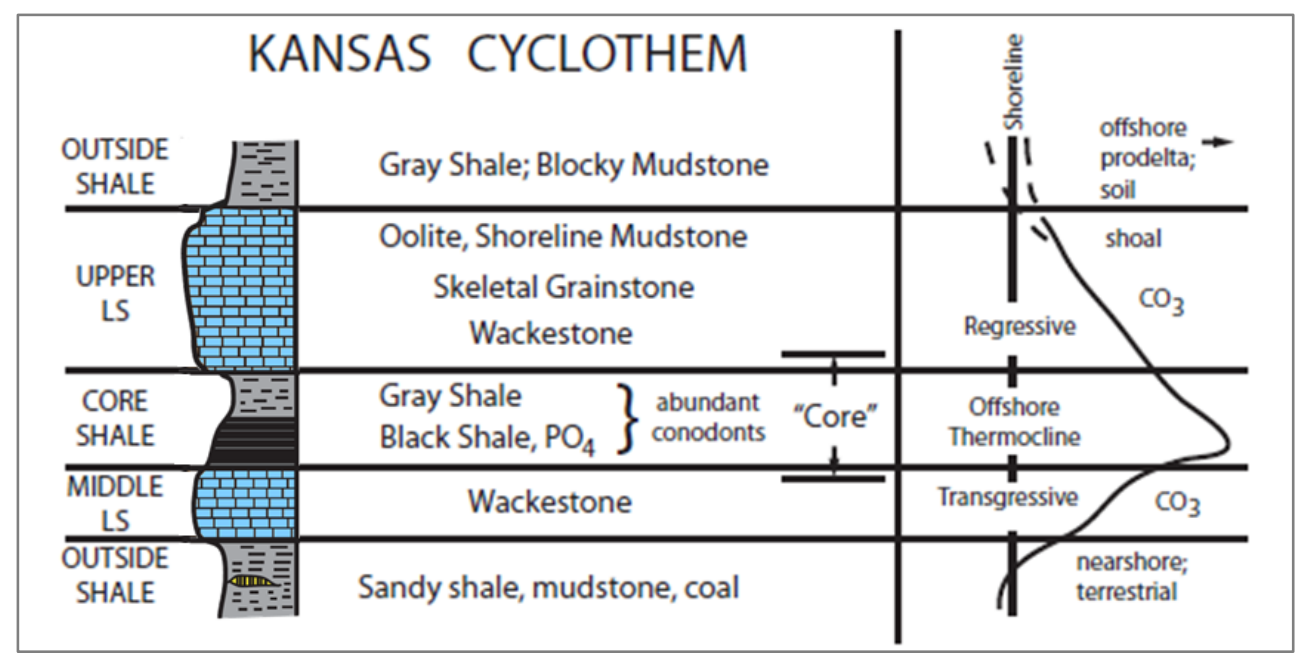

Figure 2-2. Kansas-type cyclothem, as described by Heckel (1986). Shows the transgressive-regressive cycle generally recorded in the midcontinent, and their components, the outside shales, middle and upper limestones, and the core shale that make up this type of cyclothem.

An example of a Kansas-type cyclothem is shown in outcrop from eastern Kansa (Figure 2-3). This example is from the top of the Kansas City Group and is mostly comprised of the Wyandotte Limestone and the Liberty Memorial Shale. The Wyandotte Limestone (Ls) includes three members, the transgressive Frisbie Ls Mbr., the thin transgressive Quindaro Shale Mbr., and the regressive Argentine Ls Mbr. (Figure 2-3).

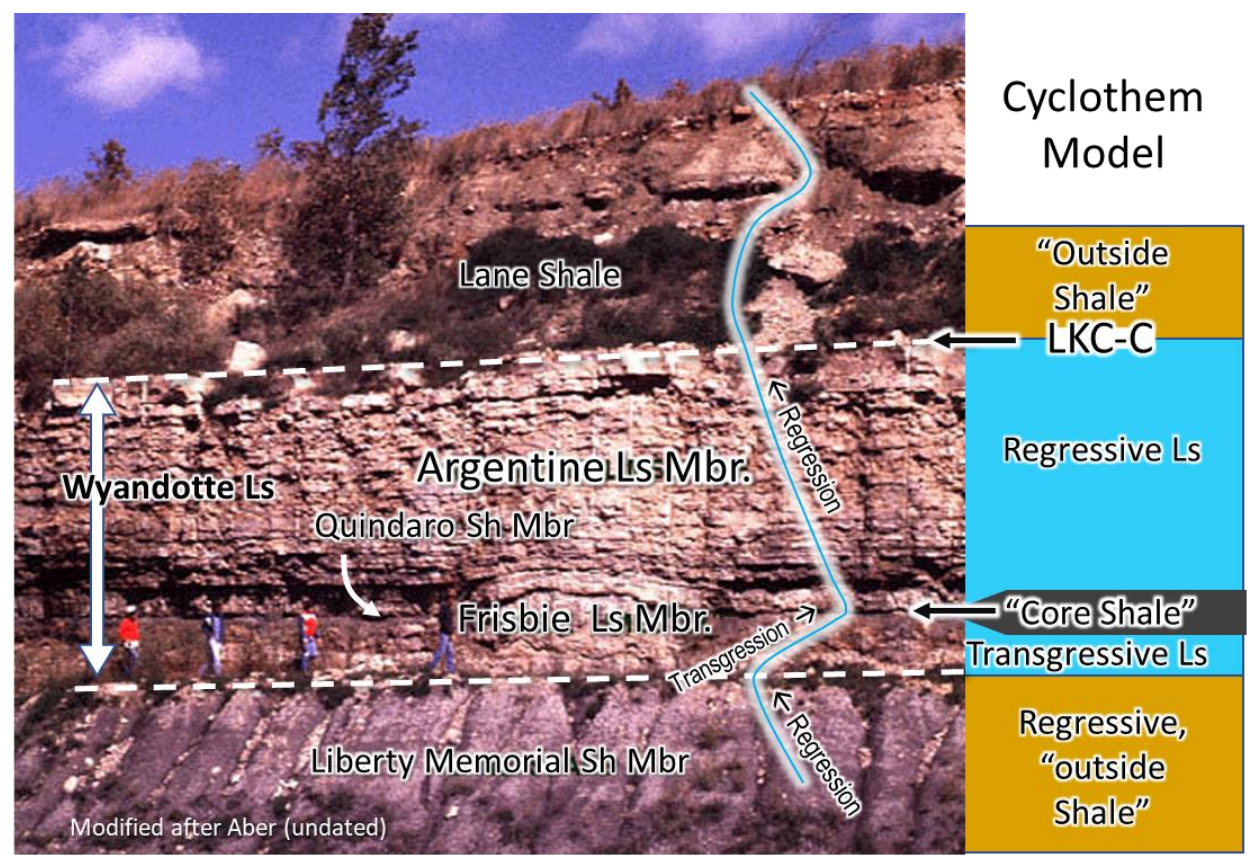

Figure 2-3. Example Kansas-type cyclothem from eastern Kansas (Kansas City area) with sea level interpretation, modified from Aber, 1985. 
To better understand the challenges of correlating the LKC in the subsurface, three examples are described below from Busch (1977), Burchett (1983), and Watney (1980).

1) Busch (1977) recognized that there were three zonal picking conventions, which he compiled from three authors (Figure 2-4). Their zonal picks are summarized below.

a) Kincaid (1961) placed zonal picks at the top of limestone units. Each zone includes an underlying "shale" unit, which is mostly comprised of the regressive shale in this example.

b) Trimble (1961) placed zonal picks by simply labeling log peaks corresponding to limestones.

c) Larson (1962) placed zonal picks by selecting the top and bottom of limestone units; adjacent shale units appear to be excluded.

The common element in all three conventions is the recognition of key limestone members; these correlate to the regressive limestone units in the Kansas-type cyclothem model. Of the three conventions, the Kincaid example has been adopted by the Nebraska Oil and Gas Conservation Commission (NOGCC). For the geomodeling work that follows in subsequent chapters, the Kincaid example was selected here to define zones for the SEM framework throughout this study. 


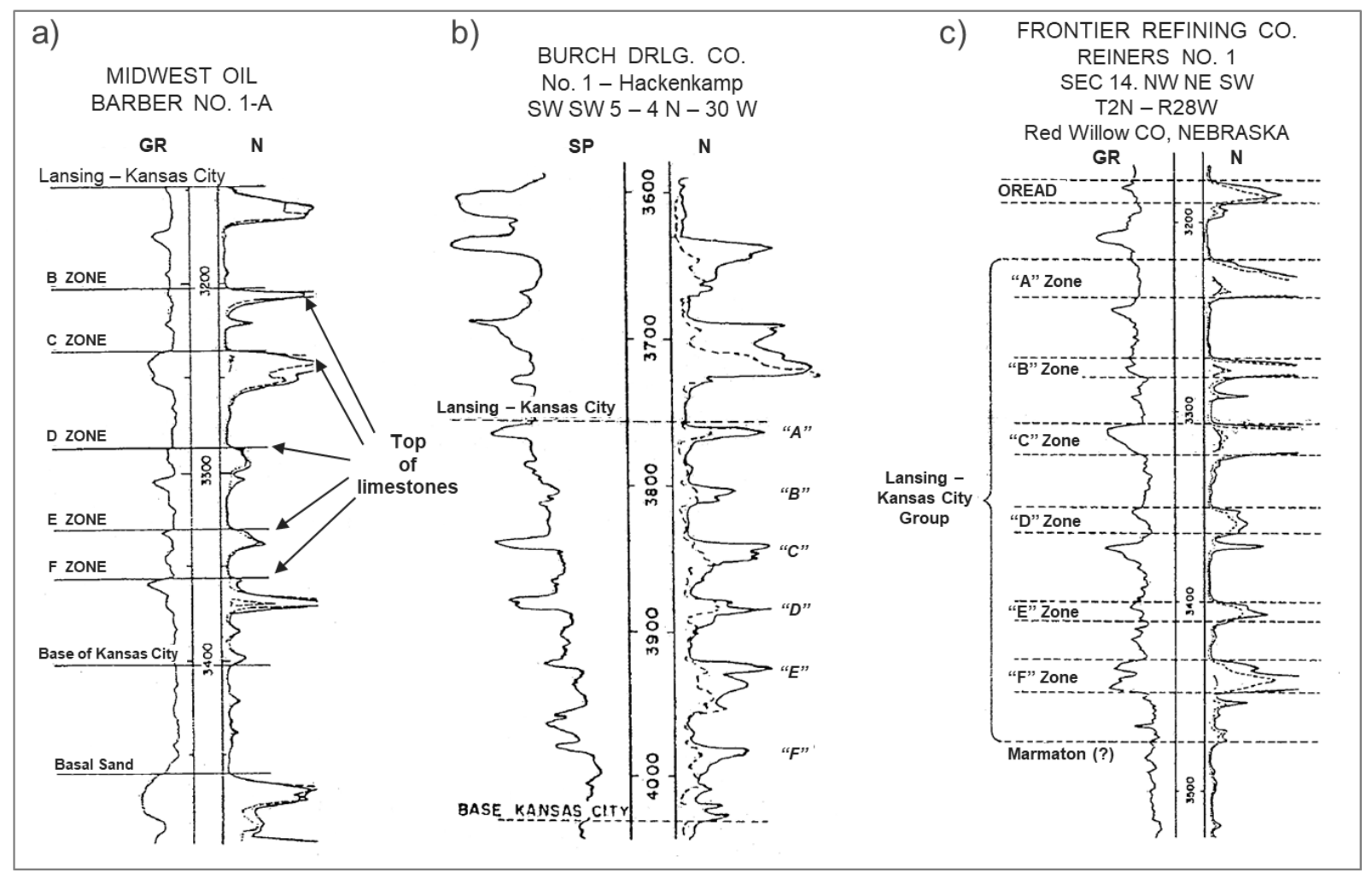

Figure 2-4. Lansing - Kansas City zonal lettering conventions based on well logs (GR=Gamma ray, SP= Spontaneous Potential, $N=$ Neutron porosity). a) Kincaid b) Trimble, and c) Larson. Modified from Busch (1977).

2) Burchett (1983) prepared an extensive well log correlation across southern Nebraska. His well section includes 32 wells with reasonable coverage across the Cambridge Arch. More importantly, Burchett's regional correlation includes member names for the LKC. He summarized his picks and included zonal lettering (Figure 2-5), which is based on the spontaneous potential and resistivity wireline logs. In his interpretation, we see a zonal picking convention like that used in the Larson (1962) example described above. The formation names represent the dominant regressive limestone members and regressive shale members. Burchett (1983) notes the absence of specific members (Figure 2-5), commonly the transgressive limestone and transgressive shale, which tend to be very thin, or pinch-out altogether in this northern portion of the Pennsylvanian epicontinental sea. Comparing Burchett's (1983) zonal lettering with Figure 2-4, we begin to see some inconsistencies that have prompted this study. For example, the zonal lettering places the "A" zone in the overlying Douglas Group above the LKC; we also see the addition of two more zones G and $\mathrm{H}$ (Figure 2-5). 


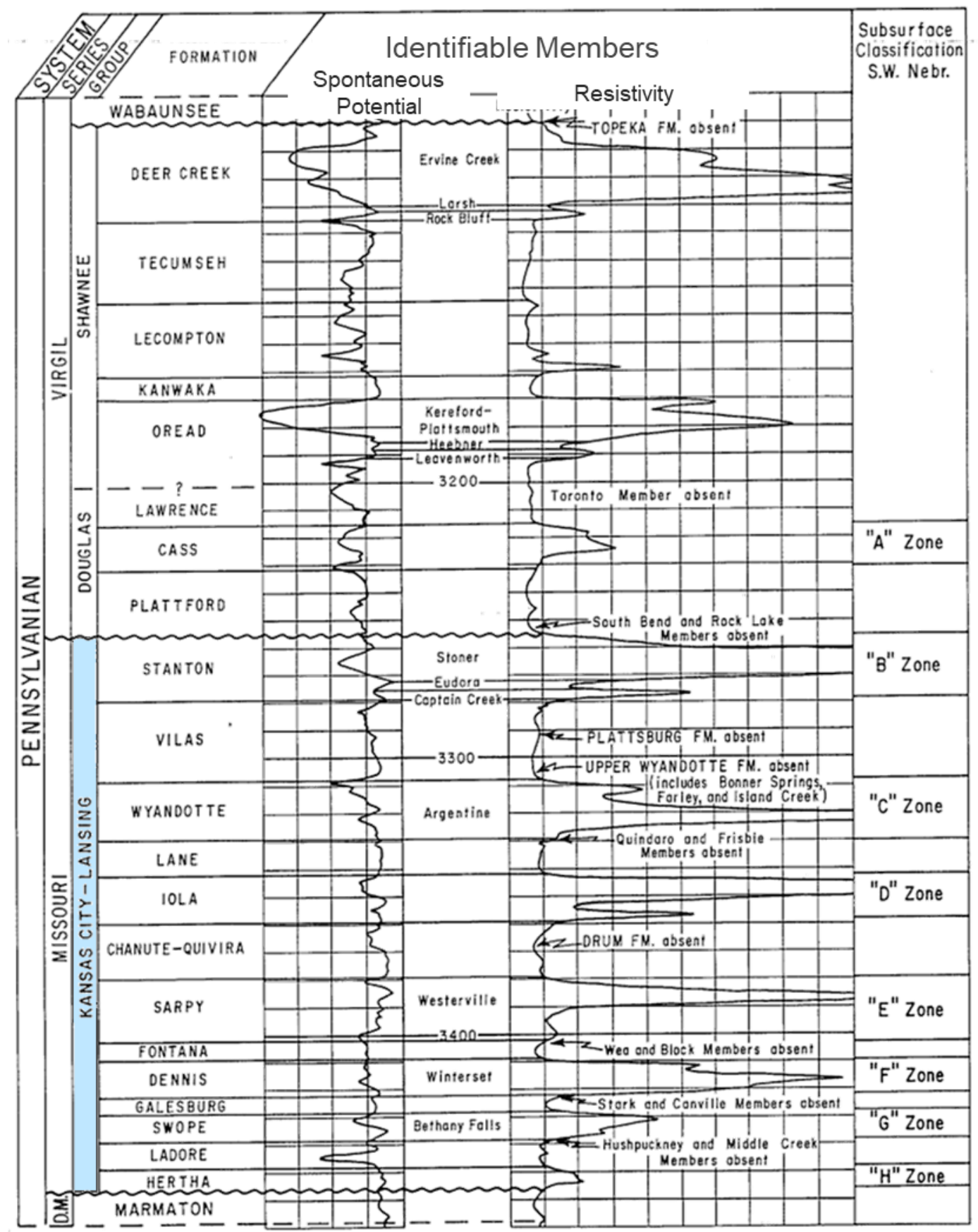

Figure 2-5. Example well logs with member interpretations by Burchett (1983). Resistivity peaks represent limestone members; these members have been labeled as zone letters " $A$ " through " $H$. ."

3) Watney (1980) conducted an extensive review of cyclic carbonates in northwestern Kansas, including Hitchcock and Red Willow Counties in Nebraska. His work involved the interpretation of 940 feet of slabbed core, well logs, and the preparation of well log correlations. An example of Watney's LKC limestone picks are shown in Figure 2-6 and are representative of the picks commonly seen and used in 
Kansas. Mainly based on gamma ray and neutron porosity logs, his pick includes zones G, H, J, and K. Note that some of the letters are absent in the A through K sequence. The zonal marking style appears similar to that used by Trimble (1961) described earlier.

In summary, these examples show that there are differences in the LKC zonal picking conventions. This study seeks to understand these differences through regional well correlation and with outcrop.

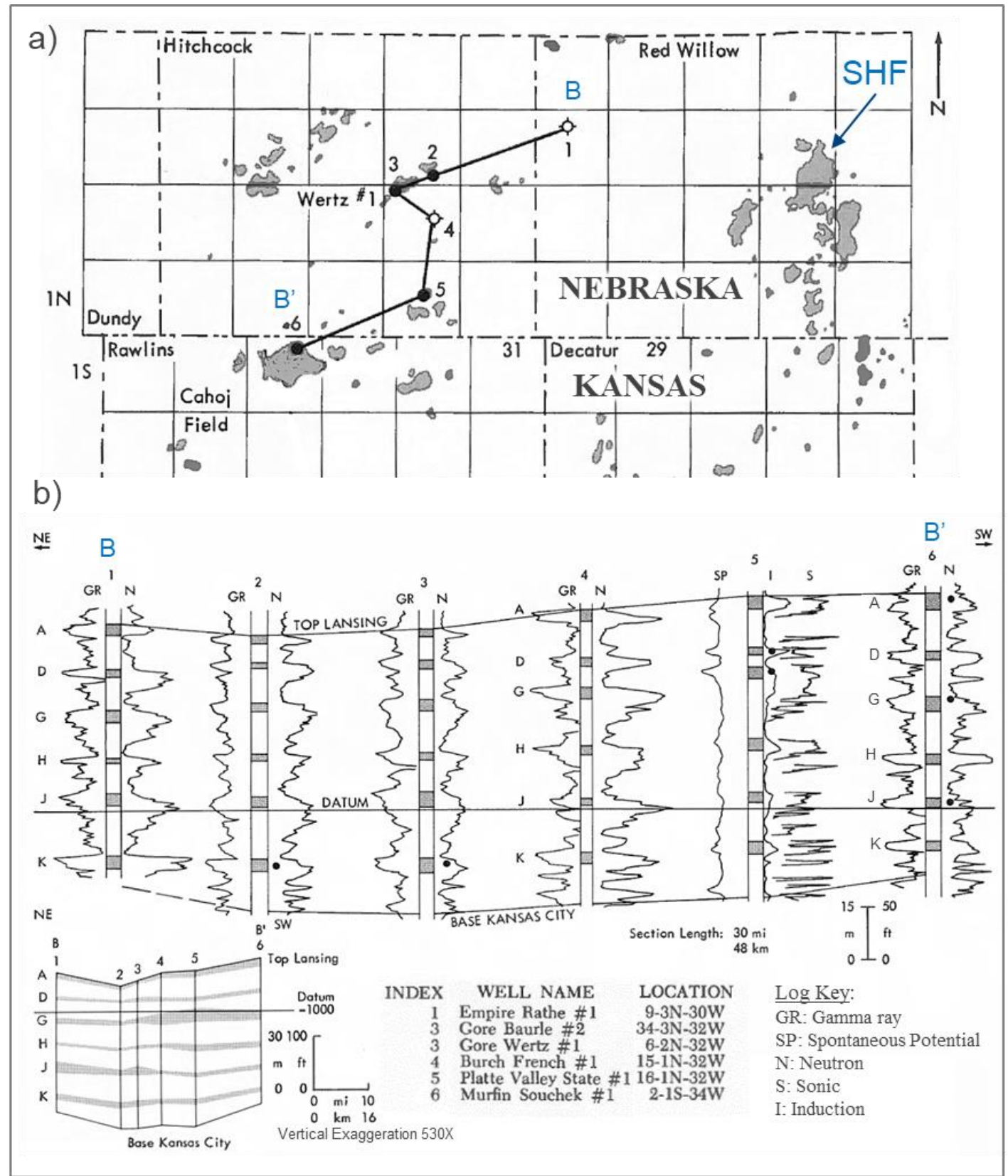

Figure 2-6. Example well section showing correlation of Lansing - Kansas City Groups, Watney (1980). a) map of well section $B-B^{\prime}$. SHF: Sleepy Hollow Field. b) Well section $B$ - $B^{\prime}$ showing picked limestone zones $A$ through $K$. 


\section{Methods}

This task was initiated using a well log-based cross-section across southwestern Nebraska to eastern Kansas; the trend of this well section is shown in Figure 2-7. The individual wells are identified in Table 2-1. Data were acquired from the Nebraska Oil and Gas Conservation Commission (NOGCC) and from the Kansas Geological Survey (KGS). The well section's route (Figure 2-7) is described below:

1) The well section line starts as close as possible to the area where the LKC outcrops in eastern Kansas.

2) The well section passes from eastern Kansas through a saddle in the Nemaha Uplift, then crosses the Salina Basin to the Dopita A-16 well on the Central Kansas Uplift. The line extends north from the Dopita A-16 well to the Huffstutter Field, and then west to Sleepy Hollow Field - both of which represent notable oil production in the area, and more recently, two areas of study for the IMSCSHub Project.

3) From there, the well section extends west off the Cambridge Arch into the Hugoton Embayment.

4) The trend of the well section was routed westward such that the structural effects of the Nemaha Uplift would have the least impact on interpreting the LKC members. The Nemaha Uplift represents a significant impediment to a clear, linear correlation of the LKC's stratigraphic units. Fortunately, unlike the Mississippian strata, the Pennsylvanian section for the LKC appears fully present over the Nemaha Uplift, and the same is true for the Central Kansas Uplift to the west (Figure 2-7).

Based on outcrop observations, the stratigraphic nomenclature revised by Heckel and Watney (2002) was used along with gamma ray logs for the correlation of LKC zones in the subsurface. We employ the "Kansas-type" cyclothem model (Heckel, 1986, 1991, 2013) as a stratigraphic model for the subsurface correlations. From this, we make a comparison of the different zonal lettering conventions used by the NOGCC and the KGS for the resulting correlations of LKC members. 


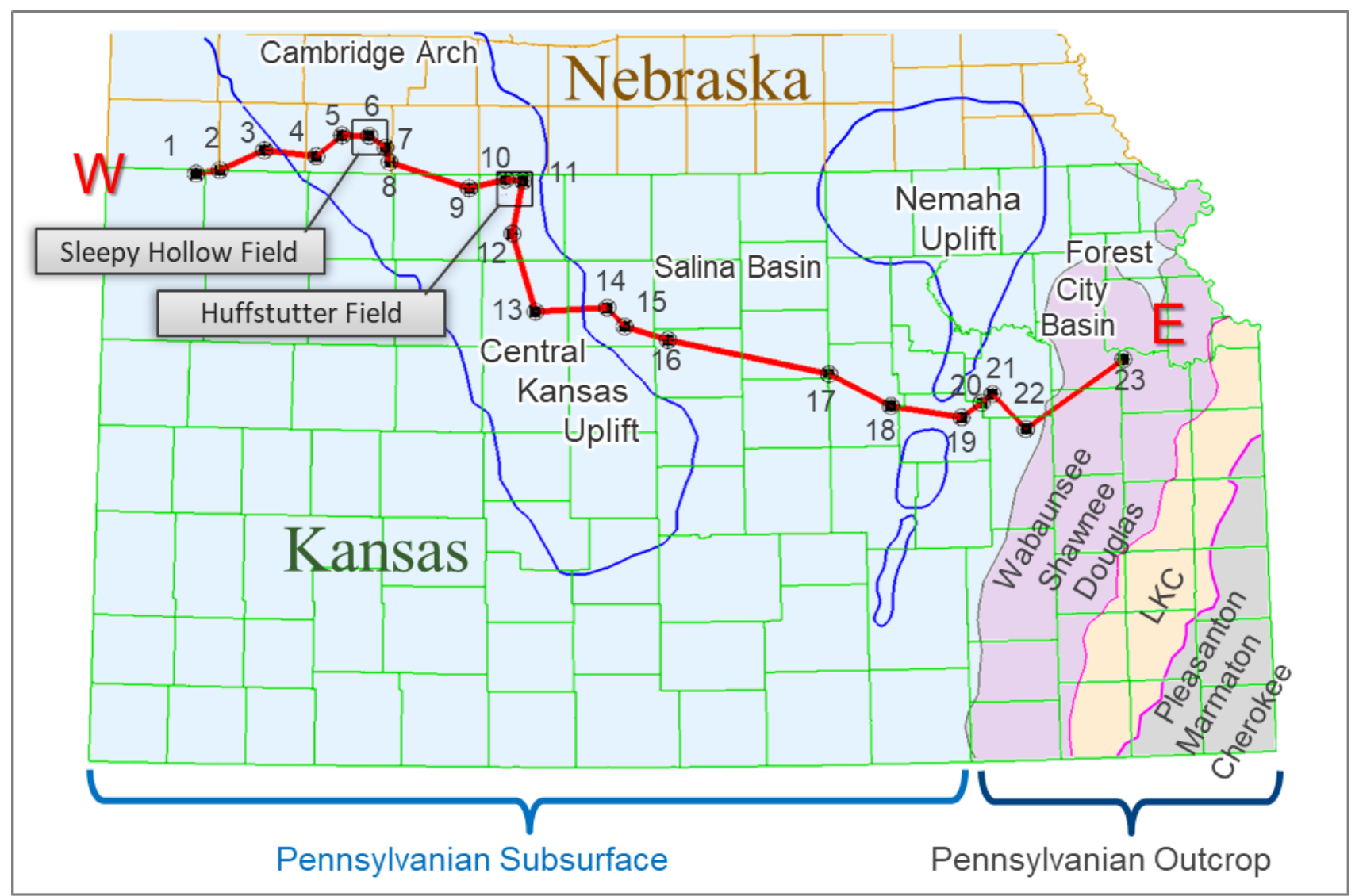

Figure 2-7. Map view of Pennsylvanian stratigraphy with well section between potential $\mathrm{CO}_{2}$ storage areas in the west and outcrops to the east. Wells are numbered west to east and are listed in Table 2-1. Cross sections are found in Figures 9, 10, and Plate 1. 
Table 2-1. Well index table for well section (Figures 2-7, 2-9 and 2-10, and Plate 1).

\begin{tabular}{|c|c|c|c|}
\hline Index & Well Name & UWI & County \\
\hline 1 & Mears 'A' 1-9 & 1502321354 & Cheyenne, KS \\
\hline 2 & Penny 14-31 & 2608722560 & Hitchcock, NE \\
\hline 3 & PATRICK 10-27 & 2608722457 & Hitchcock, NE \\
\hline 4 & ETHEL M. SUESS TRUST \#1-13 & 2614521769 & Red Willow, NE \\
\hline 5 & NORRIS 1 & 2614505583 & Red Willow, NE \\
\hline 6 & SHRU 86A (Sleepy Hollow Field) & 2614521805 & Red Willow, NE \\
\hline 7 & SAMMONS 1 & 2614505241 & Red Willow, NE \\
\hline 8 & MARVIN BOYD 1 & 2614505060 & Red Willow, NE \\
\hline 9 & Schnuerle 15-28 & 1513720368 & Norton, KS \\
\hline 10 & Kats Unit 1 & 1514720717 & Phillips, KS \\
\hline 11 & O'Neill 'A' 3 (Huffstutter Field) & 1514720105 & Phillips, KS \\
\hline 12 & Bredemeier 'B' 1 & 1514720640 & Phillips, KS \\
\hline 13 & Dopita A-16 & 1516324094 & Rooks, KS \\
\hline 14 & Schultze 'A' 1-29 & 1514120358 & Osborn, KS \\
\hline 15 & Kendig 1-32 & 1514120364 & Osborn, KS \\
\hline 16 & OETTING 1 & 1510520009 & Lincoln, KS \\
\hline 17 & Taylor 1 & 1504119007 & Dickinson, KS \\
\hline 18 & Deines 1 & 1504120080 & Dickinson, KS \\
\hline 19 & Scott 1 & 1512720440 & Morris, KS \\
\hline 20 & HEIDEMAN 1 & 1512720533 & Morris, KS \\
\hline 21 & Donna 1 & 1519720206 & Wabaunsee, KS \\
\hline 22 & HIEFNER 1-7 & 1511120425 & Lyon, KS \\
\hline 23 & $\begin{array}{l}\text { Douglas County Livestock and Fair } \\
\text { Assoc. } 1\end{array}$ & 1504520122 & Douglas, KS \\
\hline
\end{tabular}

\section{Results}

We use the revised stratigraphic nomenclature from Heckel and Watney (2002) as the basis for the subsurface correlation of LKC members in the subsurface (Figure 2-8). The named members and their traceability along the well section were mostly consistent with the Kansas-type cyclothem model by Heckel (1986) (Figure 2-2). We arrive at the member lettering conventions for Nebraska and Kansas, as shown in Figure 2-8, derived from the correlation of well logs and well tops from the NOGCC and the KGS. We summarize the correlations in Table 2-2. Plate 1 provides larger images of the LKC correlations. 


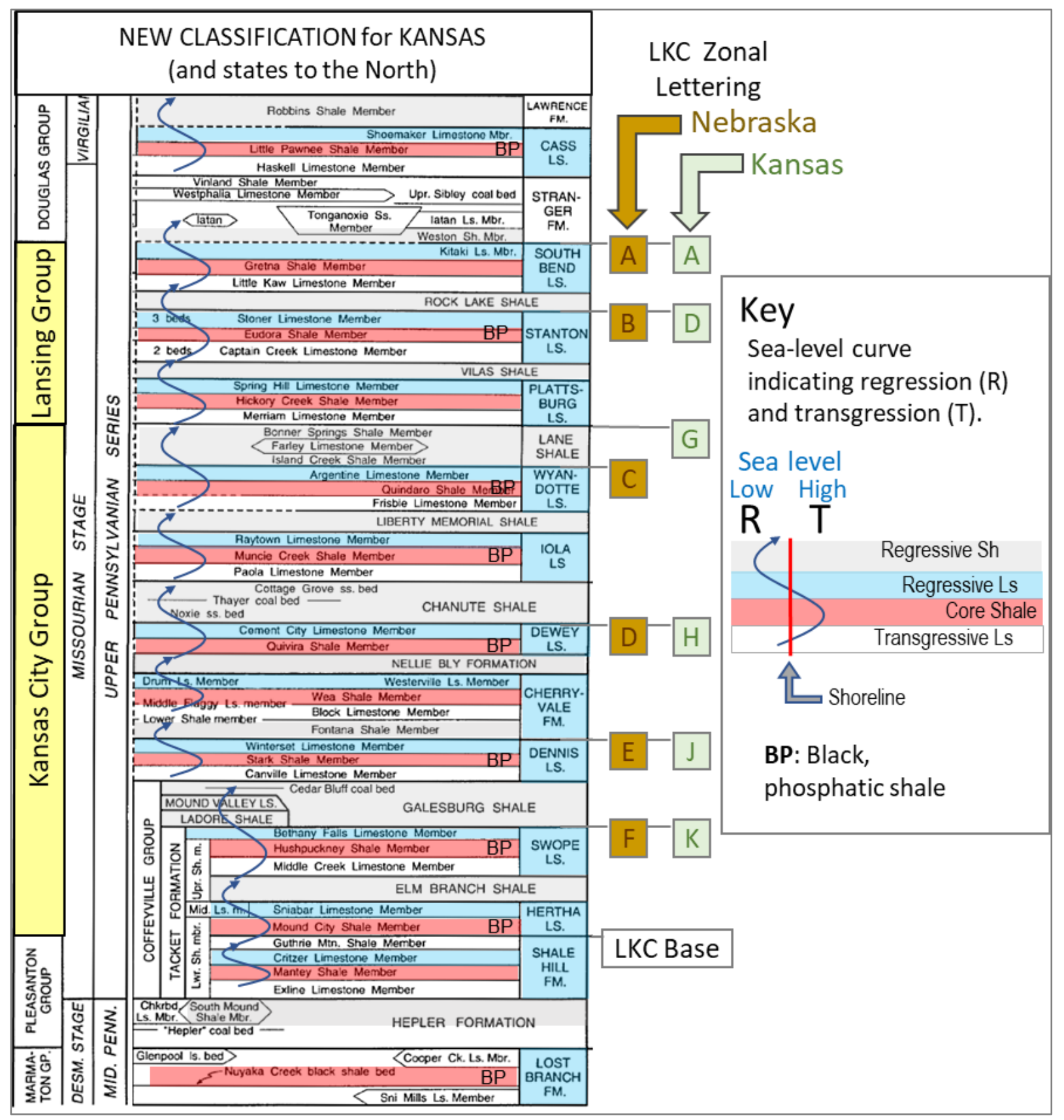

Figure 2-8. Stratigraphic nomenclature and correlative, LKC zonal letter conventions. Modified after Heckel and Watney (2002). 
Table 2-2. Summary of Pennsylvanian Lansing - Kansas City zonal-lettering conventions and their associated formation tops.

\begin{tabular}{|c|c|c|c|c|}
\hline $\begin{array}{l}\text { Nebraska } \\
\text { LKC zone }\end{array}$ & $\begin{array}{l}\text { Kansas } \\
\text { LKC Zone }\end{array}$ & LKC Member (top pick) & $\begin{array}{l}\text { Key Limestone } \\
\text { Unit(s) }\end{array}$ & Notes \\
\hline A & A & $\begin{array}{l}\text { Kitaki Limestone Mbr. } \\
\text { of the South Bend Ls }\end{array}$ & South Bend Ls & $\begin{array}{l}\text { Top of Lansing Group. A single } \\
\text { cyclothem with progressively } \\
\text { thicker Rock Lake Sh Mbr to the } \\
\text { West. }\end{array}$ \\
\hline B & D & $\begin{array}{l}\text { Stoner Limestone Mbr. } \\
\text { of the Stanton Ls }\end{array}$ & $\begin{array}{l}\text { Stanton Ls and } \\
\text { Plattsburg Ls }\end{array}$ & $\begin{array}{l}\text { Stoner Limestone Member is } \\
\text { referred to as "Lansing" in } \\
\text { NOGCC's well top database }\end{array}$ \\
\hline C & G & $\begin{array}{l}\text { C (Nebraska) is picked } \\
\text { on top of the Argentine } \\
\text { Limestone Member. }\end{array}$ & $\begin{array}{l}\text { Wyandotte Ls } \\
\text { and } \\
\text { lola Ls }\end{array}$ & $\begin{array}{l}\text { G (Kansas) is picked on top of } \\
\text { the overlying Lane Shale (top of } \\
\text { Kansas City Group) }\end{array}$ \\
\hline D & $\mathrm{H}$ & $\begin{array}{l}\text { Cement City Limestone } \\
\text { Mbr. of the Dewey Ls }\end{array}$ & $\begin{array}{l}\text { Dewey Ls and } \\
\text { Cherryvale Fm }\end{array}$ & Cement City Limestone Member \\
\hline$E$ & $\mathrm{~J}$ & $\begin{array}{l}\text { Winterset Limestone } \\
\text { Mbr. of the Dennis Ls }\end{array}$ & Dennis Ls & $\begin{array}{l}\text { A single cyclothem with high GR } \\
\text { log response for the Stark Sh } \\
\text { Mbr to the East }\end{array}$ \\
\hline $\mathrm{F}$ & K & $\begin{array}{l}\text { Bethany Falls } \\
\text { Limestone Mbr. of the } \\
\text { Swope Ls }\end{array}$ & $\begin{array}{l}\text { Swope Ls and } \\
\text { Hertha Ls }\end{array}$ & $\begin{array}{l}\text { Bethany Falls Limestone } \\
\text { Member }\end{array}$ \\
\hline LKC Base & LKC Base & $\begin{array}{l}\text { LKC Base } \\
\text { (top of Shale Hill } \\
\text { Formation) }\end{array}$ & - & $\begin{array}{l}\text { Same as the base of Mound City } \\
\text { Shale Member of the Hertha Ls }\end{array}$ \\
\hline
\end{tabular}

Based on gamma ray (GR) logs, an overview of the LKC correlation reveals key structural features across the study area (Figure 2-9). From west to east, these notable areas include the Hugoton Embayment, which has a very gentle dip to the SW. The Cambridge Arch area here includes Sleepy Hollow Field (well \#6), and the Central Kansas Uplift area includes Huffstutter Field (well \#11). Unlike the uplifted area, the Salina Basin offers a succession of formations of Mississippian age and older (Figure 2-9). The Nemaha Uplift divides the Salina Basin to the west from the Forest City Basin to the east. Lastly, the Forest City Basin offers an even thicker succession of pre-Pennsylvanian strata. Notable for this study, the Pennsylvanian section is seen climbing towards the east where it eventually crops out in the Kansas "outcrop belt" (Figure 2-7 and Figure 2-9). 


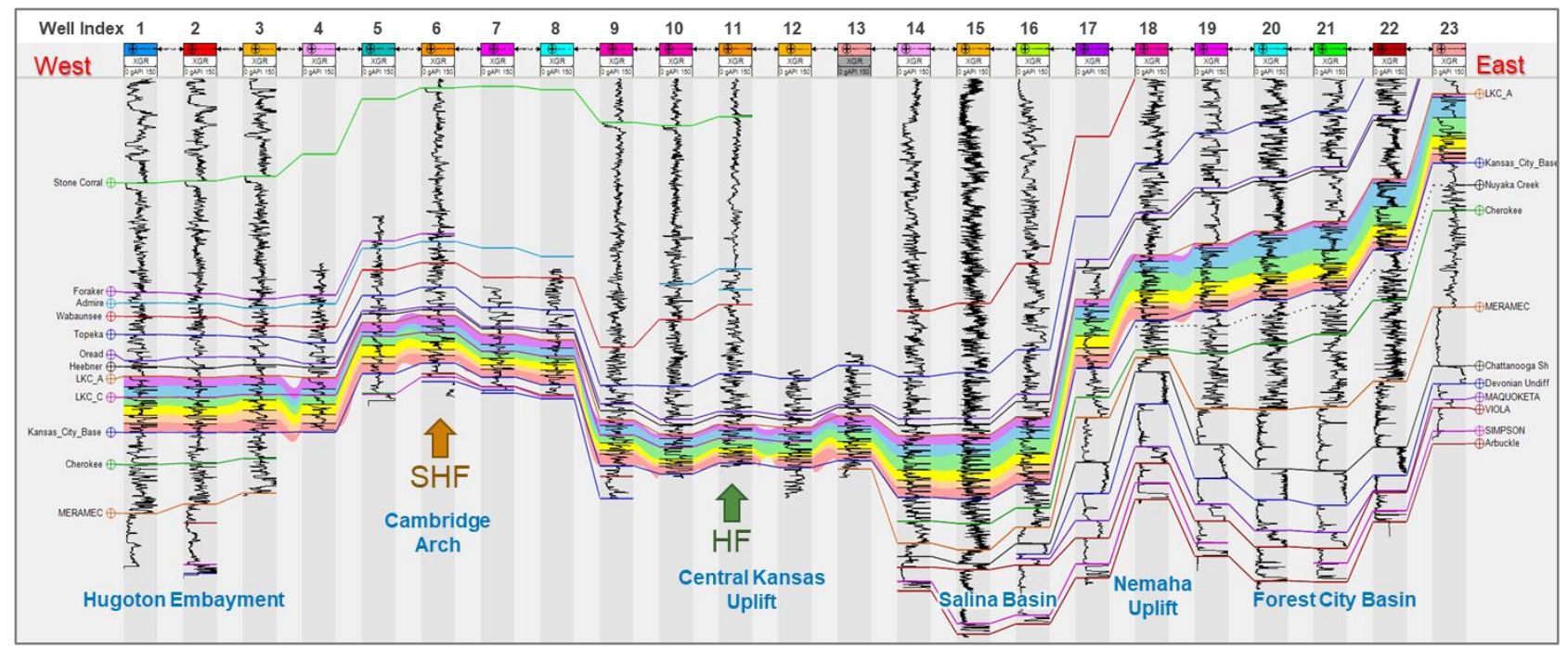

Figure 2-9. Regional subsurface well section of the Pennsylvanian Lansing - Kansas City groups reveals post depositional structural features of the LKC. Map of well section in Figure 2-7. Rainbow coloration marks six LKC zones, A through F per the Nebraska LKC zone convention. SHF =Sleepy Hollow Field. HF = Huffstutter Field.

\section{Discussion}

The primary, zonal stratigraphic picks were made on the top of carbonate units using the Nebraska “A" through "F" convention; these appear as a low gamma ray response (Figure 2-10). We use Nebraska's

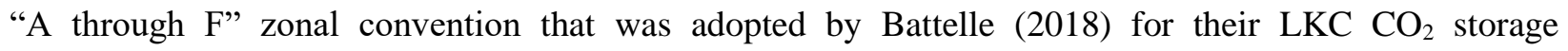
assessments. In this application, the zonal definition has been picked on the top of key regressive carbonate units and includes underlying mudrocks. All six zones (A through F) were found to be present across the well section. The GR signatures for these cyclothems reveal that there is a more substantial marine influence eastward of the Central Kansas Uplift (Figure 2-10). Evidence for this includes thicker carbonate intervals punctuated my more frequent occurrence of black "core" shales as interpreted from narrow, higheramplitude spikes on the GR logs. Wells north and west of the Central Kansas Uplift show the prevalence of thicker mudstone intervals and less pronounced or absent "core" shales. This is interpreted as a more landward position during the time of deposition. 


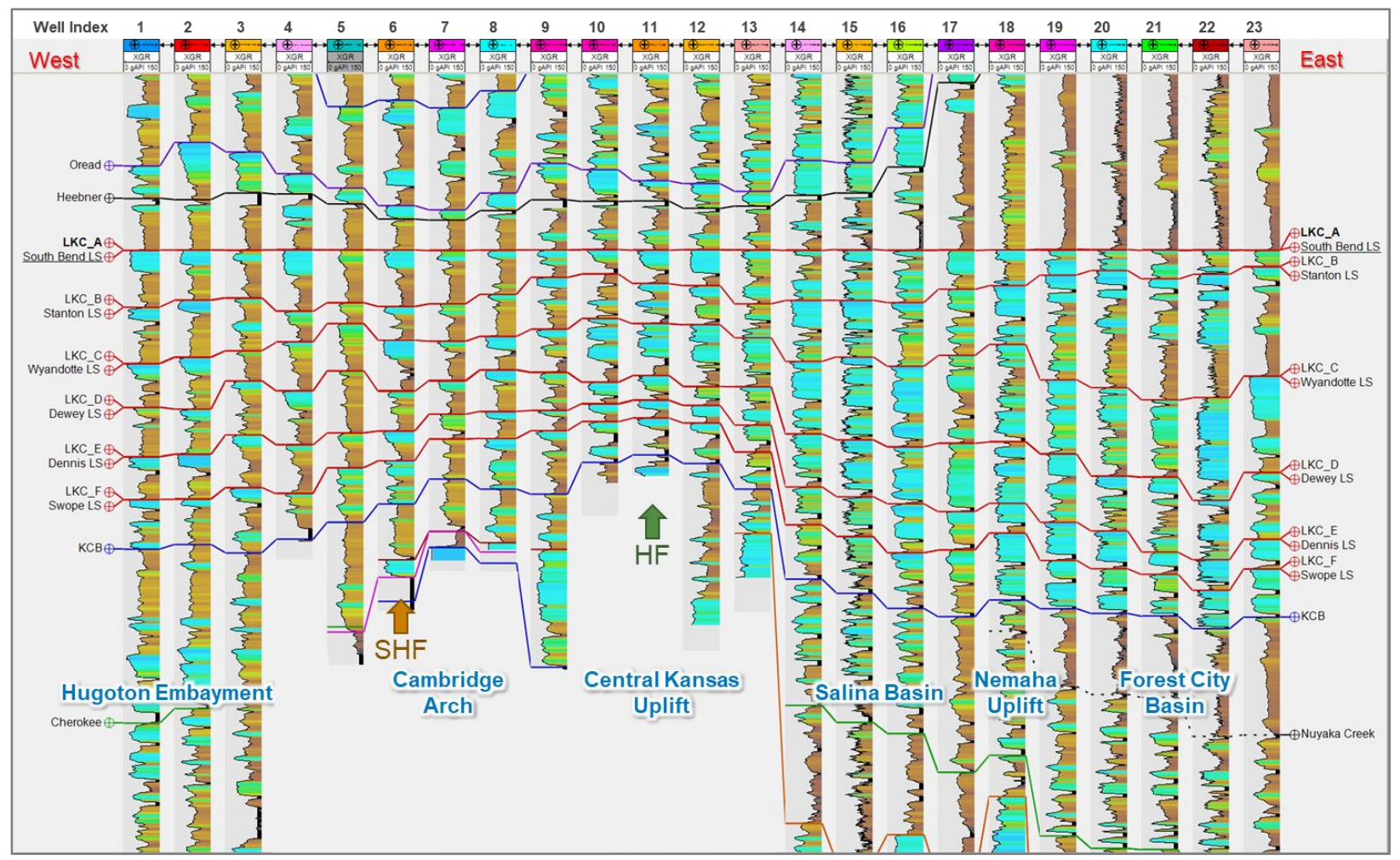

Figure 2-10. Regional well section flattened on the top of the LKC zone " $A$ " (the top of the Lansing Group). SHF: Sleepy Hollow Field. HF: Huffstutter Field. Larger image found in Plate 1.

One consequence of using the A-to-F zonal picking convention is that a second limestone mudstone pair is commonly included in the same zone. Thus, a second, recognized key cyclothem might exist within one lettered zone. Good examples of this can be seen at both Sleepy Hollow and Huffstutter Fields (well 6 and 11, respectively), where the LKC-B zone includes two clean GR log inflections (Figure 2-10 and Plate 1). With this convention, the LKC-B zone includes two cyclothems: 1) the Stanton Limestone (the regressive Stoner LS Mbr.) and 2) Plattsburg Limestone (the regressive Spring Hill LS Mbr.). Here, the transgressive limestone and transgressive shale units are either absent or are very thin and not evident in the GR response. 


\section{Summary and Conclusions}

In the midcontinent, the Pennsylvanian Lansing and Kansas City Groups represent some of the best examples of whole (complete) cyclothems, both in outcrop and in the subsurface. Nevertheless, the correlation of well logs is commonly confusing because particular members within the LKC are absent or unidentifiable in many wells. Differences in the LKC zonal lettering conventions between Nebraska and Kansas compounded this difficulty, as did changes in stratigraphic nomenclature. A well section comprised of logs and tops from the NOGCC, and KGS was prepared to reconcile the zonal picking conventions. The well section extended from southwestern Nebraska to eastern Kansas near to where the LKC crops out and has been formally studied and named. The Kansas-type cyclothem, as described by Heckel (1986) was used as a model for the subsurface correlation of LKC members along with the revised stratigraphic nomenclature from Heckel and Watney (2002).

From this study we make the following conclusions:

1) The LKC has thicker carbonate units and better developed black shales in the Salina and Forest City Basins (east of the Central Kansas Uplift).

2) The LKC thins over both the Cambridge Arch and Central Kansas Uplift, yet all LKC marine cycles are represented. Nevertheless, individual members may be absent over those structural highs.

3) Regressive mudstone units in the LKC thicken on the Cambridge Arch, but black shales are uncommon and change the gamma ray log expression of cyclothems relative to the outcrop-based model.

4) The NOGCC well tops database refers to and includes both "LKC-B" and "Lansing." These picks are synonymous, and the LKC-A overlies them. Thus, the NOGCC's "Lansing" top is not the actual Lansing Group top as recognized by the revised stratigraphic nomenclature from Heckel and Watney (2002). 
5) The base of the LKC is the base of the Mound City Shale Member of the Hertha Limestone.

6) The Muncie Creek Shale Member of the Iola Limestone is one of the more laterally extensive and recognizable units along the length of the well section.

7) In Nebraska, LKC-C is picked on top of the Argentine Limestone Member. In Kansas, G is the top of the Lane Shale and marks the top of the Kansas City Group.

Ongoing research involves expanding LKC member correlations into the northern portion of the Salina Basin (central Nebraska Basin) and validating well log signatures through core samples. This research supports the Integrated Midcontinent Stacked Carbon Storage (IMSCS) Hub project, and as of 2019, impacts the development of commercial $\mathrm{CO}_{2}$ storage interests in the area. 


\section{Acknowledgments}

The research for the Integrated Mid-continent Stacked Carbon Storage Hub (IMSCS HUB) project is supported by the U.S. Department of Energy - National Energy Technology Laboratory Agreement No. DE-FOA-0031623 and No. DE-FE0029264. The data supplied in this study were acquired in collaboration with the Conservation and Survey Division, School of Natural Resources, University of Nebraska-Lincoln, and through Great Plains Energy, Inc., Lincoln, NE. Existing oilfield data was acquired through the Nebraska Oil and Gas Commission and the Kansas Geological Survey Oil and Gas database.

\section{References}

Battelle Memorial Institute, 2018, Integrated Mid-Continent Stacked Carbon Storage Hub, Task 3 SubBasinal Geologic Assessment Topical Report, DOE Agreement/Project \# DE-FE0029264.

[ https://www.osti.gov/biblio/1478726-integrated-mid-continent-stacked-carbon-storage-hub-phase-final-report ]

Aber, J., undated, Bedrock Geology of the Kansas City Vicinity

[http://www.geospectra.net/lewis_cl/geology/bedrock.htm].

Burchett, R.R., 1983, Surface to Subsurface Correlation of Pennsylvanian and Lower Permian Rocks Across Southern Nebraska, Nebraska Geology Survey, Report of Investigation \#8.

Busch, K., 1977, Structure and Stratigraphy of the B Zone (Lansing- Kansas City Groups) in Red Wilow County, Nebraska, Masters Thesis, University of Nebraska at Lincoln.

Heckel, P. H., 1986, Sea-level curve for Pennsylvania eustatic marine transgressive-regressive depositional cycles along midcontinent outcrop belt, North America: Geology, v. 14, p. 330-334.

Heckel, P. H., 1991, Thin widespread Pennsylvanian black shales of the Midcontinent North America: a record of cyclic succession of widespread pycnoclines in a fluctuating epeiric sea: Geological Society Special Publication, no 58, p. 259-273.

Heckel, P. H., and Watney, W. L., 2002, Revision of Stratigraphic Nomenclature and Classification of the Pleasanton, Kansas City, Lansing, and Lower Part of the Douglas Groups (Lower Upper Pennsylvanian, Missourian) in Kansas: Kansas Geological Survey Bulletin 246.

Heckel, P. H., 2013, Pennsylvanian stratigraphy of Northern Midcontinent Shelf and biostratigraphic correlation of cyclothems, Stratigraphy, v.10, p. 3-39.

Kincaid, 1961, RMAG Colorado-Nebraska Oil and Gas Field, V. RMAG, 1961, p. 325.

Larson, W.G., 1962, Ackman Field and Environments, Southwestern Nebraska: AAPG Bulletin V26., No. 11, pp. 2079-2089.

Trimble, 1961, RMAG Colorado-Nebraska Oil and Gas Field, V. RMAG, 1961, p. 305.

Watney, W.L, 1980, Cyclic sedimentation of the Lansing-Kansas City Groups in northwestern Kansas and southwestern Nebraska: Kansas Geological Survey, Bulletin 220. 


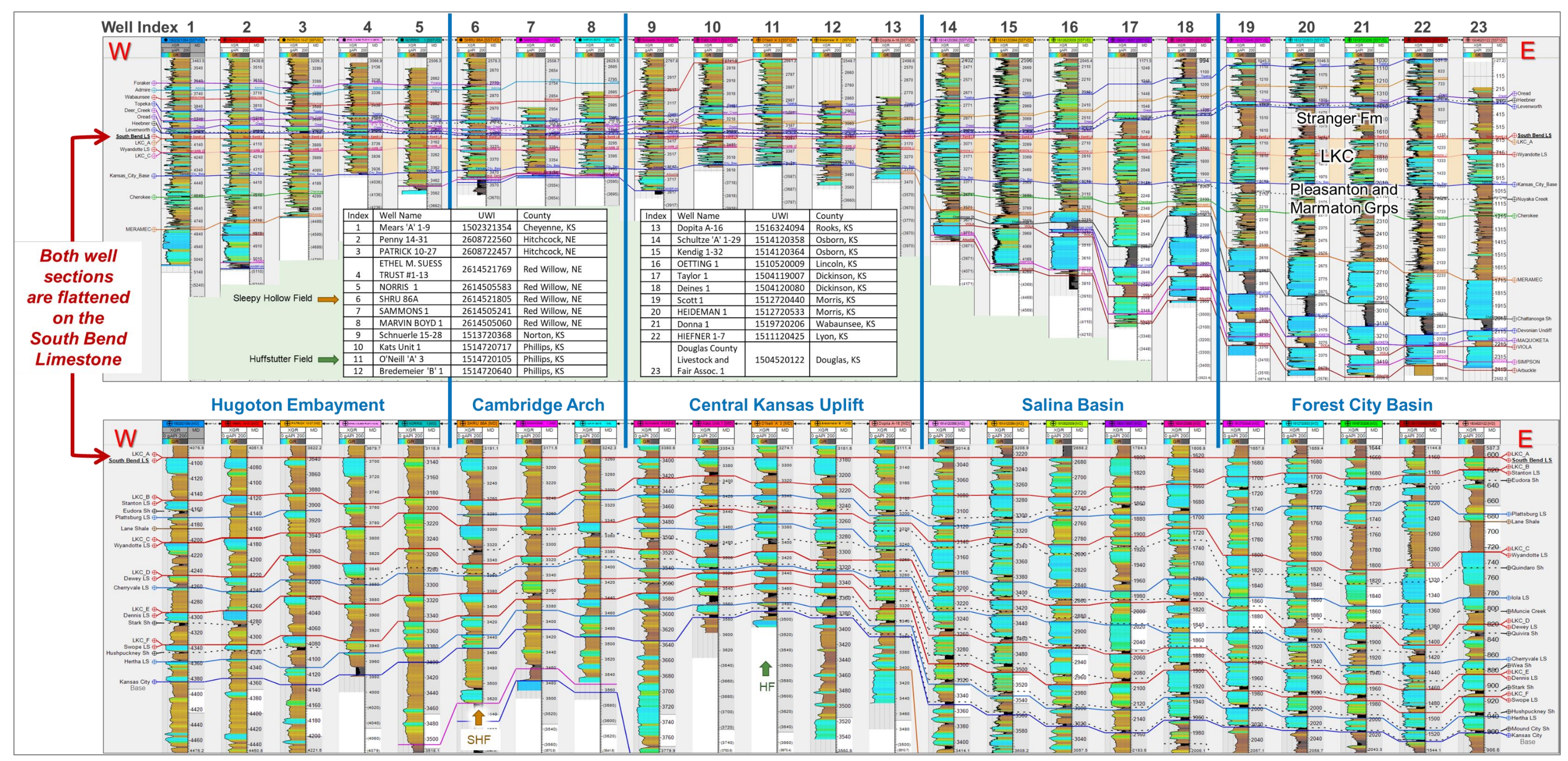

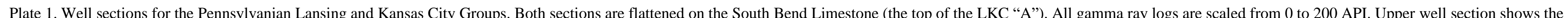

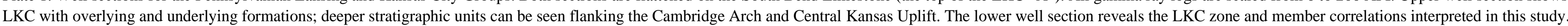




\title{
Chapter 3: Reservoir Characterization and Static Earth Model for Potential $\mathrm{CO}_{2}$ Storage in Upper Pennsylvanian Cyclothems, Nebraska, USA ${ }^{1}$
}

\begin{abstract}
This study estimates the carbon storage potential of interbedded shales and carbonate rocks (cyclothems) in the Pennsylvanian Lansing and Kansas City Groups (LKC) on the Cambridge Arch in southwestern Nebraska, USA. This effort is essential to the development of a $\mathrm{CO}_{2}$ storage strategy for the Integrated Midcontinent Stacked Carbon Storage (IMSCS) Hub Project as part of DOE-NETL's Carbon Storage Assurance Facility Enterprise (CarbonSAFE) initiative.

We present a static earth model (SEM) representing the $\sim 250$-foot-thick $(76.2 \mathrm{~m}) \mathrm{LKC}$. This model is based on vintage (mostly pre-1970) well logs from the Sleepy Hollow Field (Red Willow County, Nebraska) as well as a new (June 2019) stratigraphic test well (SHRU 86A) drilled expressly for the purpose of the present study. Interpretations of advanced petrophysical logs and cores from this new well were essential for the development of the SEM geologic framework.

Gamma ray logs readily differentiate carbonate and mudstone units within the $\mathrm{LKC}$, allowing the differentiation of three facies for use in a facies model. We used gamma ray facies to correlate carbonate rock units comprised of multiple textures, across the field. We model heterogeneity within these carbonate units using effective porosity logs. Properties were interpolated using a Gaussian Random Function Simulation conditioned by the 3D facies model. We used the resulting SEM to compute carbon-storage estimates for each LKC carbonate zone over an area of 1 square mile. In total, supercritical $\mathrm{CO}_{2}$ storage in the LKC is estimated at 602,157 tonnes/ mile ${ }^{2}\left(232,494\right.$ tonnes/ $\left.\mathrm{km}^{2}\right)$ when using a saline storage efficiency factor of 0.1 for carbonates from Peck et al. (2014).
\end{abstract}

\footnotetext{
${ }^{1}$ Smith, V.L., Joeckel, R.M., 2020, Reservoir Characterization and Static Earth Model for Potential $\mathrm{CO}_{2}$ Storage in Upper Pennsy/vanian Cyclothems, Nebraska, Environmental Geosciences, v. 27, no. 2
} 


\section{Introduction}

The Integrated Midcontinent Stacked Carbon Storage (IMSCS) Hub Project is part of DOENETL's Carbon Storage Assurance Facility Enterprise (CarbonSAFE) initiative. This project seeks to develop a regional carbon-storage hub or corridor connecting sources of captured carbon to existing oilfields for carbon storage and enhanced oil recovery (EOR). This research supports the assessment of geologic $\mathrm{CO}_{2}$ storage for sites in Nebraska and Kansas. The project began with the analysis of a study area in southwestern Nebraska centered on Sleepy Hollow Field (Figure 3-1). This site was selected because the potential reservoir units and seals in the Lansing and Kansas City groups (LKC) were determined to be of sufficient depth and quality for supercritical $\mathrm{CO}_{2}$ storage. Limestones and mudrocks dominate the LKC, and it has long been interpreted as a succession of "Kansas-type" cyclothems, e.g., (Heckel, 1986; Heckel, 1999). Our analyses of trends in gamma-ray (GR) and neutron-porosity (NPHI) logs, as well as new data generated in the course of this study, reinforces the longstanding hypothesis that the LKC was deposited under conditions of fluctuating eustatic sea level (Heckel, 1986).

Although the common $\mathrm{CO}_{2}$ storage concept is comprised of a distinctive reservoir and seal pair, the storage assessment for the LKC is complicated by the stacking of reservoirs and seals, some of which are hydrocarbon-bearing. A successful storage strategy for the LKC group depends on a detailed understanding of the development and occurrence of porosity in carbonate strata.

Reservoir characterization began with the compilation of vintage (mostly pre-1970s) well logs from the study area. Existing subsurface interpretations of the LKC (Dubois, 1985; Watney, 1980) from nearby oilfields were also incorporated in the characterization of potential storage units. Subsurface interpretation and reservoir characterization provided the basis for a static earth model (SEM) representing the LKC. SEM refers here to the dimensional (3D) geocellular model that contains petrophysical properties describing the reservoirs and seals. Existing core samples from Sleepy Hollow and neighboring oilfields show that porosity exists primarily in packstone and grainstone units. 
Observations from cores and logs demonstrate that LKC strata can be subdivided into limestonedominated, mudstone-dominated, and shale-dominated packages of strata, with further examples below. Gamma ray log thresholds, which represent important differences in reservoir (or seal) quality, were used to quantitatively define these three packages of strata as GR log facies. Neutron Porosity (NPHI) logs were used during the 3D petrophysical property modeling; however, they were a poor indicator of effective porosity due to the clay-bound water that is commonly present within mudrocks. NPHI log responses to clay-bound water complicated the derivation of effective porosity logs and, therefore, posed a substantive problem in this project. This problem was resolved through comparative analysis using core samples.

\section{Objective and Purpose}

The objective of this reseach is to characterize the reservoirs and seals within the LKC group at Sleepy Hollow Field. The LKC represents both saline and hydrocabon units throughout the area. The purpose of this work is twofold: 1) develop a 3D, Static Earth Model representing the petrophysical propertiest of these units so that, 2) a quantitative $\mathrm{CO}_{2}$ storage assessment can be performed on the reservoir units

\section{Geologic Setting}

Red Willow County (Figure 3-1a) has numerous oilfields originating in the early 1960's (Busch, 1977). Maps of formation tops in these oilfields show the Cambridge Arch (Moore and Nelson, 1974) as a northwesterly continuation of the Central Kansas Uplift. Together, these structural uplifts trend from the northwest to the southeast (Figure 3-1a). Sleepy Hollow Field (SHF), the primary study area for this storage project, is a very gentle anticline located on the southwestern portion of the Cambridge Arch. SHF contains more than 200 wells, some of which penetrated weathered basement rocks (Figure 3-1b). Oil production for SHF has been from the LKC stratigraphic zone "C," as well as from a thin sandstone that directly overlies the basement rock (Rodgers, 1977) (Figure 3-2). This basal sandstone is locally referred to as the "Sleepy Hollow sandstone," and it is also labeled as the oil-producing "Reagan Unit" in some logs. It remains unclear, however, whether this sandstone is indeed equivalent to and of the same age as the 
regionally extensive Reagan Sandstone (Cambrian), or whether it is a localized, basal Pennsylvanian deposit.

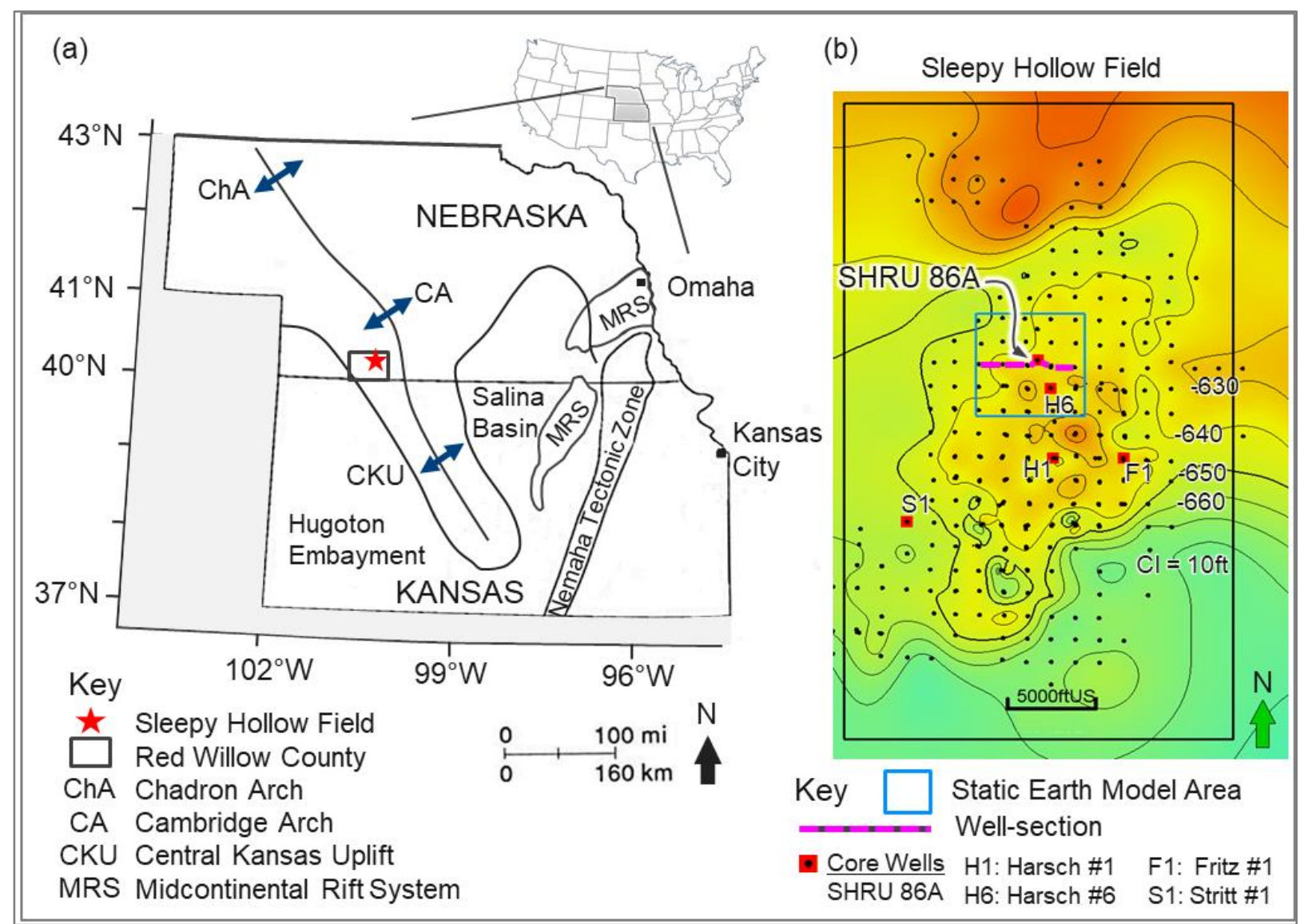

Figure 3-1. (a) Location of Sleepy Hollow Field on the southwestward limb of the Cambridge Arch in Nebraska (modified after Steeples, 1982). (b) Sleepy Hollow Field study area outlined by a black rectangle. Well coverage is shown as black dots. Red boxes: wells with core samples. Pink line: well section. The blue box represents the footprint of SEM reported in this paper. Contours are elevation depth (feet, mean sea level) for the top of the LKC.

The preliminary target reservoirs for $\mathrm{CO}_{2}$ sequestration are stacked carbonate rocks in the Pennsylvanian system, which are the same limestone strata that may produce petroleum (Figure 3-2). The aforementioned basal sandstone is also considered a potential reservoir for carbon storage. The Pennsylvanian system is dominated by cyclic packages of carbonates and mudrocks, the origins of which are attributed to glacioeustatic sea-level fluctuations in shallow seas on an epicontinental platform. The characterization of these carbonates and their representation in an SEM is the central theme of this paper. 
Caprock intervals in the study area are also cyclically stacked and consist of a series of tighter, mudrock units that separate the comparatively porous carbonate intervals. The deeper, basal sand unit is also overlain by mudrocks in the Pleasanton and Marmaton groups underlying the LKC (Figure 3-2). The basic well log suite for many of the wells in the Sleepy Hollow Field (Figure 3-1b) includes gamma ray (GR), neutronporosity (NPHI), and resistivity (R) logs; there are cored intervals in a few $(\sim 18)$ of these wells.

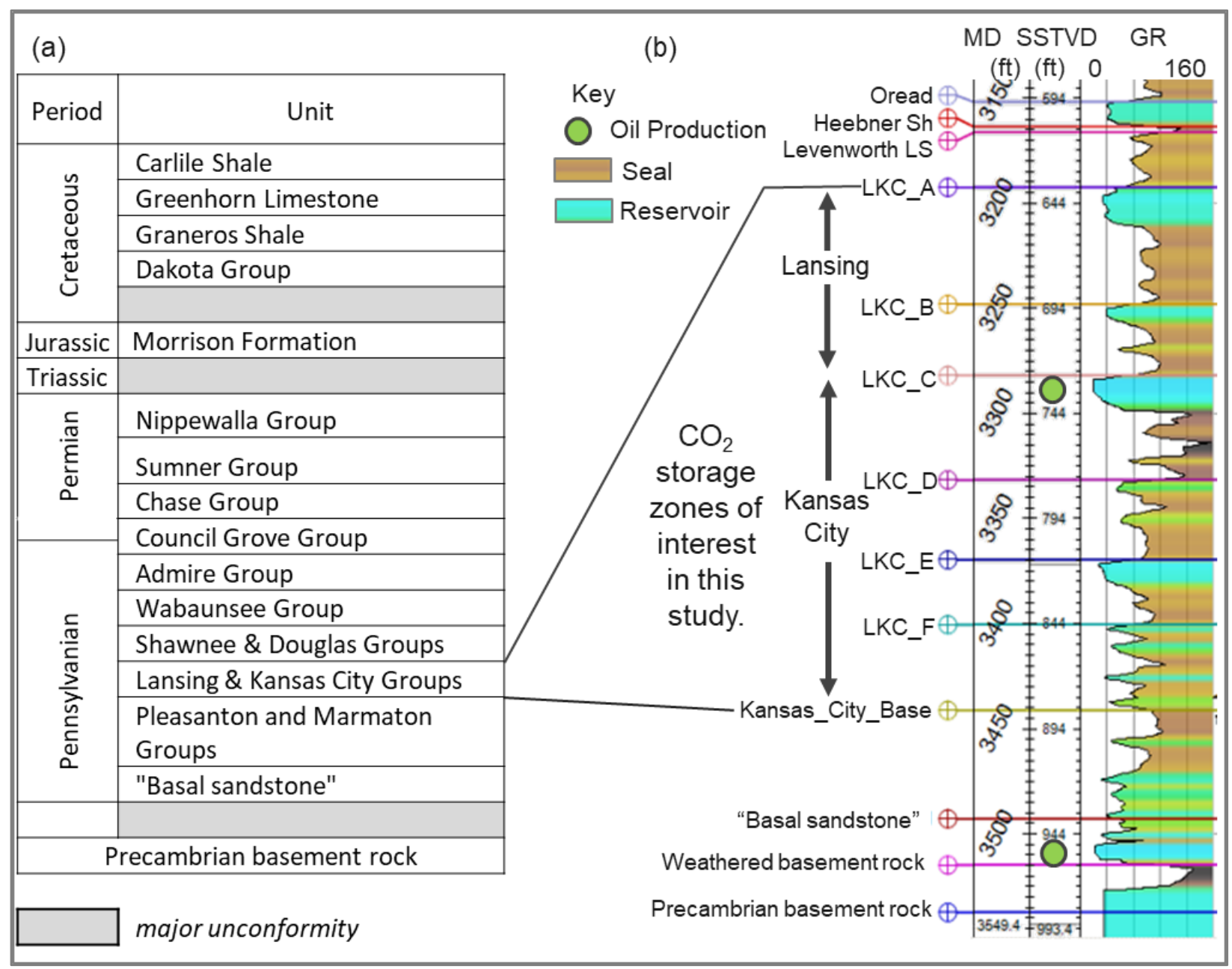

Figure 3-2. (a) Simplified stratigraphic column showing the deep saline formations of interest and overlying caprocks evaluated in the Cambridge Arch study area. (b) Example of gamma ray (GR) log response for the Lansing and Kansas City Groups where members are commonly lettered A through F.

An example of the carbonates' cyclicity is shown in (Figure 3-3) from wells central to the Sleepy Hollow Field that were drilled to approximately 3,520 ft (1,073 m). The total depth of the new SHRU 86A well is 3,636 ft (1,108 m). At an approximate depth of 3,150 ft $(960 \mathrm{~m})$ and thickness of $\sim 250 \mathrm{ft}(+5 \mathrm{ft},-7$ 
ft) $(\sim 76.2 \mathrm{~m}(+1.5 \mathrm{~m},-2.1 \mathrm{~m}))$, the LKC has been subdivided by well drillers into the lettered stratigraphic zones (“A” through "F") in southwestern Nebraska. However, conventions for lettering LKC stratigraphic zones are different in Nebraska and Kansas, potentially adding an element of confusion to the interpretation of the succession.

The preceding chapter (Chapter 2) discussed the specifics regarding the lettering conventions. The LKC's lettered stratigraphic zones range in thickness from $28 \mathrm{ft}$ to $64 \mathrm{ft}(8.5 \mathrm{~m}$ to $19.5 \mathrm{~m})$. Each zone is comprised of carbonates (oolitic, peloidal, and skeletal grainstones, plus other, less porous textures) and mudrocks (mudstones and shales). Some of these lithologies are tight; therefore, each carbonate zone has storage restrictions determined by the magnitude and stratigraphic distribution of porosity. The top of weathered basement rock is penetrated at approximately 3,550 feet $(1,082 \mathrm{~m}$ ) measured depth MD (Figure 3-3). The interpreted base of the LKC (commonly labeled the "Kansas City Base") is also the undifferentiated top of either the Pleasanton or Marmaton Groups. 


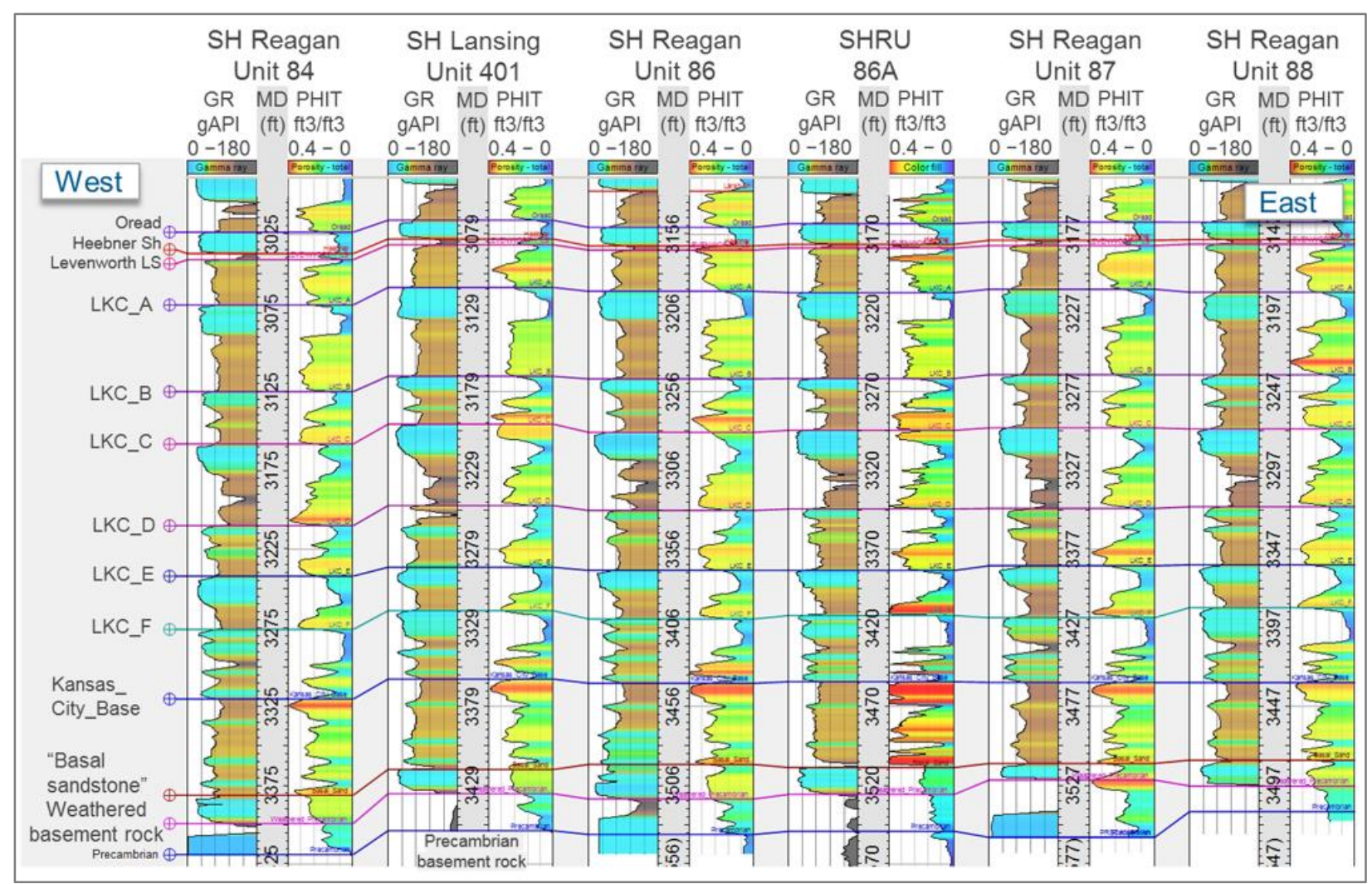

Figure 3-3. Gamma ray (GR) and total porosity logs (PHIT) for six wells fully penetrating the LKC section. The repetitive patterns in these logs are representative of the cyclicity of these carbonates and mudrocks. $L K C$ zones are picked on top of key carbonate units. See Figure 1 b for well section location.

The geologic structure in the Sleepy Hollow Field has been determined primarily by mapping formation tops in the absence of seismic surveys. Structural mapping of formation tops, such as the top of the LKC, reveals a gentle anticlinal structure in the study area (Figure 3-1b). Although the LKC is considered the primary storage section, a thin sandstone at the base of Phanerozoic sedimentary-rock cover (the "Sleepy Hollow sandstone" or reputed "Reagan") has also been studied for storage capacity. This sandstone is believed to pinch out eastward against the Cambridge Arch (Rogers, 1977). Based on well penetrations, we surmise that local, gentle basement topography controls the distribution of this thin sandstone in the study area. We have no evidence that this basement topography is directly associated with any geologic structures smaller than the scale of the Cambridge Arch itself. The SHRU 86A well penetrated no faults. The sedimentary succession penetrated by the borehole contained two open fractures, although the weathered ( $22 \mathrm{ft}$ thick) and intact basement-rock ( $\sim 87 \mathrm{ft}$ thick) intervals in the borehole contained 
many open fractures. During a short-term monitoring program in the 1980s, Evans and Steeples (1987) note that 50 microseismic events in Phanerozoic sedimentary cover plus 126 microseismic events in the basement rock were observed around the study area. The relationship of these microseismic events to any geologic structures, or to local water injection EOR have not been established. 


\section{Establishing a Stratigraphic Framework for the Static Earth Model}

We interpret the stratigraphic framework for the LKC in the context of the existing model for Pennsylvanian cyclothems in the Midcontinent, USA. The "Kansas-type" cyclothem (e.g., Heckel, 1986; Heckey and Watney, 2002; Figure 3-4a) proposed in studies of the Pennsylvanian outcrop belt, far to the east of our study area, is bounded below by an "outside" shale (in fact, typically in part, or in its entirety, massive mudstone or claystone) that exhibits evidence for subaerial exposure and soil development. A comparatively thin transgressive limestone exists atop the "outside" shale, and the transgressive limestone is overlain by a deeper-water "core" shale. Atop the "core" shale is a thick regressive limestone, which is overlain by another "outside" shale (Figure 3-4a). Black "core" shales are typified by significant peaks in the GR $\log$ response.

There are challenges in applying the outcrop-based cyclothem model to our study area, far to the west, on a structural high in the subsurface. Chiefly, there is markedly less evidence for the black "core" shales (like in the high GR response in the LKC-C, Figure 3-3) in the study area than in other parts of the midcontinent Pennsylvanian platform. Although some darker shale units are present in particular stratigraphic positions that are comparable to those of "core" shales in the outcrop belt, gamma ray logs (GR > 120) indicate that such instances are not the rule (Figure 3-3). Thus, where such marine shales are missing, transgressive limestone units are directly overlain by regressive limestones (Figure 3-4b), affecting the appearance of a single, very thick limestone package in GR logs (Figure 3-4c). LKC zone "B," which is comprised of two cyclothems, is a notable example (Figure 3-5). The Eudora and Hickory Creek shale members here lack transgressive "core" shales observed in outcrop (Figure 3-5) (except for the high GR interval between LKC C and D). In comparison, the Dopita A-16 well, 82 miles southeast of the present study area, shows more instances of black "core" shales, both in GR logs and core (Young, 2011). We surmise, as has Watney (1980), that local paleogeography and environmental conditions (bathymetry, circulation, availability of sediment and organic matter, etc.) on and around the Cambridge Arch even in the context of eustatic sea-level changes were unsuitable for the deposition of typical "core" shale facies. 
Accordingly, we present a revised sea-level curve (Figure 3-4b) for the study area. Furthermore, because this Upper Pennsylvanian epicontinental sea is very flat, there will be no evidence of turbidites or basin floor fans. Sedimentary thickening will be through aggradation. Although not present along the Cambridge Arch, closer to the sea's boundary, there is evidence of erosion in the form of channel and valley fill. (Fielding and Joeckel et al., 2018).

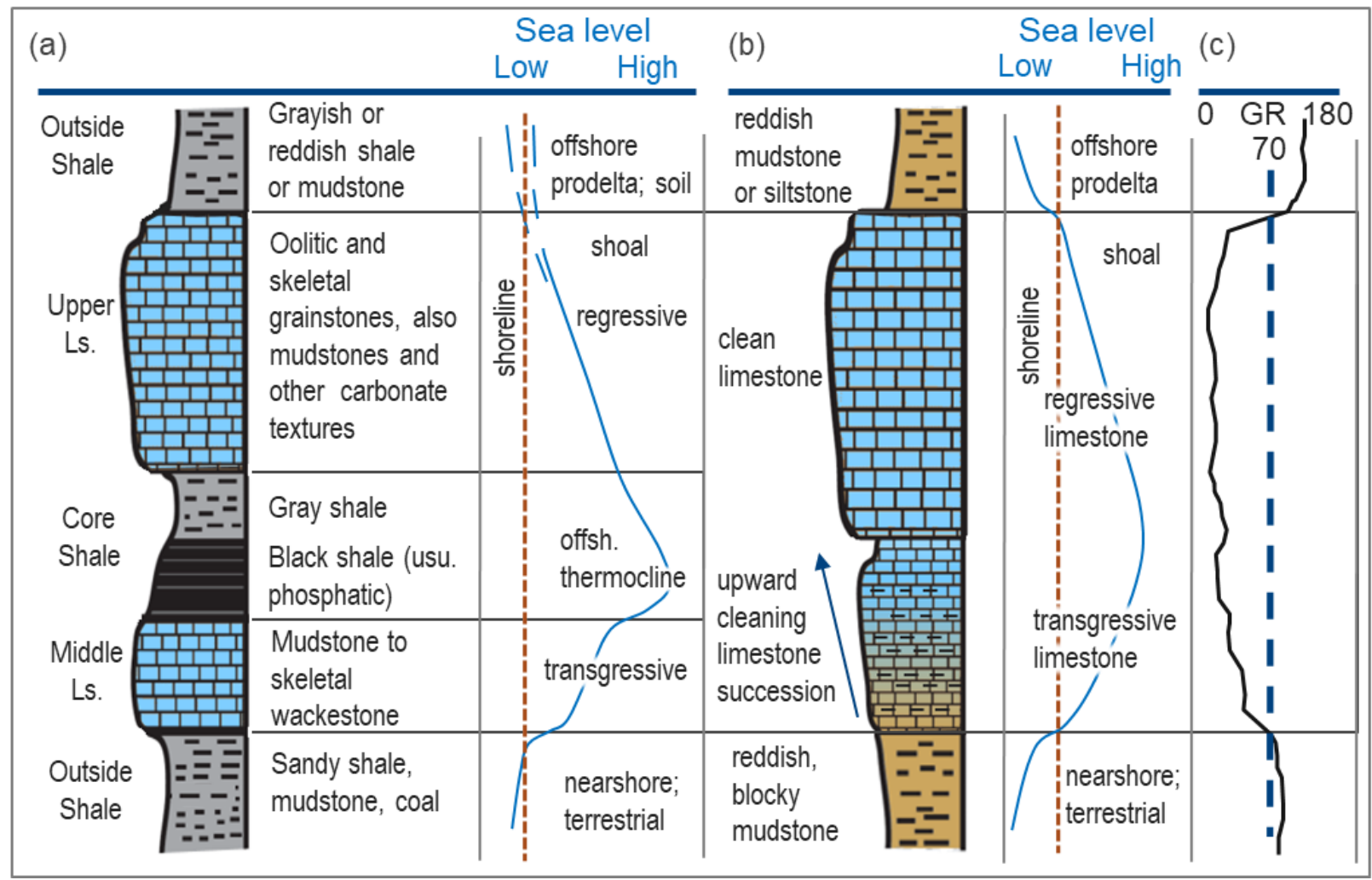

Figure 3-4. Pennsylvanian carbonate cycle. (a) Example of Kansas-type cyclothem, modified after Heckel (1986). (b) Adaptation of the carbonate cycle more commonly seen at Sleepy Hollow Field, NE. (c) Representative GR log response usually seen for carbonate units like that shown in (b). 


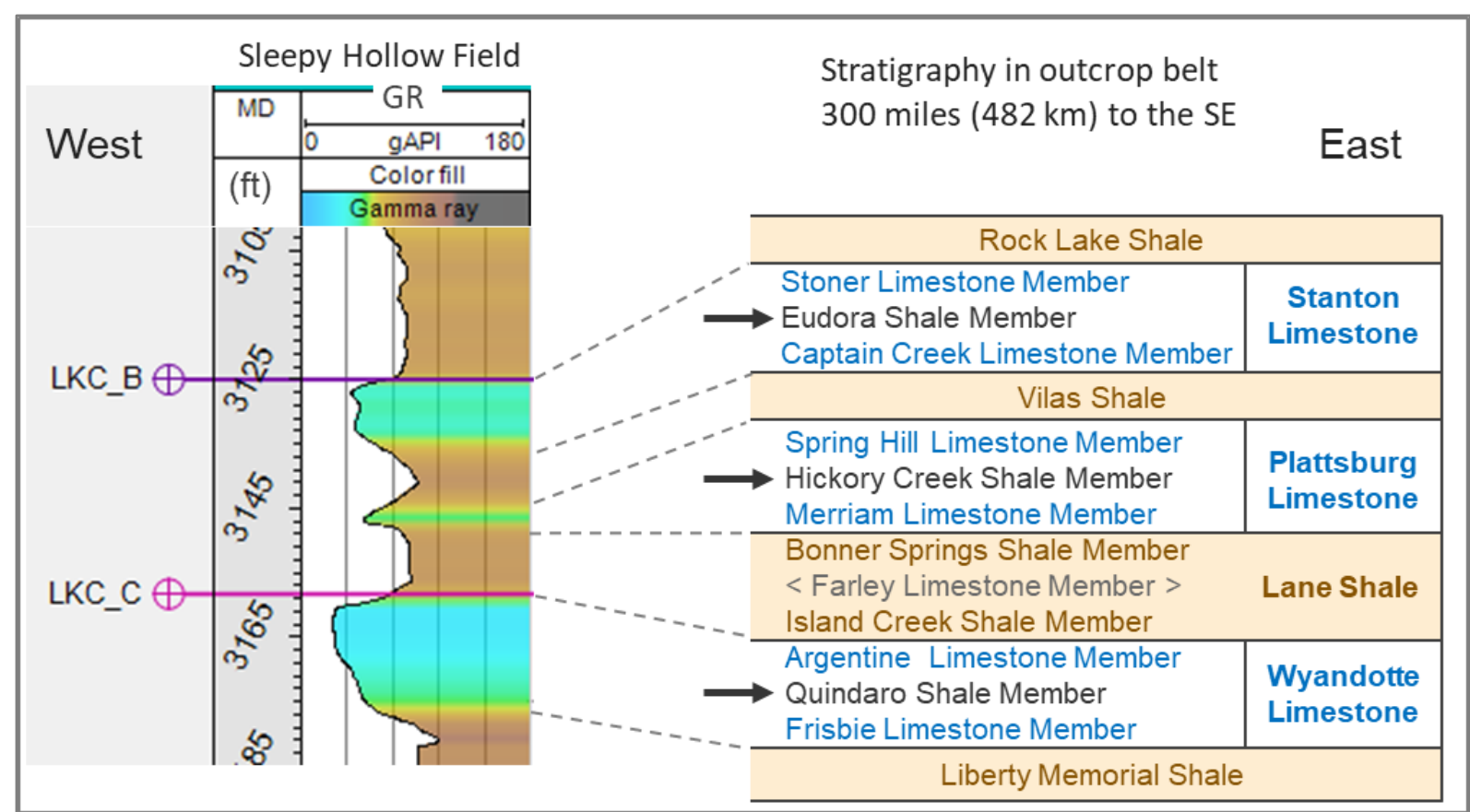

Figure 3-5. Interpretation of Pennsylvanian carbonate cycles at Sleepy Hollow Field and their correlative geologic member names as formally named in outcrops, using the revised stratigraphic scheme of Heckel and Watney (2002). The intervening transgressive shale units (marked by arrows) are either absent or too thin to be resolved by GR logging. The thicker regressive shale units tend to be mudstones and have pedogenic features.

\section{Interpretation of Cores and Thin Sections}

Detailed descriptions of a few pre-existing cores in the study area and a small but representative set of thin sections produced from those cores were the basis for characterization of critical lithologies (carbonate rocks and mudrocks) in the LKC.

Example sidewall core samples from the LKC are described in Table 3-1 and are plotted, in depth, against gamma ray log response for the SHRU 86A well (Figure 3-6). These sidewall cores correlate with the gamma ray logs, with low gamma ray response corresponding to carbonate rock and higher gamma ray reflecting clay-rich mudrocks. While discrimination of carbonate textures cannot be determined based on wireline logs, the GR log is sufficient as a standalone input for the development of a coarse facies model. Several outcrop and core-based studies of the LKC across Kansas and in Nebraska have demonstrated that mudstones and wackestones are common limestone textures in the LKC, but also that grainier limestone facies appear at particular stratigraphic levels (Heckel, 1986; Heckel, 1994; Heckel, 2008). Oolitic, 
skeletal, and peloidal grainstones in the $\mathrm{LKC}$ were targeted for the assessment of $\mathrm{CO}_{2}$ storage in the Sleepy Hollow field and sampled for petrography and mineralogy. In the Harsch \#6 well, oolitic grainstones exhibit dominantly moldic and vugular porosity, and minor intergranular porosity (Figure 3-6f, "H1" in Figure 3-1b). Individual ooids are uniformly recrystallized to calcite microspar. Peloidal and skeletal grainstones were also encountered (Figure 3-6g). The peloids in such rocks are mictitic overall but also partially neomorphosed, and they have indistinct or very indistinct outlines. Peloid-dominated domains exhibit both inter- and intragranular porosity. Skeletal allochems in grainstone domains include fusulinids and ostracodes, fragments of brachiopods and bryozoans, and undetermined fossil fragments. In some thin sections, most of the skeletal grains have micritized envelopes (Figure 3-6e). Some larger skeletal allochems (e.g., brachiopod fragments) have also been replaced by coarse, blocky calcite spar. Rare open voids that appear to be molds of large skeletal allochems may indeed represent very minor moldic porosity, or they may be the results of the plucking of void filling spar during thin section preparation. Only one limestone sample proved to be partially dolomitized, but because so few thin sections were produced, the overall incidence of dolomitization cannot be determined.

Mudrocks are the only truly widespread clastic rocks in the LKC overall. During core description, intervals exhibiting lamination and fissility were identified as clay and silty clay shales; in thin section, these characteristics were supported by the identification of 0.5-3.0 mm laminae (Figure 3-6h). Likewise, during the description of the core, intervals lacking well-organized depositional sedimentary structures were characterized as claystone; in thin section they often exhibited small granular to blocky aggregates that probably represent preserved soil structure (Figure 3-6i). Birefringence fabrics in our comparatively few thin sections of mudrocks are mostly masked by abundant iron oxides that impregnate rock matrices, making it very difficult to differentiate patterns of optical anisotropy that might be of primary depositional origins to those that may have been produced by subsequent pedogenesis. Representative thin sections and their descriptions are summarized in Table 3-2 and shown against a gamma ray log (Figure 3-6). 
Many of the mudstones that we examined closely in our study are at least partially reddened because either: (1) the precursor sediments were already oxidized when they were deposited, or (2) the oxidation of these sediments occurred after deposition and in association with an overlying subaerial exposure surface. Several paleosols have been documented in mudstones within the LKC and other Upper Pennsylvanian cyclothems both in the outcrop belt and in the deep subsurface far to the west (Joeckel, 1989, 1994, 1999; Prather, 1985).

Table 3-1. Example sidewall core samples from SHRU 86A. The ID corresponds to samples shown with gamma ray well log in Figure 3-6.

\begin{tabular}{ll}
\hline ID & Description \\
\hline (a) & Limestone. White, w/ stylolite, appears tight, some dolomite near stylolite. \\
(b) & Mudrock. Dark grayish-green, laminated, more shaley. \\
(c) & Limestone. Oil stained in parts, pinpoint vugs, poss. moldic porosity, greyish-white. \\
(d) & Mudrock. Reddish, muddy, clay, unconsolidated. \\
\hline
\end{tabular}

Table 3-2. Example LKC thin section descriptions. The ID corresponds to samples shown with gamma ray well log in Figure 3-6.

\begin{tabular}{|c|c|c|c|}
\hline ID & Lithology & Description & $\begin{array}{l}\text { Porosity and } \\
\text { Permeability }\end{array}$ \\
\hline (e) & Grainstone & $\begin{array}{l}\text { Partially micritized skeletal grains with micrite envelopes, fusulinids, } \\
\text { fragments of coralline red algae. Dominantly intergranular porosity and } \\
\text { subordinate intragranular porosity }\end{array}$ & $\begin{array}{l}\text { Phi=6.94\% } \\
\mathrm{K}=0.017 \mathrm{mD}\end{array}$ \\
\hline (f) & $\begin{array}{l}\text { Oolitic } \\
\text { grainstone }\end{array}$ & $\begin{array}{l}\text { Ooids have been recrystallized to microspar. Dominantly moldic and } \\
\text { vugular porosity; very minor intergranular porosity, }\end{array}$ & $\begin{array}{l}\mathrm{Phi}=17.86 \% \\
\mathrm{~K}=33.962 \mathrm{mD}\end{array}$ \\
\hline (g) & $\begin{array}{l}\text { Peloidal/ } \\
\text { skeletal } \\
\text { grainstone }\end{array}$ & $\begin{array}{l}\text { Recrystallized and partially dolomitized. Largely recrystallized calcitic } \\
\text { allochems (echinoderms, brachiopods, ostracodes, and indeterminate), } \\
\text { many of which have micrite envelopes. Peloids with indistinct to very } \\
\text { indistinct outlines, partially to mostly dolomitized microspar and finely } \\
\text { crystalline dolomite }\end{array}$ & $\begin{array}{l}\mathrm{Phi}=14.11 \% \\
\mathrm{~K}=3.942 \mathrm{mD}\end{array}$ \\
\hline (h) & Clay shale & $\begin{array}{l}\text { Silt at } 10 \mathrm{x} \text { magnification. Laminae } 0.4-1.2 \mathrm{~mm} \text { thick, indeterminate (few } \\
\text { calcitic, invertebrate skeletal grains). Few opaque iron oxide mottles } \\
\text { roughly parallel to lamination. XRF result for hematite: } 3.29 \%\end{array}$ & $\begin{array}{l}\text { Phi }=12.30 \% \\
\mathrm{~K}=0.001 \mathrm{mD}\end{array}$ \\
\hline (i) & Claystone & $\begin{array}{l}\text { Silt at 10x magnification. Massive; possible soil structure (very fine-fine, } \\
\text { granular), silt-filled crack infillings or burrows } 0.2-1.0 \mathrm{~mm} \text { in width, with } \\
\text { weak speckled birefringence fabric; partial masking of birefringence by } \\
\text { iron oxides; drab mottling. Porosity appears to be entirely the result of } \\
\text { fracturing after collection/preparation and plucking. XRF result for } \\
\text { hematite: } 5.28 \%\end{array}$ & $\begin{array}{l}\text { Phi=18.05\% } \\
\mathrm{K}=0.001 \mathrm{mD}\end{array}$ \\
\hline
\end{tabular}




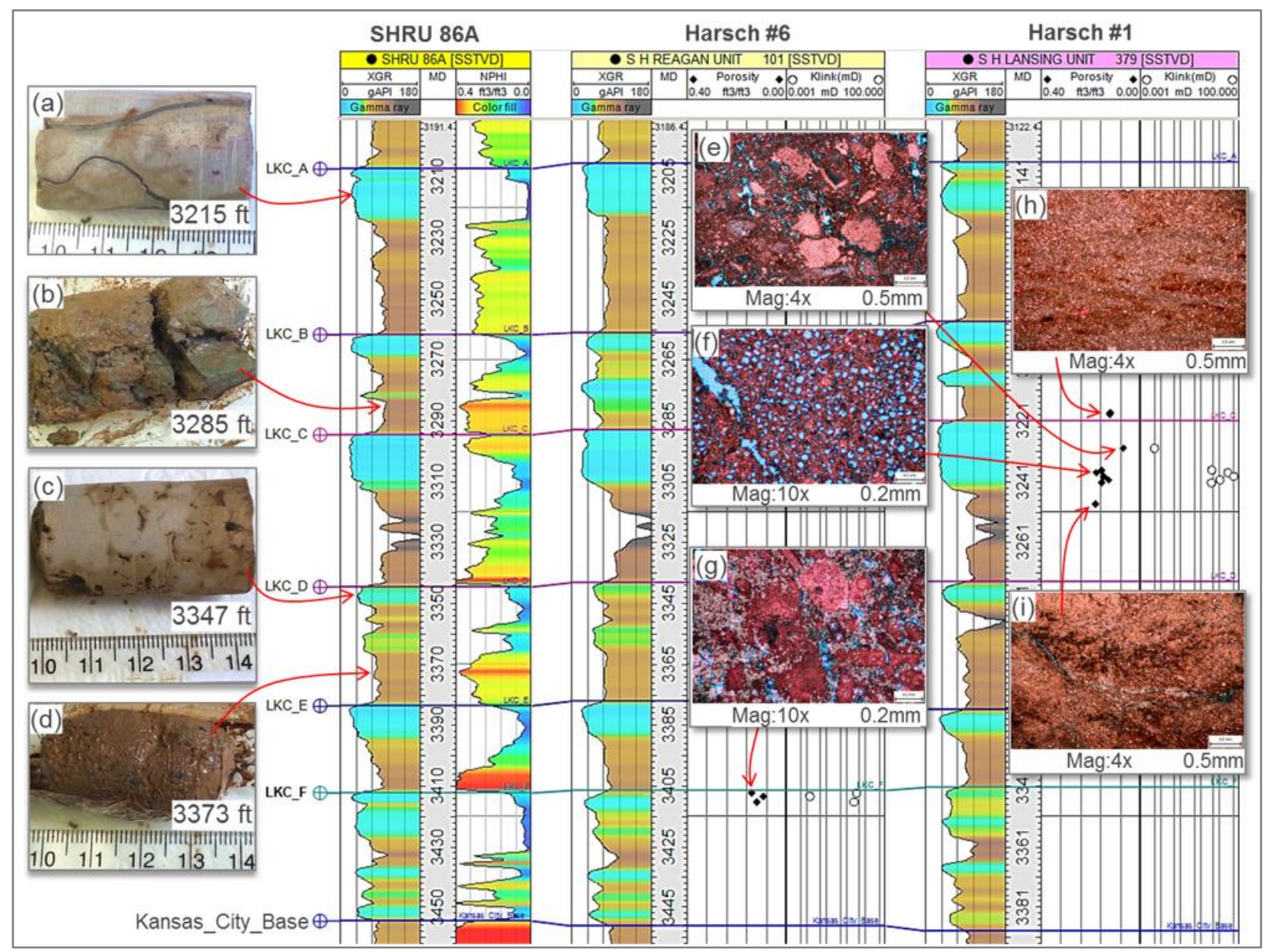

Figure 3-6. Representative sidewall core samples and thin sections with gamma ray logs. Samples (a) through (i) are described in Tables 1 and 2. Well locations are provided in Figure $1 b$. 


\section{Interpretation of Log Data}

We characterize the Sleepy Hollow Field (SHF) using vintage (mostly pre-1970) well logs from 205 wells located predominately within the field and several from outside the field. These well $\operatorname{logs}$ typically include gamma ray, neutron porosity, spontaneous potential, and resistivity. Core interpretations and thin sections are based on five wells in and around SHF and include LKC zones "B," "C," and "F" (Figures 3-1b and 3-6).

Data obtained from the new SHRU 86A stratigraphic test well included the logs mentioned above plus a full suite of advanced logs, including a borehole image log (FMI), nuclear magnetic resonance (NMR) logging, and elemental capture spectroscopy (ECS) logging. These new logs have provided further validation of our preliminary classification of limestones and mudrocks.

The static FMI log shows very sharp upper contacts for the regressive limestones that are overlain by mudrocks and can be used to refine our LKC zonal picks (Figure 3-7). Darker areas in the image are due to conductive intervals attributed to clay-bound water in the mudrocks. Although conductive and porous, laboratory-measured results in Table 3-2 show that the mudrocks are indeed tight with a permeability of $0.001 \mathrm{mD}$. In contrast, the light areas on the FMI log correspond to the resistive carbonate units suggesting lower, but effective porosity. The porosity of the carbonate rocks varies significantly, but more importantly, these rocks do have some permeability, albeit less than $50 \mathrm{mD}$ (Tables 3-2 and 3-3).

NMR logging uses pulsed magnetic fields to affect the orientation and alignment of hydrogen atoms that are found in water and oil. Measurement of the decay time (T2) provides a quantitative assessment of pore size, with tiny pores associated with clay-bound water and larger pores associated with porosity development within carbonate rock and sandstone where a fluid is free to move (Appel, 2004). The goal of the NMR logging in SHRU 86A was to accurately identify clay-bound water so that it could be eliminated from total porosity, thereby producing more reliable estimates of effective porosity. Unfortunately, the NMR log response proved very sensitive to the thick mud cake that accumulated on the particularly rugose mudrock sections of the borehole wall. Therefore, the NMR logging tool could not sense deeply and predict 
free fluid volumes (effective porosities) in limestone reservoirs. On the other hand, the ECS tool (Elemental capture spectroscopy sonde) (Schlumberger, 2020) penetrated deeper, and its results are considered reliable, especially in the context of GR and NPHI logs and the examination of core samples.

The new ECS logging in the SHRU 86A well compliments the GR facies model and validates the dominance of calcite in our limestones (our carbonate-dominant GR facies), and the dominance of clay minerals and quartz in shales and mudstones (Figure 3-7). This information, coupled with observations we have made from core and thin sections, provides a better-integrated picture for LKC intervals where core is absent. 


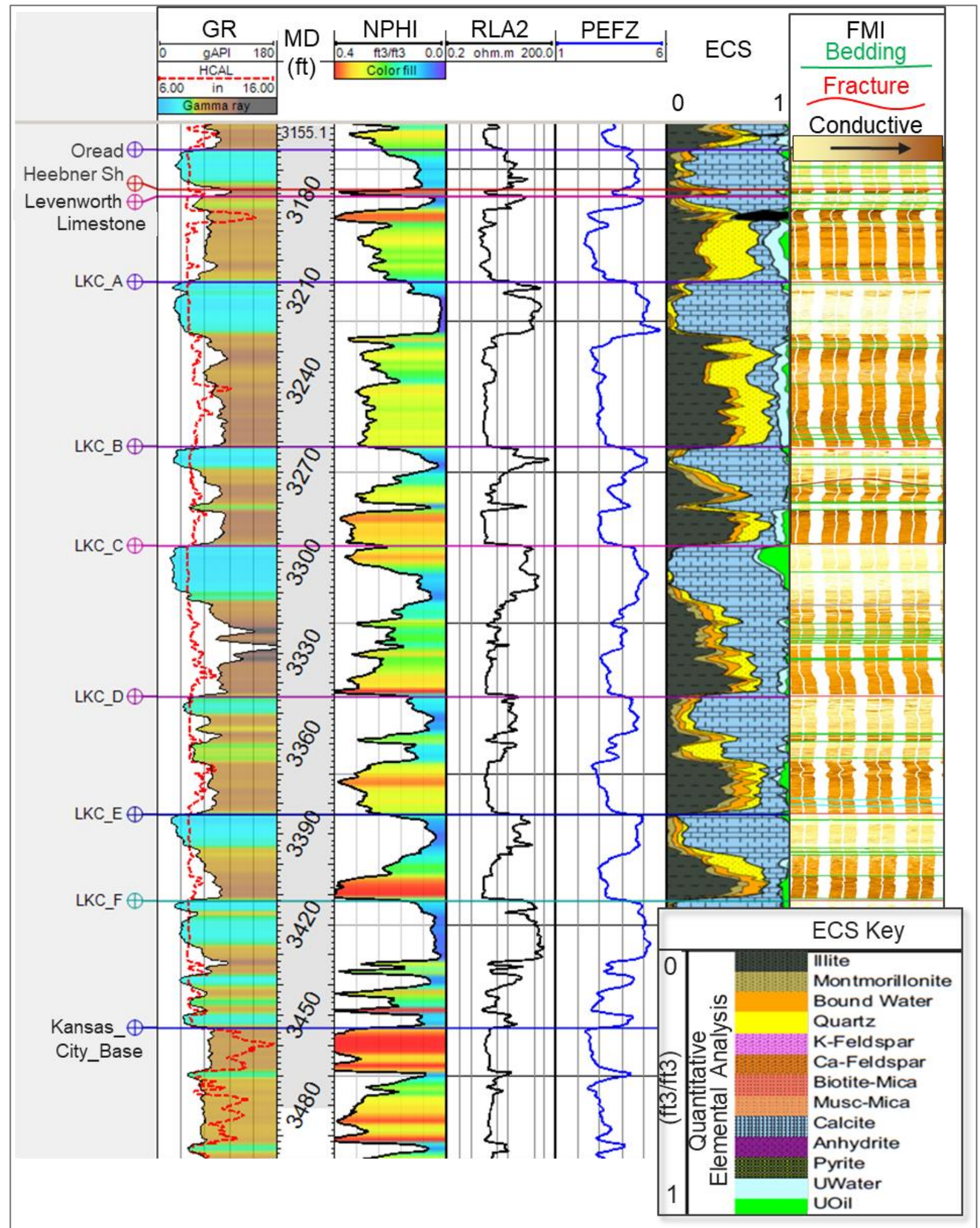

Figure 3-7. Logs from stratigraphic test well SHRU 86A showing LKC zones "A" through "F." Tracks from left to right: GR (Gamma ray), HCAL (Caliper), NPHI (Neutron Porosity), RLA2 (Resistivity), PEFZ (Photoelectric Factor), ECS (Elemental Capture Spectroscopy), FMI (Fullbore Formation Microimager). ECS key: K (Potassium), Ca (Calcium), Musc (Muscovite), Uwater (movable water), and UOil (movable Oil). 


\section{Static Earth Model Development}

The carbon storage assessment for Sleepy Hollow Field required the development of a static earth model representing the petrophysical properties of the reservoir units and caprocks. Hydrologically, the LKC is an open system in which the storage area and thickness are relatively well-defined by well control. The modeling workflow steps are described below and concludes with $\mathrm{CO}_{2}$ storage estimate calculations. The geomodeling workflow is summarized in Figure 3-8.

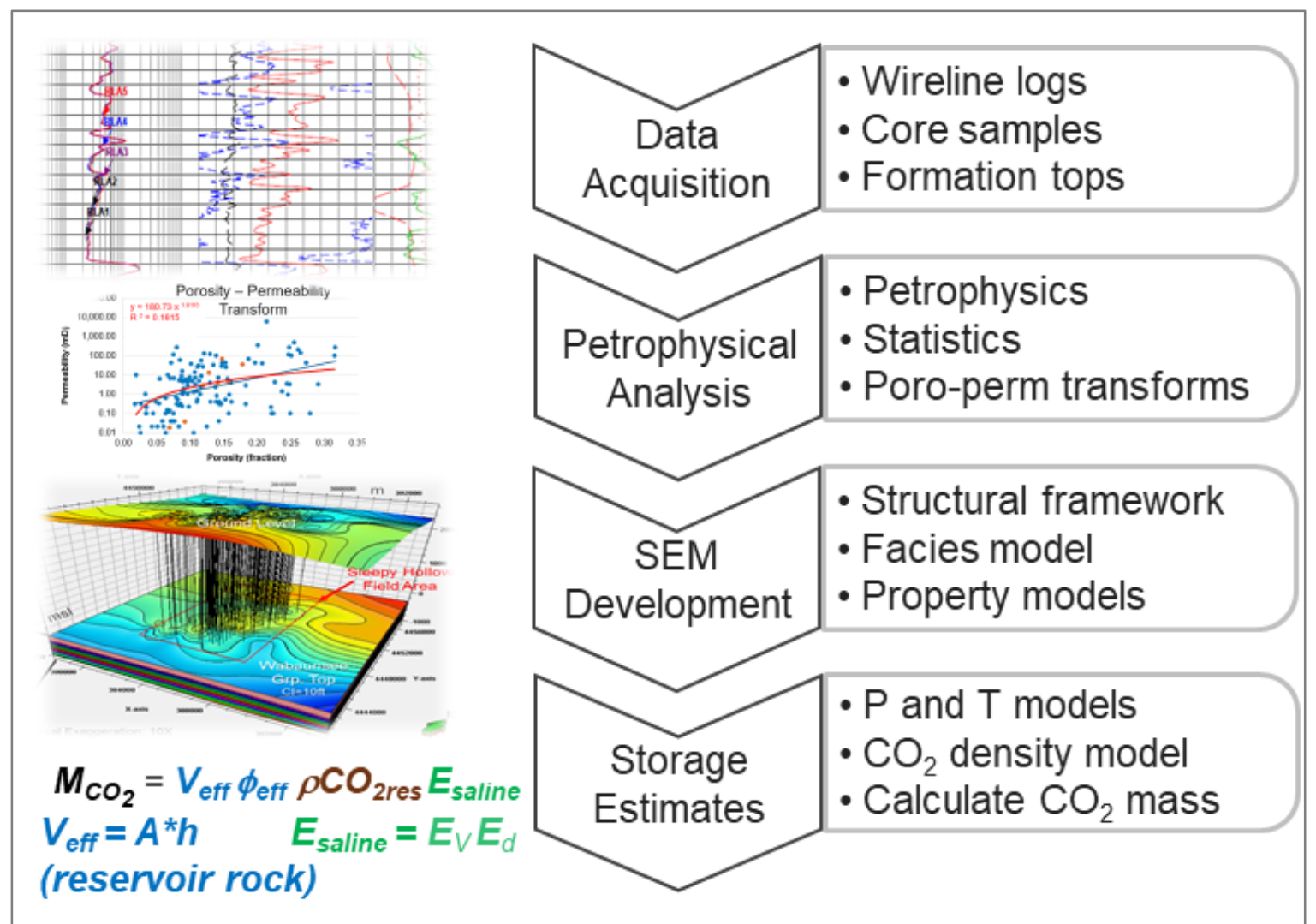

Figure 3-8. Workflow for the construction of geocellular models to calculate the effective storage resource potential for $\mathrm{CO}_{2}$.

\section{1) Data Acquisition}

Well logs from 205 wells in and around Sleepy Hollow Field were collected and digitized (Battelle, 2018). Well top picks and well header data were compiled. Existing core samples in the study area were identified and submitted for core analysis. A new well, SHRU 86A, was drilled, cored, and logged in June 2019. 


\section{2) Data Quality Control (QC)}

Well log data went through an extensive QC process, which included the validation of wellhead elevations and formation-top picks. Gamma ray logs were normalized to ensure that the range of their response was similar among the 200+ wells. Neutron porosity (NPHI) logs were sensitive to the clay-bound water porosity, and so it was necessary to prepare effective porosity logs. The $\mathrm{V}_{\text {shale }}$ correction method (Asquith, 2006) was used per equations 3-1 and 3-2.

$\mathrm{V}_{\text {shale }}=\left(\mathrm{GRlog}-\mathrm{GR}_{\mathrm{res}}\right) /\left(\mathrm{GR}_{\text {shale }}-\mathrm{GR}_{\text {res }}\right) \quad[\mathrm{Eq}$. 3-1]

Where:

$\mathrm{V}_{\text {shale }}=$ shale fraction (i.e. non-reservoir)

$\mathrm{GR}_{\log }=$ gamma ray log value

$\mathrm{GR}_{\text {res }}=$ gamma ray value of clean (i.e., low clay) carbonate rock in each zone

$\mathrm{GR}_{\text {shale }}=$ gamma ray value from a nearby shale interval

PHIe $=$ PHI $_{t} \times\left(1-\mathrm{V}_{\text {shale }}\right) \quad$ [Eq. 3-2]

Where:

$\mathrm{PHI}_{\mathrm{e}}=$ effective porosity

$\mathrm{PHI}_{\mathrm{t}}=$ total porosity (uncorrected, typically NPHI)

$1-\mathrm{V}_{\text {shale }}=$ sandstone and/or carbonate fraction (i.e. reservoir fraction)

\section{3) Data Import}

Log data and available well tops were imported into a subsurface interpretation and modeling software that enabled the development of a 3D geocellular, petrophysical model. The modeling package permits the computation of pore volume and the subsequent reporting of pore volume results by facies and by model zone.

\section{4) Generate Surfaces and SEM Framework}

Zonal tops for the LKC limestone intervals were picked on the tops of low GR signatures (Figures 3-3 and 3-9a). These picks are consistent with the tops of regressive carbonates, which typically include the best reservoir-quality rock. This step provided an opportunity to pick missing formation tops and validate existing ones through well correlations in cross-section views. The high density of wells, top picks, and their correlation provided the key input for creating surfaces. 


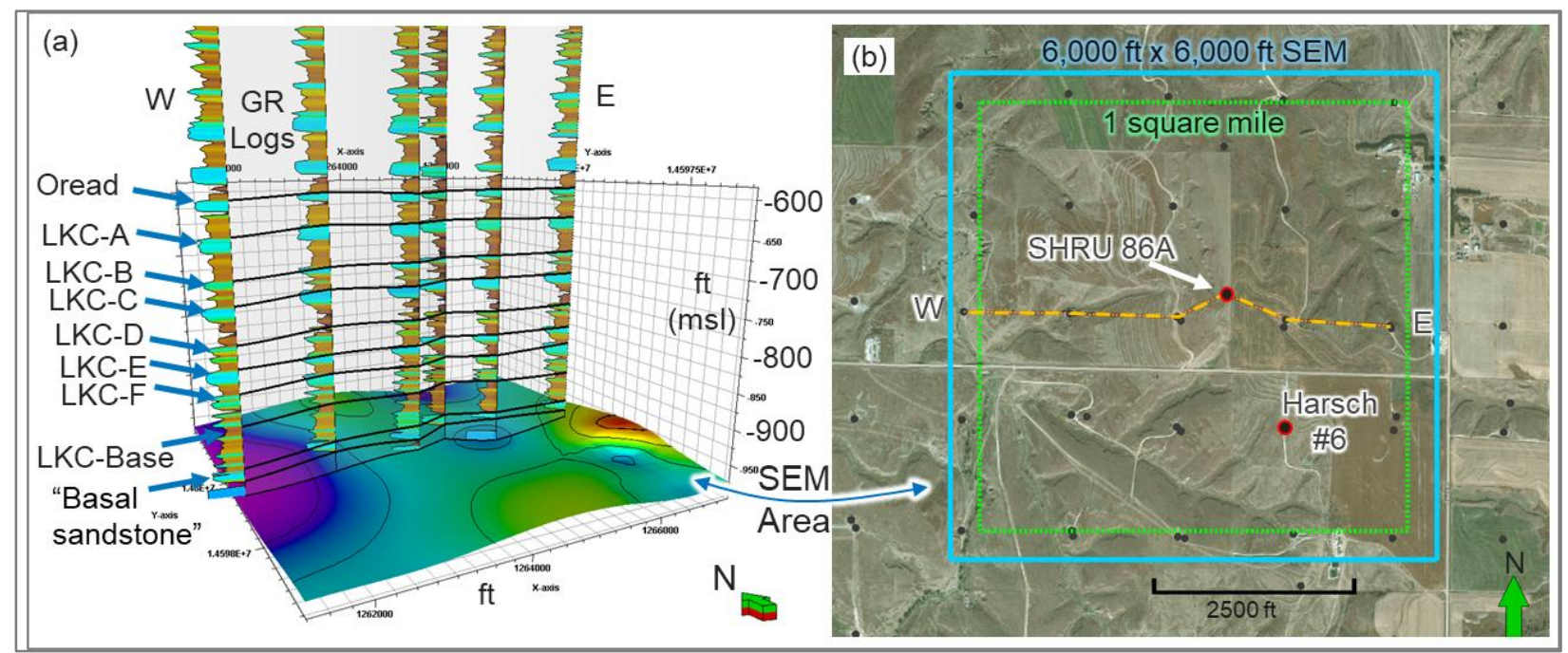

Figure 3-9. Well section across SEM. a) Well section showing LKC carbonate rock top picks based on GR logs. b) Map view of SEM area and location of well section at left. Also shown are well locations (black dots) and area in which $\mathrm{LKC} \mathrm{CO}_{2}$ storage estimates were calculated (stippled, square mile).

Surfaces for many carbonate tops were created with the top picks using Schlumberger's Petrel ${ }^{\circledR}$ 2016 convergent interpolation algorithm. According to the software description: "this is a control-point orientated algorithm rather than grid-point oriented one. It converges upon the solution iteratively, adding more resolution with each iteration. General trends are retained in areas with little data, while detail is honored in areas where the data exists". Surfaces for the LKC section down to basement were made across the SHF. The SEM framework presented here was constrained to 26 wells and represents a smaller portion of the full field-scale SEM (Figure 3-10a). The intervals between carbonate top surfaces define the zones in the 3D geocellular grid of the SEM (Figure 3-10b). Each zone was easy to correlate among wells across the field. A dominant limestone unit typically represented the upper portion of each zone; some zones had two or more thinner limestones. The SEM grid is comprised of cells with projected $50 \mathrm{ft}$ x $50 \mathrm{ft}(15.4 \mathrm{~m} \mathrm{x}$ $15.4 \mathrm{~m})$ extents in the $\mathrm{x}$ and $\mathrm{y}$ directions. Each zone was then layered in 2-foot $(0.61 \mathrm{~m})$ increments resulting in a 243-layer SEM with 120 cells in the x-direction, 120 cells in the y-direction. Thus, the SEM has $3,499,200$ total cells $(120 \mathrm{i} \times 120 \mathrm{j} \times 243 \mathrm{k})$, a footprint of $6,000 \times 6,000$ feet $(1,828.7 \times 1,828.7 \mathrm{~m})$, and a total thickness of $384 \mathrm{ft}$ (117.0 m) (Figure 3-9b, and Figure 3-10b). 


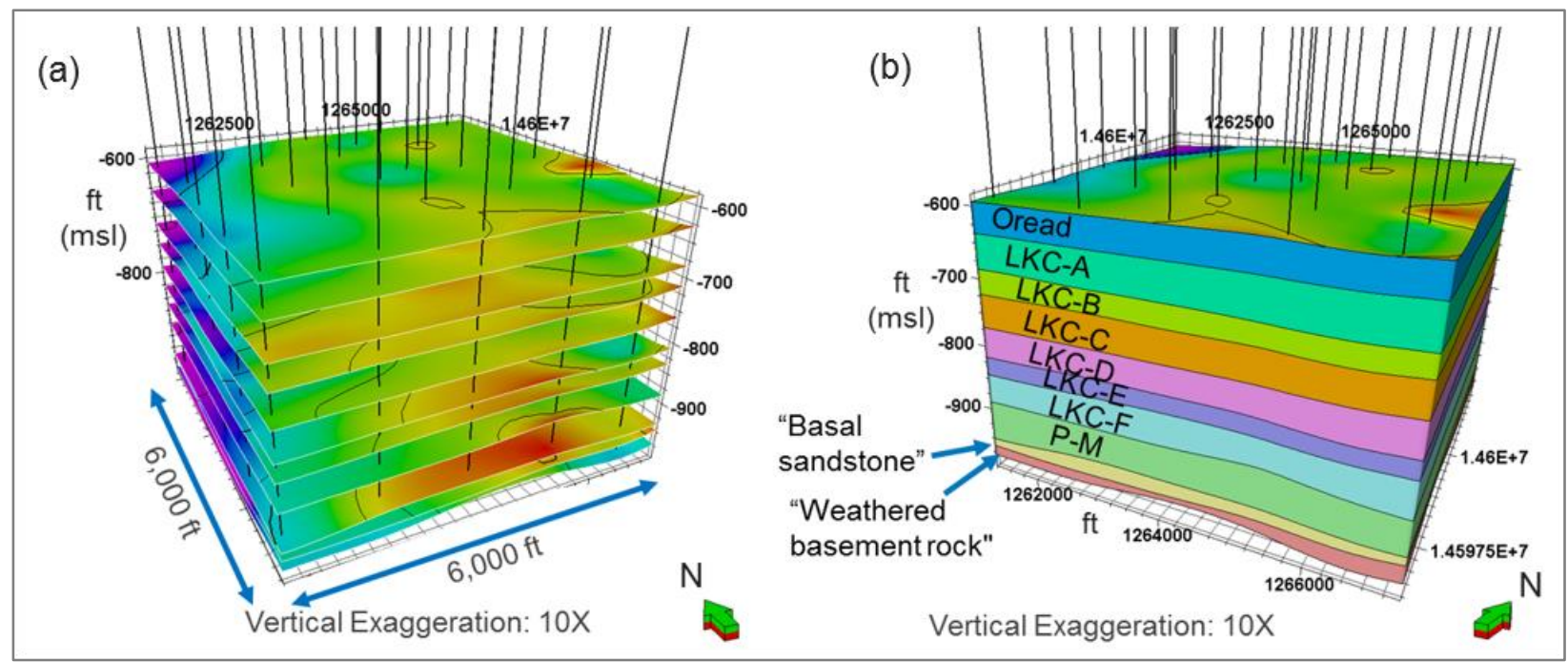

Figure 3-10. SEM surfaces and framework. a) Surfaces representing the tops of key carbonate rock units; vertical black lines are wells. b) SEM with zones defined by surfaces. $P$-M is the undifferentiated Pleasanton and Marmaton groups. SEM framework is 6,000 ft $\times 6,000 \mathrm{ft} \times 384$ feet thick $(1,828 \mathrm{~m} \times 1,829$ $x 117 \mathrm{~m}$ ); this is from top of Oread down to top of Precambrian basement.

\section{5) Facies Model}

Facies models enable better control for delineating where and how petrophysical properties are distributed within each SEM zone. Within the LKC, individual lithostratigraphic units are laterally extensive, and the highest variability in rock characteristics is in the vertical direction. GR log signatures provided the basis for dividing the zones into three lithofacies or flow units.

Stratigraphic intervals exhibiting low gamma ray values $(<70$ gAPI $)$ were attributed to clean limestones. These limestones may be mostly wackestones and mudstones, but oolitic limestone, skeletal, and peloidal grainstones are also present, and these textures have the best porosity. Units identified as limestones had better reservoir properties overall than the units that were identified as mudrocks. Other studies (Watney, 1980; Young, 2011) have demonstrated that the clean, regressive limestones, especially those that were subjected to subaerial exposure before deep burial, have better porosity development. Stratigraphic intervals exhibiting higher gamma ray values (> 70 gAPI) generally represent mudrocks. Mudrocks are considered to be low-permeability baffles that inhibit the vertical migration of $\mathrm{CO}_{2}$. Thus, such units were considered as tight for modeling purposes. Interpreted deeper-water, transgressive, 
offshore-marine shales (the black "core" shales of Heckel, 1986, 1994, 2008) characterized by very high gamma-ray responses (> 120 gAPI) were not observed in all cyclothems at Sleepy Hollow Field. These shales are assumed to be tight in our facies determination, and they are combined with what we interpret to be regressive mudstones. We developed a simplified model consisting of three GR facies corresponding to general ranges of rock characteristics associated with gamma ray responses (Table 3-3; Figure 3-11).

Table 3-3. Gamma ray facies and codes used in this study for Pennsylvanian cyclothems.

\begin{tabular}{|c|c|c|c|}
\hline $\begin{array}{c}\text { Gamma Ray } \\
\text { Facies Code and } \\
\text { (Gamma Ray log) }\end{array}$ & Lithology & Depositional Setting & Porosity and Permeability \\
\hline \multirow[t]{2}{*}{$\begin{array}{c}0 \\
(0-70 \text { gAPI) }\end{array}$} & $\begin{array}{l}\text { Carbonate-dominated; } \\
\text { oolitic, peloidal, and } \\
\text { skeletal grainstones are of } \\
\text { special interest as reservoir } \\
\text { rocks. It also includes other } \\
\text { carbonate rock types } \\
\text { including mudstones and } \\
\text { wackestones. }\end{array}$ & $\begin{array}{l}\text { Transgressive or } \\
\text { regressive offshore } \\
\text { marine. Porosity may } \\
\text { be enhanced through } \\
\text { subaerial exposure and } \\
\text { infiltration by meteoric } \\
\text { water. }\end{array}$ & $\begin{array}{l}\text { Good porosity development. } \\
\text { Regressive packages tend to } \\
\text { be thicker than } \\
\text { transgressive ones. In the } \\
\text { absence of an intervening } \\
\text { unit of gamma ray facies } 2 \text {, } \\
\text { successive regressive and } \\
\text { transgressive packages may } \\
\text { appear as a single, thick } \\
\text { carbonate succession. }\end{array}$ \\
\hline & & & $0.1 \mathrm{mD}<\mathrm{K}<50 \mathrm{mD}$ \\
\hline $\begin{array}{c}1 \\
(70-120 \text { gAPI) }\end{array}$ & $\begin{array}{l}\text { Mudstone-dominated, } \\
\text { includes reddish siliciclastic } \\
\text { mudstones, with } \\
\text { pedogenetic features. }\end{array}$ & $\begin{array}{l}\text { Regressive, nearshore- } \\
\text { marine depositional } \\
\text { environment subjected } \\
\text { to subaerial exposure, } \\
\text { oxidation, and soil } \\
\text { development during } \\
\text { and after regression. }\end{array}$ & $\begin{array}{l}\text { Considered tight. It has high } \\
\text { total porosity due to water- } \\
\text { bound clay. Effective } \\
\text { porosity likely poor. Core } \\
\text { reports often show } \\
\text { permeability as } 0.001 \mathrm{mD} \text {. }\end{array}$ \\
\hline $\begin{array}{c}2 \\
(120+\text { gAPI })\end{array}$ & $\begin{array}{l}\text { Black or dark gray shale. At } \\
\text { SHF, usually absent. }\end{array}$ & Transgressive marine. & $\begin{array}{l}\text { Tight. For modeling } \\
\text { purposes, this shale was } \\
\text { grouped with facies code } 1 .\end{array}$ \\
\hline
\end{tabular}




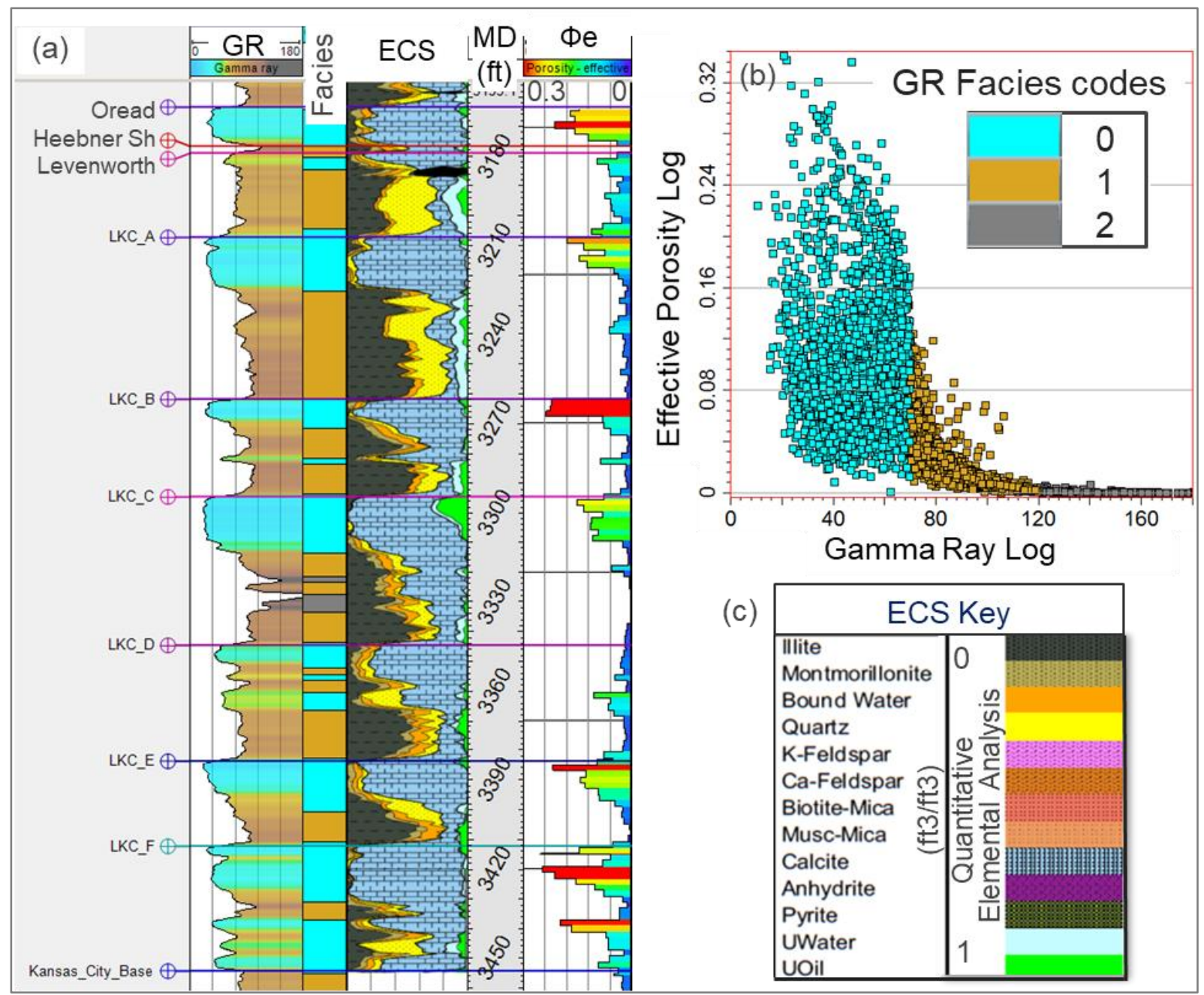

Figure 3-11. LKC facies delineation based on gamma ray log thresholds. (a) Gamma ray log, facies color codes, ECS, and effective porosity for the LKC. (b) Effective porosity versus Gamma ray showing porosity partitioned by facies. c) ECS key.

Our facies model was prepared in two steps: 1) using the arithmetic mean method, the gamma ray logs occurring at half-foot intervals were sampled along their well trajectories into the SEM's two-footthick cells. 2) These data were then interpolated laterally into 3D grid using the moving average method with a point weighting of inverse distance squared. This deterministic approach can quickly populate the 3D grid and can only generate values no smaller or larger than the minimum and maximum values of the input data, respectively. The moving average interpolation technique finds an average of the upscaled log data and weighs according to the distance from the wells. The horizontal setting was isotropic (no preferred azimuthal trends), and vertical range was set to 2 feet (0.61) (Figure 3-12). The moving average method 
was selected because the correlation of GR logs showed that GR facies could usually be traced across the entire oilfield (Figure 3-12a). This facies model is continuous, and a discrete version of it is derived through the gamma ray thresholds as described above and summarized in Table 3-3.

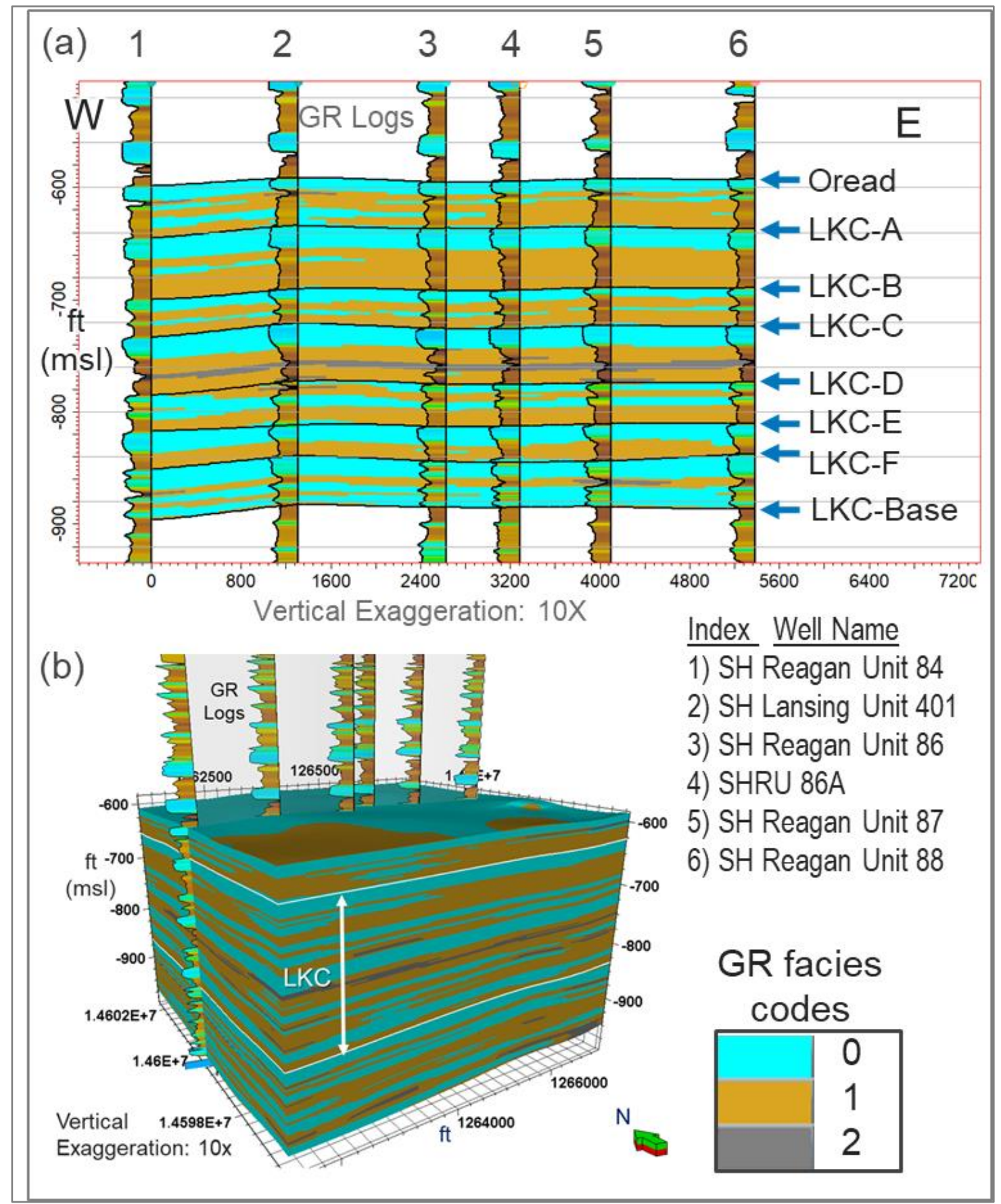

Figure 3-12. GR facies model based on GR log response described in Table 3. (a) Cross section through GR facies model. (b) Oblique 3D view of GR facies model. 


\section{6) Porosity Model}

Effective porosity logs were derived from neutron porosity logs, and they were corrected using the Vshale approach as explained above. A salient problem with this approach is that the selection of an appropriate maximum gamma ray value can be difficult, especially when certain transgressive marine shales ("core" shales of Heckel, 1986, 1994, 2008) produce large GR values. The resulting effective porosity logs for mudrock intervals were considered too large, with many values above 10\% (Figure 313a). In fact, effective porosity for some mudrock intervals, even with the standard Vsh correction, was greater than that for the clean carbonates (the target reservoir). To address this problem, effective porosity logs were attenuated (with an attenuation multiplier of $\left.((150-\mathrm{GR}) / 150)^{\wedge} 2\right)$ such that the effective porosity of the mudrock intervals would be equal to or less than the effective porosities of regressive limestones (Figure 3-13b) and is described further in Chapter 4. For clean (i.e., relatively clay-free) limestones as validated with ECS response (Figure 3-11a), neutron porosity was considered to be a reliable estimate of effective porosity; therefore, raw neutron porosity log values for these strata were used without any adjustments.

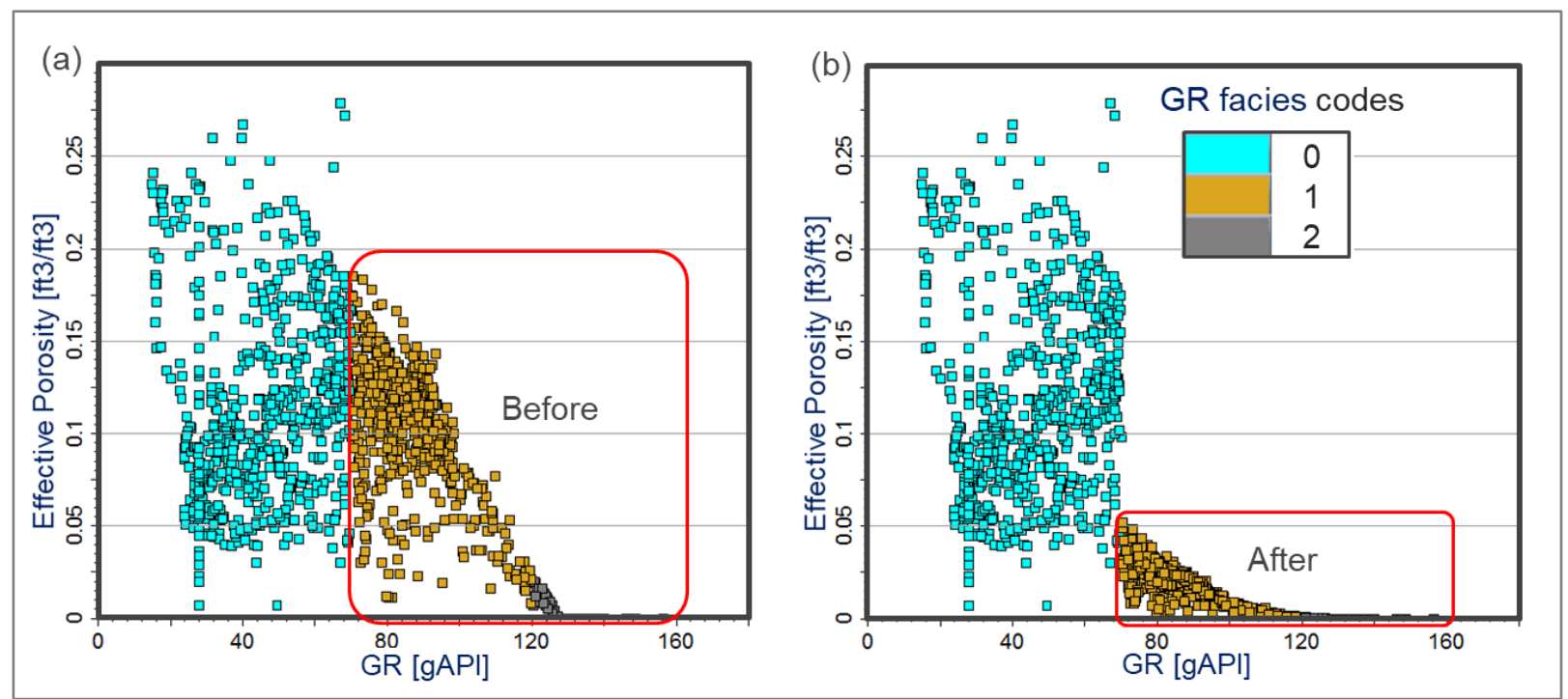

Figure 3-13. Effective porosity logs for carbonate, mudstone, and shale lithologies. (a) Effective porosity partitioned by facies after $V$-shale correction. (b) Same data set with further attenuation to effective porosity logs representing mudstones and shales; thus, red boxes encompass the same population of data points. For an explanation of GR facies codes $(0,1,2)$ see Table 3-3. 
Following the adjustments to the effective porosity logs, the 3D effective porosity model was prepared in a three-step process: 1) The effective porosity logs at half-foot intervals were upscaled (sampled) into the model's two-foot layer grid along the well trajectories using an arithmetic mean method. Basically, porosity is an additive property, and so the mean porosity values were computed over two-foot intervals using mean $=\left(\mathrm{n}_{1}+\mathrm{n}_{2}+\mathrm{n}_{3}+\mathrm{n}_{4}\right) / 4$. 2) An experimental variogram was fit to the sampled effective porosity logs and was provided as geostatistical input to the Gaussian Random Function Simulation (GRFS) method. 3) The effective porosities were distributed through the 3D model volume using the GRFS method with upscaled effective porosity serving as primary input; this was collocated, co-kriged with the GR facies model (as secondary input) to produce the 3D effective porosity model (Figure 3-14). Unlike the kriging method that produces values that tighten towards the population's mean value, the GRFS method was selected because it can produce local variations (heterogeneity) that can fully honor the variance from the input (upscaled) porosity data while supervised by variogram statistics. Unlike kriging models where the output population gravitates to the mean of the input data, GRFS will model the full range of the input data by honoring both the minimum and maximum effective porosity values. The GRFS run produces just one equal probable geospatial distribution from an infinite number of possible solutions. 


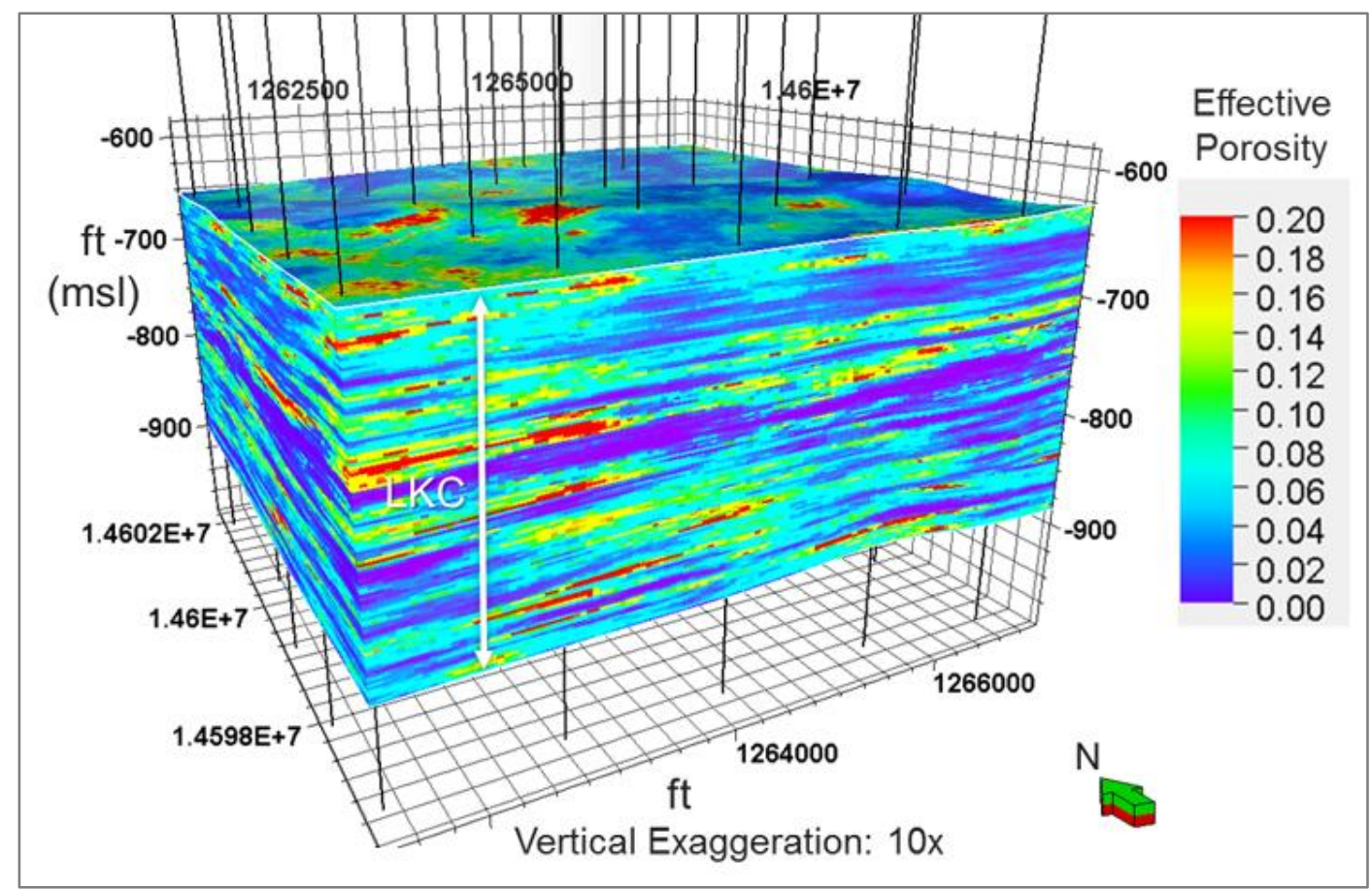

Figure 3-14. Effective porosity $\left(\phi_{e}\right)$ model. Porous LKC intervals correspond to carbonate units.

\section{7) Permeability Model}

3D permeability modeling was not explicitly used in the $\mathrm{CO}_{2}$ storage estimation method (Peck et al., 2014) employed in this paper. The permeability model had been included here as part of the customary SEM workflow and standard deliverable to reservoir engineers for conducting flow simulations (which have not been performed here).

Based on existing laboratory-measured core data, the permeability logs were derived from a power-law regression between core porosity and core permeability $\left(K=180.73 * \phi_{e}^{1.91}\right)$ (Battelle, 2019). This regression or fit was then used to calculate permeability logs from the effective porosity logs. The 3D permeability model was prepared in a three-step process: 1) The permeability logs at half-foot intervals were sampled (upscaled) into the model's two-foot layer grid along the vertical well trajectories using the harmonic mean method (Meyer, 1975) where the $\bar{x}=\frac{n}{\sum \frac{1}{x_{i}}}$. The harmonic mean upscaling method produces more representative estimates of permeability across vertical layers (Fouda, 2016). 2) The upscaled 
permeability logs were then distributed between wells and across the SEM using GRFS and were collocated, co-kriged with the effective porosity model as a secondary input to produce the 3D permeability model (Figure 3-15). This approach produced a 3D permeability model that spatially correlates to the effective porosity model.

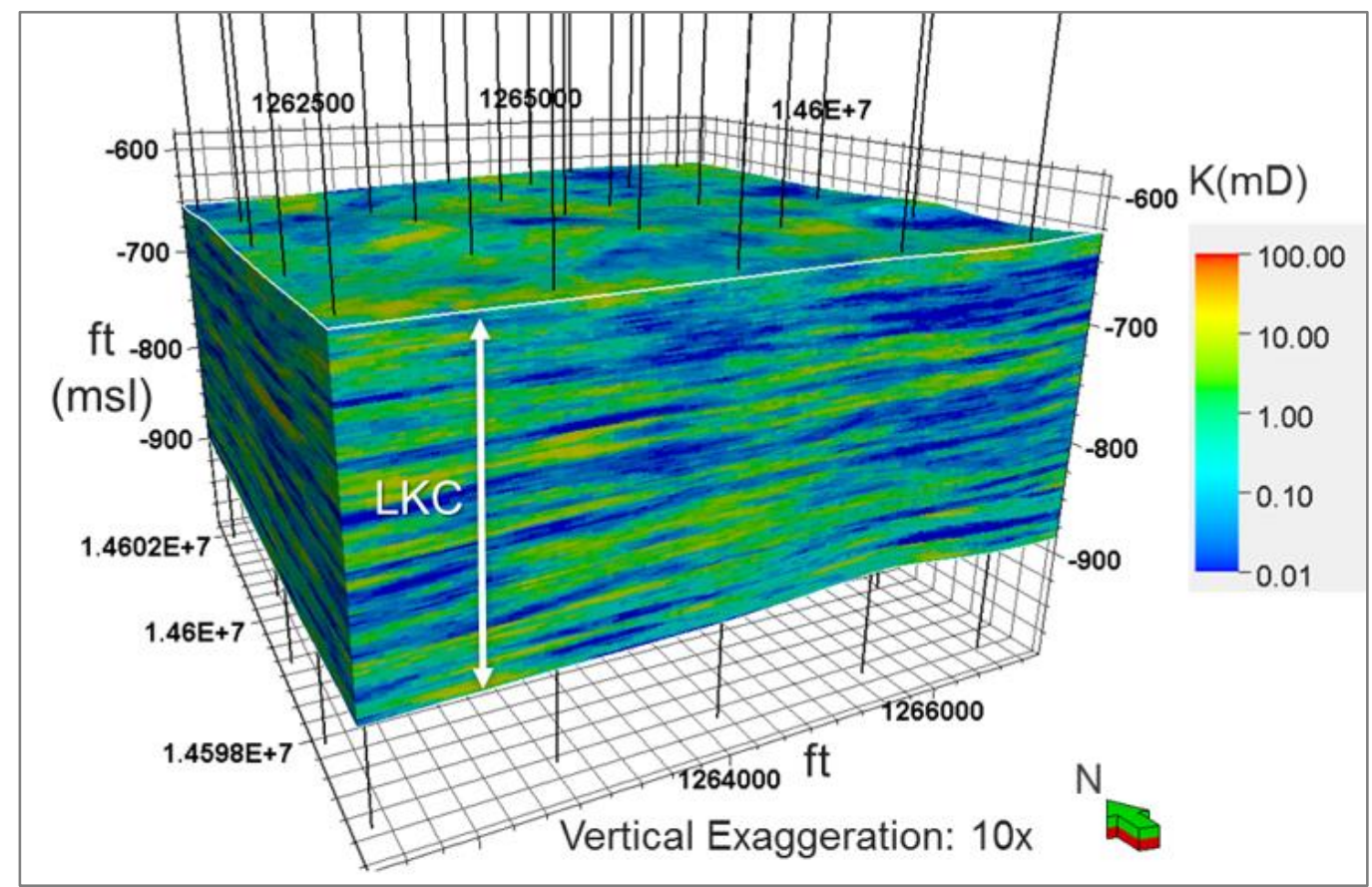

Figure 3-15. Permeability (K) model. Permeable LKC intervals correspond to limestone units.

\section{Storage Capacity Estimates}

For temperatures greater than $31.1^{\circ} \mathrm{C}\left(88^{\circ} \mathrm{F}\right)$ and pressures greater than $7.38 \mathrm{MPa}(1070.4 \mathrm{psi})$, the critical point, $\mathrm{CO}_{2}$ is in a supercritical state. Drill stem testing (DST) in the Wabaunsee Group, Oread, and the lower Marmaton Group produced data that was used to determine the reservoir temperature and pressure gradients (Figure 3-16). These gradients were then used to prepare temperature and pressure models within the 3D grid (Figure 3-17). The grid was then populated with a $\mathrm{CO}_{2}$ density model using a pressuretemperature lookup table from NETLCO2-SCREEN (Goodman et al., 2016). With increasing depth, the top and base of the $\mathrm{LKC}$ had the following range of reservoir conditions and $\mathrm{CO}_{2}$ density: 
Temperature: $93.8^{\circ} \mathrm{F}$ to $97.3^{\circ} \mathrm{F}\left(34.3^{\circ} \mathrm{C}\right.$ to $\left.36.3^{\circ} \mathrm{C}\right)$

Pressure: 1545 psi to $1730 \mathrm{psi}(10.65 \mathrm{MPa}$ to $11.93 \mathrm{MPa})$

Density: $743 \mathrm{~kg} / \mathrm{m}^{3}$ to $753 \mathrm{~kg} / \mathrm{m}^{3}\left(46.38 \mathrm{Lbs} / \mathrm{ft}^{3}\right.$ to $\left.47.00 \mathrm{Lbs} / \mathrm{ft}^{3}\right)$.

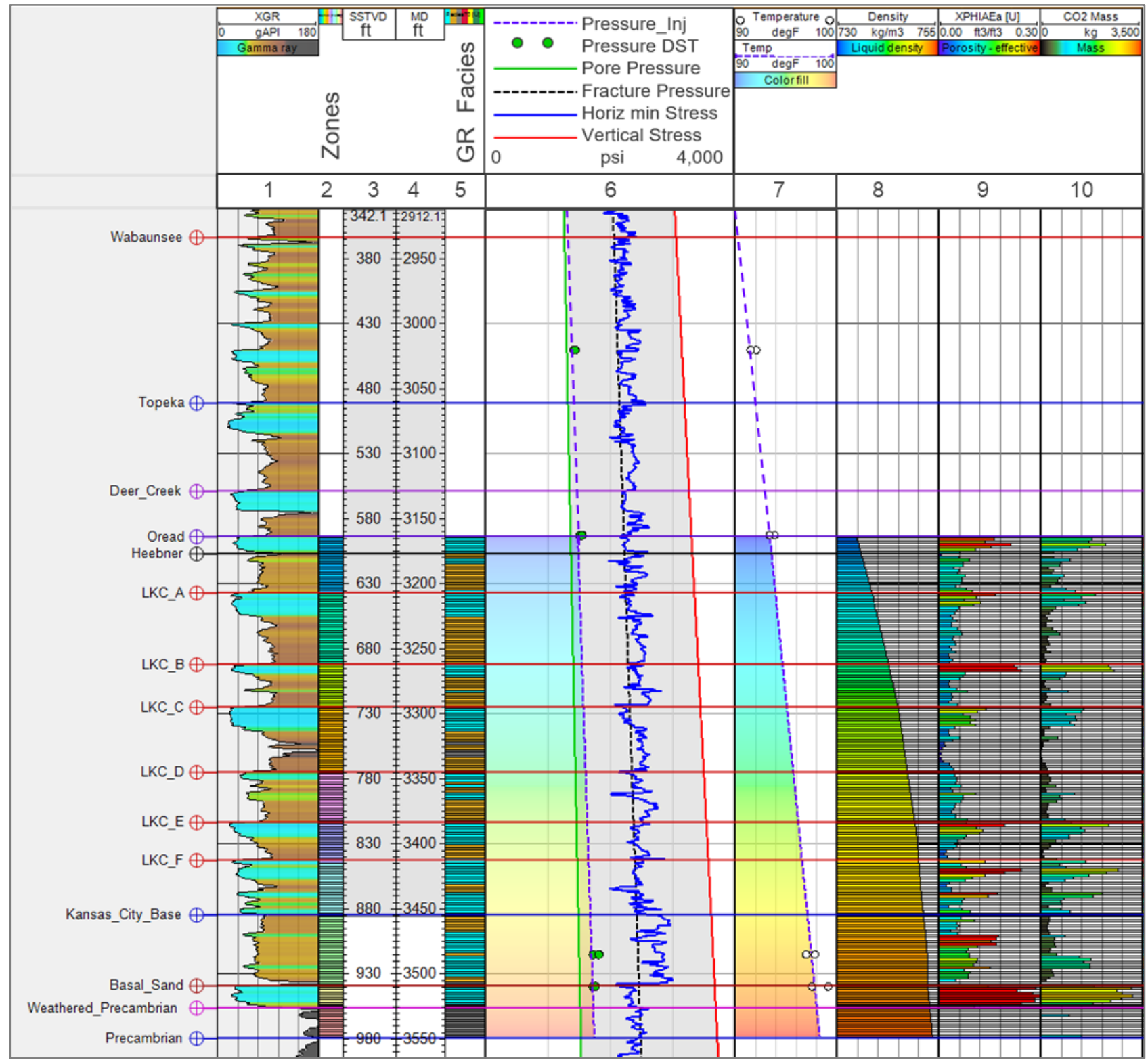

Figure 3-16. LKC pressure and temperature conditions from the SHRU 86A well. Track (1) Gamma ray log. (2) SEM zones. (3) and (4) are depth tracks. (5) GR facies log. (6) DST pressure points with implied formation pressure gradient. Also shown, pore pressure gradient, fracture pressure gradient, minimum horizontal stress, and vertical stress gradient. (7) Temperature points from DST implied formation temperature gradient. (8) Corresponding $\mathrm{CO}_{2}$ density passed on injection pressure (Pressure_Inj), and Temperature from tracks 6 and 7. (9) Upscaled effective porosity. (10) Computed $\mathrm{CO}_{2}$ mass in cells penetrated by SHRU 86A. 


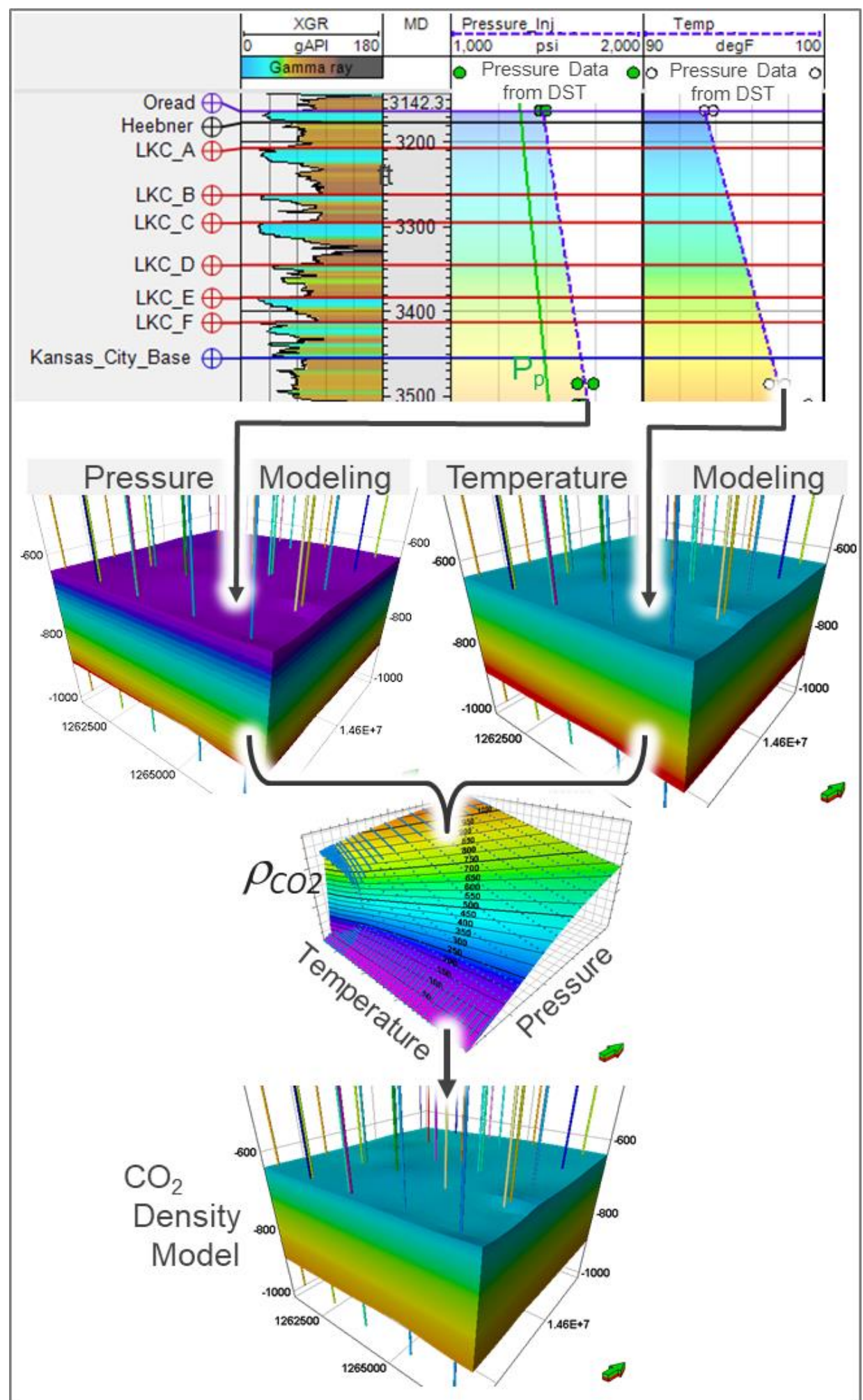

Figure 3-17. Workflow for $\mathrm{CO}_{2}$ density model. SHRU 86A pressure and temperature gradients are used to create pressure and temperature models. Pressure and temperature values are used cell-by-cell to obtain a $\mathrm{CO}_{2}$ density value via a look-up table expressed here as a contoured surface. 
The common method for calculating $\mathrm{CO}_{2}$ storage potential in saline formations is given by the following equation from Peck et al. (2014):

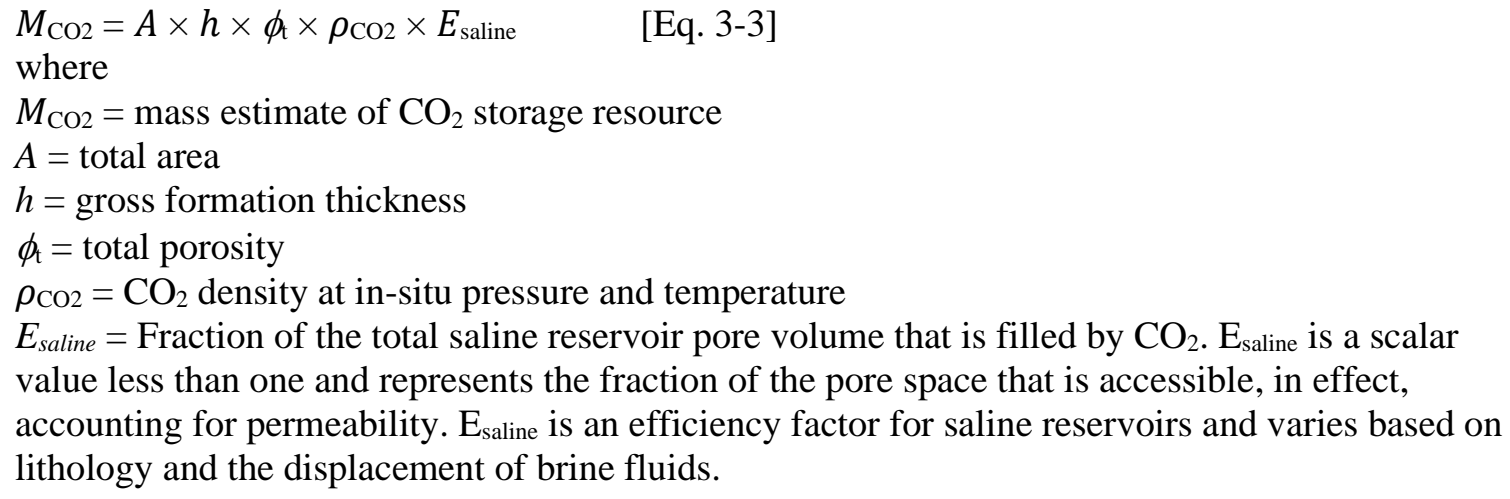

Equation 3-3 was adapted for use in a 3D geocellular model such that estimates of $\mathrm{CO}_{2}$ storage mass can be computed directly on individual cells and added together to produce $\mathrm{CO}_{2}$ storage mass estimates (Equation 3-4). Furthermore, because we use effective porosity rather than total porosity, and use GR facies to identify the reservoir rock, the storage efficiency factor is reduced (to just the displacement terms: $E_{\text {saline }}=\left(\mathrm{E}_{\mathrm{v}} * \mathrm{E}_{\mathrm{d}}\right)$ where $\mathrm{E}_{\mathrm{v}}$ is the volumetric displacement efficiency factor, and $\mathrm{E}_{\mathrm{d}}$, the microscopic displacement efficiency factor Peck et al. (2014). Because the area and thickness of the reservoir rock were well defined, we used $E_{\text {saline }}=0.1$, Peck et al. (2014). This represents the p10 level (a conservative estimate) for limestone. Thus, $M_{\mathrm{CO} 2}$ could be computed and reported by LKC zone and by GR facies, notably, our carbonate reservoir rock with GR facies code 0 , Table 3-3.

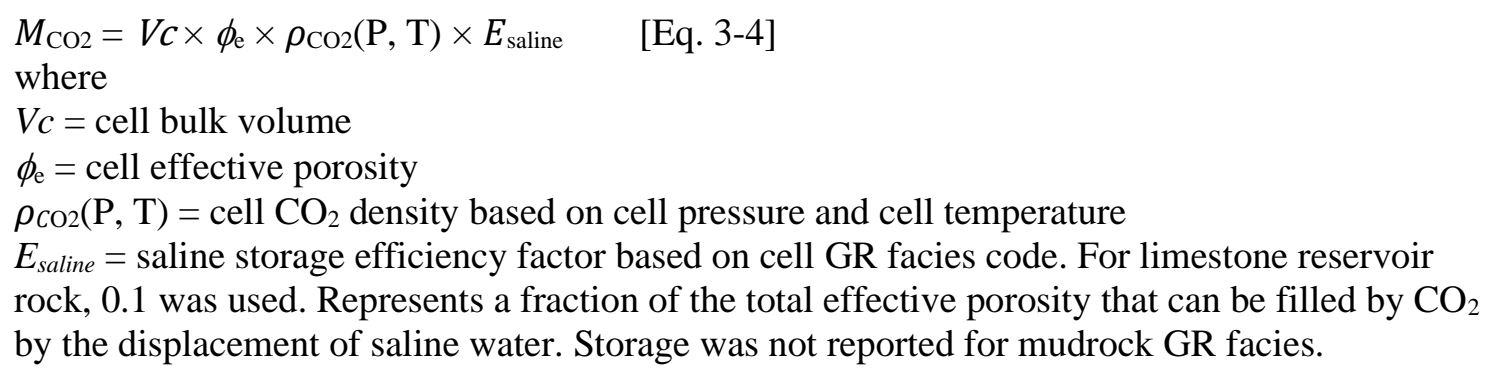


Finally, the $\mathrm{CO}_{2}$ storage resource estimate for the LKC was computed using the 3D SEM which included bulk volume $(V c)$, and models for effective porosity $\left(\phi_{\mathrm{e}}\right)$, Pressure $(\mathrm{P})$, Temperature $(\mathrm{T}), \mathrm{CO}_{2}$ Density $\left(\rho_{\mathrm{CO} 2}(\mathrm{P}, \mathrm{T})\right)$, and a storage efficiency factor of 0.1 for carbonate rock. Results are provided in Table 3-4 based on 1 square mile of LKC section at Sleepy Hollow Field. The calculation assumed that all units were saline and that the formations were accessible. While oil has been produced from some zones, this is a mature field where productive zones are progressively becoming more saline.

As anticipated, the storage of $\mathrm{CO}_{2}$ occupies the carbonate units and is partitioned by the mudrock units (Figure 3-18). Back calculations show that for an LKC carbonate lithology with GR facies code 0, the typical SEM cell $(50 \mathrm{ft} \times 50 \mathrm{ft} \times 2 \mathrm{ft})$ or $(15.4 \mathrm{~m}$ x $15.4 \mathrm{~m} 0.61 \mathrm{~m})$ holds an average of $856 \mathrm{~kg}$ of $\mathrm{CO}_{2}$ with an average effective porosity $\left(\phi_{\mathrm{e}}\right)$ of $8.62 \%$ and $\mathrm{E}_{\text {saline }}$ of 0.1 (Eq 3-4).

Table 3-4. Carbon storage resource estimates for the LKC carbonate reservoir units, GR facies code 0.

\begin{tabular}{cccc}
\hline LKC unit & $\begin{array}{c}\text { Effective } \\
\text { reservoir }(\%)^{*}\end{array}$ & $\begin{array}{c}\text { Tonnes } \\
\mathrm{CO}_{2} / \mathrm{mile}^{2}\end{array}$ & $\begin{array}{c}\text { Tonnes } \\
\mathrm{CO}_{2} / \mathrm{km}^{2}\end{array}$ \\
\hline LKC zone $\mathrm{A}$ & 37 & 89,591 & 34,591 \\
LKC zone B & 40 & 79,587 & 30,729 \\
LKC zone C & 38 & 116,636 & 45,033 \\
LKC zone D & 39 & 74,597 & 28,802 \\
LKC zone E & 54 & 85,686 & 33,084 \\
LKC zone $\mathrm{F}$ & 76 & 156,060 & 60,255 \\
\hline Total: & & 602,157 & 232,494 \\
\hline
\end{tabular}

* Percent of zonal volume comprised of limestone reservoir rock; the remaining zonal portion is either mudstone or shale. 


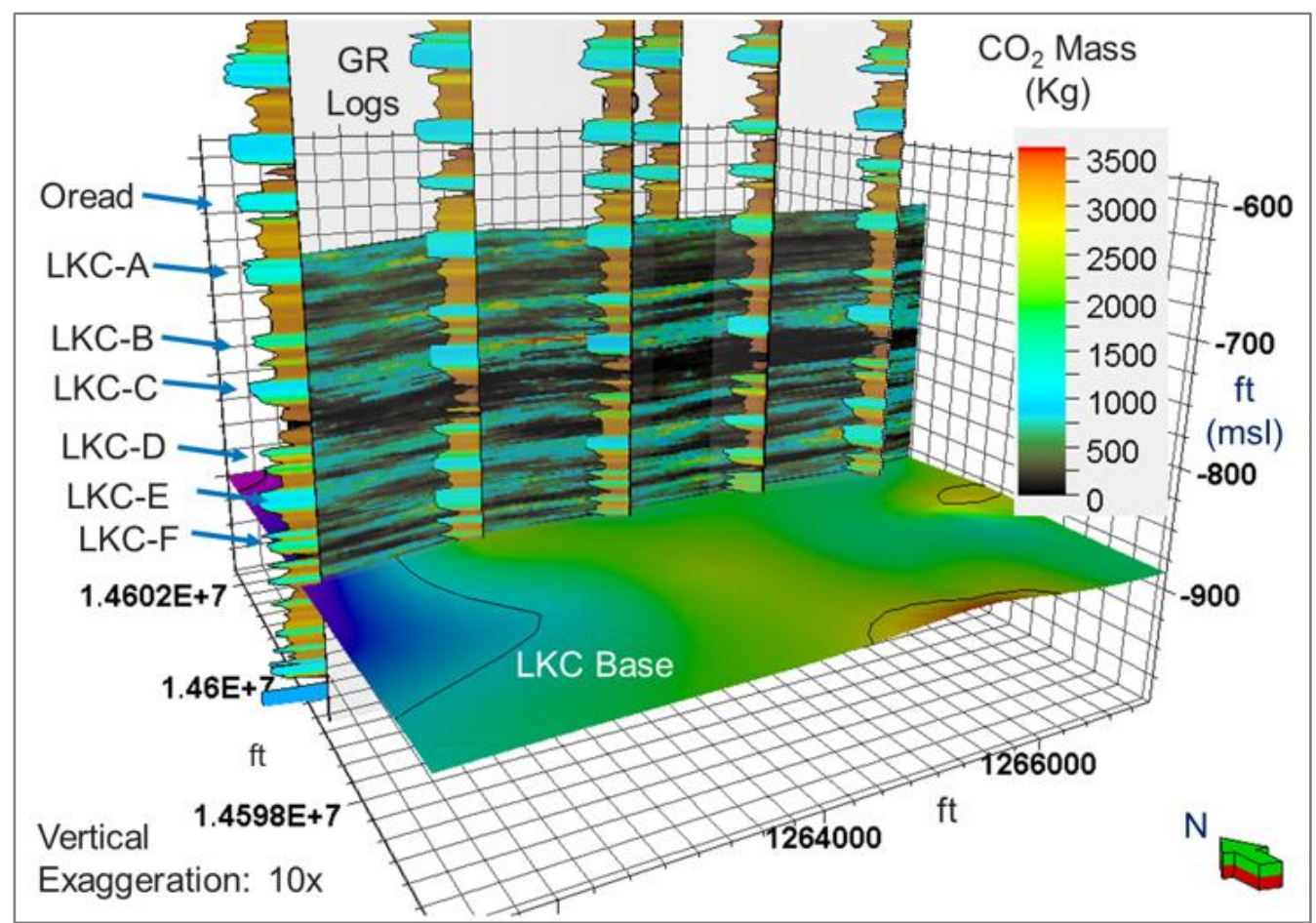

Figure 3-18. Slice through the SEM, showing the computed $\mathrm{CO}_{2}$ mass storage for the LKC. Dark areas represent mudstone intervals. Light areas represent computed $\mathrm{CO}_{2}$ storage based on $\mathrm{CO}_{2}$ density and reservoir pore space accessibility.

\section{Discussion}

Core examinations and petrography show that the carbonate units vary in composition. For modeling the LKC carbonate units, we combined oolite, packstone, grainstone, and wackestone limestone textures because these could not be resolved by well logs. We upscaled effective porosity within these GR $\log$ units to define available porosity.

We subdivided the log responses into three dominant lithologic subdivisions tagged by codes 0,1 , and 2. Intervals with GR log response less than 70 gAPI were assigned GR facies 0 (Table 3-3). This GR facies represents the carbonate intervals in the LKC where regressive limestones are the key porous units with the best opportunity for $\mathrm{CO}_{2}$ storage through interconnected porosity. We assigned GR values greater than 70 into two facies (1 and 2) that are associated with siliciclastic mudstone or shale; or if limestone is present, there is significant clay content occluding pore space. 
The $\mathrm{CO}_{2}$ storage estimates presented here were simplified by assuming that all LKC zones were saline. However, Sleepy Hollow is a mature oilfield that has produced oil from the LKC "zone C" and the basal sandstone. Oil shows are also present in LKC zones B and F. A more accurate determination of potential $\mathrm{CO}_{2}$ storage here would require a more rigorous analysis of water saturation for oil-bearing units.

The deterministic $\mathrm{CO}_{2}$ mass estimates produced here are comparable to those first produced by Battelle (2018) using NETLCO2-SCREEN (Goodman et al., 2016). The conservative saline efficiency factor of 0.1 reflects limitations to accessible pore volume in limestone and represents the combined volumetric displacement efficiency factor and the microscopic displacement efficiency factor.

The robust SEM prepared here has a fully integrated workflow and can be used to estimate potential $\mathrm{CO}_{2}$ storage. Accurate calculation of theoretical and practical $\mathrm{CO}_{2}$ storage capacity in mature oil fields depends on the accurate porosity and permeability estimation and geostatistical distribution of petrophysical properties. While permeability is an essential part of static earth modeling, it was not used in the $\mathrm{CO}_{2}$ estimates presented here as it does not explicitly fit into the equations from Peck et al. (2014) or the NETLCO2-SCREEN method (Goodman et al., 2016). However, this SEM, including the permeability model, can be used as direct input for dynamic reservoir modeling (DRM) or flow simulations. Conducted by reservoir engineers, DRM work is a more rigorous analytical treatment for estimating storage capacity and injectivity of the formations, and for testing different injection strategies. This method incorporates boundary conditions for the aquifer(s), injection pressure limitations, and assigns relative permeability curves, and perforation intervals, etc.

\section{Summary and Conclusions}

Well $\operatorname{logs}$ and core data were used to develop a static earth model representing the Upper Pennsylvanian Lansing and Kansas City groups at Sleepy Hollow Field, Nebraska. These data were supplemented with new data from the SHRU 86A drilled expressly for the IMSCS-Hub project. We divided the LKC into three basic units based on their gamma ray response: A GR facies model represented limestone reservoir intervals, and less permeable intervals comprised of mudstone and shale. This GR facies model 
was used as the framework for conditioning the 3D effective porosity model that was generated using GRFS guided by variogram analysis. We estimated $\mathrm{CO}_{2}$ storage volumes using a $3 \mathrm{D}$ geocellular grid in which each element is described by limestone reservoir rock volume, effective porosity, and $\mathrm{CO}_{2}$ density calculated as a function of pressure and temperature. We summarize $\mathrm{LKC} \mathrm{CO}_{2}$ storage volumes derived from the simulation in terms of storage mass per square mile. This can serve as a comparative benchmark for $\mathrm{CO}_{2}$ storage in the LKC group at other sites. The geologic interpretation and workflows developed in the study provide the basis for commercial $\mathrm{CO}_{2}$ storage efforts in vertically stacked saline zones along with combined storage through $\mathrm{CO}_{2}$-EOR in oil-bearing intervals of the Pennsylvanian LKC group.

From this study, we make the following conclusions:

1) $\mathrm{CO}_{2}$ storage opportunities in the Pennsylvanian LKC group are limited to thin (2 to 22 feet thick $(0.61-6.7 \mathrm{~m}))$ limestone units that are overlain by mudrocks. These limestones may be mostly wackestones and carbonate mudstones, but oolitic limestone, skeletal, and peloidal grainstones are also present and offer the most favorable porosity values. The mudrock units are tight and have acted as barriers to oil migration; these can also serve as barriers to upward $\mathrm{CO}_{2}$ fluid migration. Lateral $\mathrm{CO}_{2}$ migration within the carbonate units is expected and necessary. Based on project size, flow simulations would be required to develop an injection strategy and delineate the $\mathrm{CO}_{2}$ plume area.

2) The "Kansas-type" cyclothem model provides a practical basis for understanding the LKC carbonate succession. Unlike the outcrop-based model proposed by previous authors, the LKC sedimentation across the Cambridge Arch does not include significant transgressive marine shale intervals; they are frequently absent or too thin to be detected in the GR logs.

3) Sleepy Hollow Field has over 200 wells with gamma ray $\operatorname{logs}$; 26 wells within the SEM footprint. We used the GR response to partition the LKC section into three key lithologies. The low response to clean carbonates (GR $<70$ gAPI) differentiates limestone units from the mudrock-dominated 
intervals. Mudstones intervals generally occur (70 < GR < 120 gAPI), and the fissile, darker shale units that correlate to transgressive marine shale occur where GR logs are great than 120 gAPI.

4) Neutron porosity logs provide good estimates of effective porosity in clean limestone units. In contrast, clay-bound water in mudrock-dominated units requires significant corrections to produce an effective porosity for these intervals. Calibrating effective porosity and permeability logs requires laboratory core data. Mudrock intervals had the lowest permeability of $\sim 0.001 \mathrm{mD}$ and, therefore, very low effective porosities. Limestone intervals have higher permeabilities and effective porosities.

5) Gamma ray logs alone cannot be used to identify individual limestone textures.

6) The limestones are thin, and their low effective porosity limits $\mathrm{CO}_{2}$ storage in the LKC group. Nevertheless, the model developed in this study reveals the significant potential for regional storage in and around existing, mature oilfields.

7) At Sleepy Hollow Field, the conservative p10 estimate of supercritical $\mathrm{CO}_{2}$ storage potential is 602,157 tonnes/ mile 232,494 tonnes $\left./ \mathrm{km}^{2}\right)$. The estimate incorporated a saline storage efficiency factor, $\mathrm{E}_{\text {saline}}$, of 0.1 . A conservative estimate has been offered here because the carbonate zones here generally have permeability less than $10 \mathrm{mD}$.

8) Based on an estimated Sleepy Hollow Field size of $14 \mathrm{miles}^{2}$, the LKC in this area can potentially store 8.43 million tonnes $(\mathrm{Mt})$ of $\mathrm{CO}_{2}$ under saline reservoir conditions.

The presence of oil will affect the estimates reported here, but the numbers are representative of saline storage potential in Red Willow County, NE. Storage estimates for the LKC can vary regionally depending on carbonate thickness and carbonate reservoir quality, but estimates produced here should be useful on the Cambridge Arch.

The permeability model was not used in the $\mathrm{CO}_{2}$ storage estimate because it does not explicitly fit into the NETLCO2-SCREEN software tool (Goodman et al., 2016). Its intended use is for conducting flow simulations by reservoir engineers. Although $\mathrm{CO}_{2}$ flow simulations have not been conducted in this paper, 
flow simulations representing the full Pennsylvanian section have been completed by Battelle (2018 and 2019).

Ongoing work involves laboratory measurements on new core samples, and opportunities remain for the refinement of effective porosity logs and the development of accurate permeability logs (Battelle, in progress 2020). Laboratory-based NMR measurements on core samples may provide new data to better calibrate effective porosity logs. More robust treatment of $\mathrm{CO}_{2}$ storage estimates in the $\mathrm{LKC}$ would require further characterization of oil-bearing intervals. Additionally, a probabilistic treatment of the storage efficiency factors would yield estimated storage results for p10, p50, and p90. A workflow is currently being developed as part of an integrated solution for determining storage without the need to distill the SEM down to 300-cells for use in the NETLCO2-SCREEN software tool (Goodman et al., 2016) that has commonly been used by regional $\mathrm{CO}_{2}$ storage partnerships. 


\section{Acknowledgments}

The research for the Integrated Mid-continent Stacked Carbon Storage Hub project is supported by the U.S. Department of Energy - National Energy Technology Laboratory Agreement No. DE-FOA0031623 and No. DE-FE0029264. The data supplied in this study were acquired in collaboration with the Conservation and Survey Division, School of Natural Resources, University of Nebraska-Lincoln, and through Great Plains Energy, Inc., Lincoln, NE. Existing oilfield data was acquired through the Nebraska Oil and Gas Commission and the Kansas Geological Survey Oil and Gas database.

\section{References Cited}

Asquith, G. and Krygowski, D., 2006, Basic Well Log Analysis, Second Edition, AAPG, ISBN:9780891816676, $244 \mathrm{p}$.

Battelle Memorial Institute, 2018, Integrated Mid-Continent Stacked Carbon Storage Hub, Task 3 SubBasinal Geologic Assessment Topical Report, DOE Agreement/Project \# DE-FE0029264

[ https://www.osti.gov/biblio/1478726-integrated-mid-continent-stacked-carbon-storage-hub-phase-finalreport ]

Battelle Memorial Institute, 2019, Integrated Mid-Continent Stacked Carbon Storage Hub Project Phase II, Task 3 Feasibility Data Collection Planning, DOE Agreement/Project \# DE-FE0031623

Dubois, M. K., 1985, Application of cores in development of an exploration strategy for the LansingKansas City "E” zone, Hitchcock County, Nebraska: Kansas Geological Survey, Subsurface Geology Series 6, p. 120-132.

Evans, D. G, and Steeples, D. W., 1987, Microearthquakes Near the Sleepy Hollow Oil Field, Southwestern Nebraska: Bulletin of the Seismological Society of America, v. 77, no. 1, p. 132-140.

Fielding, C.R. and Joeckel, R.M., Compilers, 2018, New Insights into Carboniferous Cyclothems. The Fourth Biennial Field Conference of the American Association of Petroleum Geologists (AAPG) Midcontinent Section Fourth Biennial Field Conference Abstracts and Guidebook University of Nebraska - Lincoln, Conservation and Survey Division, 68 p.

Fouda, M. A. G., 2016, Relative Permeability Upscaling for Heterogeneous Reservoir Models, Dissertation, Heriot-Watt University, Edinburgh, Scotland, 160 p.

Goodman, A., Sanguinito, S., Levine, J., 2016. Prospective CO2 resource estimation methodology: Refinement of existing US-DOE-NETL methods based on data availability: International Journal of Greenhouse Gas Control, v. 54, p. 242-249.

Heckel, P. H., 1991, Thin widespread Pennsylvanian black shales of the Midcontinent North America: a record of cyclic succession of widespread pycnoclines in a fluctuating epeiric sea: Geological Society Special Publication, no 58, p. 259-273. 
Heckel, P. H., 1986, Sea-level curve for Pennsylvania eustatic marine transgressive-regressive depositional cycles along midcontinent outcrop belt, North America: Geology, v.14, p. 330-334.

Heckel, P. H., 1994, Evaluation of evidence for glacio-eustatic control over marine Pennsylvanian cyclothems in North America and consideration of possible tectonic effects: SEPM, Concepts in Sedimentology and Paleontology \#4, p. 65-87.

Heckel, P. H., and Watney, W. L., 2002, Revision of Stratigraphic Nomenclature and Classification of the Pleasanton, Kansas City, Lansing, and Lower Part of the Douglas Groups (Lower Upper Pennsylvanian, Missourian) in Kansas: Kansas Geological Survey Bulletin 246.

Heckel P. H., 2008, Pennsylvanian cyclothems in Midcontinent North America as far-field effects of waxing and waning of Gondwana ice sheets, in Fielding C.R. Frank T.D. Isbell J.L., eds., Resolving the Late Paleozoic Ice Age in Time and Space: Geological Society of America Special Paper 441 , p. 275289.

Joeckel, R.M., 1989, Paleogeomorphology of a Pennsylvanian land surface: The Rock Lake Shale in Nebraska: Journal of Sedimentary Petrology, v. 59, p. 469-481.

Joeckel, R.M., 1994, Virgilian (Upper Pennsylvanian) Paleosols in the Upper Lawrence Formation (Douglas Group) and in the Snyderville Shale Member (Shawnee Group, Oread Formation) of the Northern Midcontinent, U.S.A.: Pedologic Contrasts in a Cyclothem Sequence: Journal of Sedimentary Research v. A64, p. 853-866.

Joeckel, R.M., 1999, Paleosol in Galesburg Formation (Kansas City Group, Upper Pennsylvanian), northern Midcontinent, U.S.A.: Evidence for climate change and mechanisms of marine transgression: Journal of Sedimentary Research, v. 69, p. 720-737.

Meyer, S.L., 1975, Data Analysis for Scientists and Engineers, Wiley, First Edition, 513 p.

Moore and Nelson, 1974, Effect of Cambridge-Chadron Structural Trend on Paleozoic and Mesozoic Thickness, Western Nebraska: AAPG Bulletin, v. 58, p. 260-268.

Peck, W. D., Glazewski, K. A., Klenner, R. C. L., Gorecki, C. D., Steadman, E. N., and Harju, J. A., 2014, A workflow to determine CO2 storage potential in deep saline formations: Energy Procedia, v. 63, p. 5231-5238.

Prather, B. E., 1985, Depositional facies and diagenetic fabrics of the D-Zone cyclothem, Lansing-Kansas City groups, Hitchcock County, Nebraska: Kansas Geological Survey, Subsurface Geology 6, p. 133144.

Rogers, J. P., 1977, Genesis and Distribution of Desmoinesian (Pennsylvanian) Sandstone Reservoir, Sleepy Hollow Field, Red Willow County, Nebraska: The AAPG Bulletin, v. 61, no. 7, p. 1029-1044.

Schlumberger, 2020, Elemental capture spectroscopy sonde, https://www.slb.com//media/files/fe/brochure/ecs-brochure (accessed, February 8, 2020)

Steeples, D. W., 1982, Structure of the Salina-Forest City interbasin boundary from seismic studies: Kansas Geological Survey Bulletin 226, Geophysics in Kansas, p. 31-52. 
Watney, W. L, 1980, Cyclic sedimentation of the Lansing-Kansas City Groups in northwestern Kansas and southwestern Nebraska: Kansas Geological Survey, Bulletin 220.

Young, A. L., 2011, Lithostratigraphy and Diagenesis of the Upper Pennsylvanian (Missourian) LansingKansas City Groups in Rooks County, Kansas, Master's thesis, Wichita State University, Wichita, Kansas, 30p.

Zhao, J., Chen, H., Yin, Lu., and Li, N., 2017, Mineral inversion for element capture spectroscopy logging based on optimization theory, Journal of Geophysics and Engineering, vol. 14, Issue 6, December 2017, p. 1430-1436. 


\title{
Chapter 4: Static Earth Modeling and $\mathrm{CO}_{2}$ Storage in Lansing and Kansas City Groups, Huffstutter Field, Kansas, USA
}

\begin{abstract}
The main objective of this study was to estimate carbon dioxide storage potential of the interbedded shales and carbonates in the Pennsylvanian Lansing - Kansas City (LKC) Groups on the Central Kansas Uplift in Phillips County, Kansas. I develop a Static Earth Model based on a gamma ray log facies to define carbonate porosity among the confining shale units in the LKC Groups. The results of this effort are essential to the development of a $\mathrm{CO}_{2}$ storage strategy for the Integrated Midcontinent Stacked Carbon Storage (IMSCS) Hub Project as part of DOE-NETL's Carbon Storage Assurance Facility Enterprise (CarbonSAFE) initiative. Carbon sequestration potential is estimated using a static earth model (SEM) for Huffstutter Field, Philips County, Kansas.
\end{abstract}

The $\mathrm{LKC} \mathrm{CO}_{2}$ storage estimate for the Huffstutter SEM was 443,355 tonnes $\mathrm{CO}_{2} / \mathrm{mile}^{2}(171,180$ tonnes $\mathrm{CO}_{2} / \mathrm{km}^{2}$ ) and represented about $75 \%$ of that obtained for the Sleepy Hollow Field which was estimated at 602,157 tonnes $\mathrm{CO}_{2} /$ mile $^{2}\left(232,494\right.$ tonnes $\left.\mathrm{CO}_{2} / \mathrm{km}^{2}\right)$. While Huffstutter has thicker LKC limestone reservoir rock units, the potential for storage in the LKC at Sleepy Hollow appears better due to larger effective porosity in its limestone units. The Huffstutter SEM indicates that the $\sim 216$-foot LKC section would need to be supplemented by both overlying and underlying Pennsylvanian carbonates to meet NETL's 50 million metric tonne $\mathrm{CO}_{2}$ storage target over a 30-year period.

This analysis quantifies the $\mathrm{CO}_{2}$ storage potential in vertically stacked carbonates of the LKC and is representative of Pennsylvanian cyclothems. The SEM developed here can help in decisions regarding the placement of an injection well, evaluation of new log data, and real-time assessment of injection performance. With the modification of storage efficiency factors, the model can be used to address $\mathrm{CO}_{2}$ storage in the presence of oil; the model can also be refined for use in CO2-EOR for oil-bearing intervals. 


\section{Introduction}

The Integrated Midcontinent Stacked Carbon Storage (IMSCS) Hub Project is part of DOE-NETL's Carbon Storage Assurance Facility Enterprise (CarbonSAFE) initiative. The purpose of this project is to develop a regional carbon storage hub that would connect sources of captured carbon to existing oilfields for carbon storage and enhanced oil recovery (EOR). This research supports the assessment of geologic $\mathrm{CO}_{2}$ storage for sites in Nebraska and Kansas. This Huffstutter site was selected because it is located on a geographic corridor near significant $\mathrm{CO}_{2}$ sources to the northeast (corn ethanol plants) and potential $\mathrm{CO}_{2}$ sinks (mature oilfields) to the southwest. Furthermore, the site offers potential reservoir units and seals that are determined to be of sufficient depth and quality for $\mathrm{CO}_{2}$ storage. Reservoir characterization began with the collection of existing well logs from Huffstutter Field that were digitized. Subsurface interpretation and reservoir characterization served as the basis for the Static Earth Model (SEM) of the Pennsylvanian Lansing - Kansas City (LKC) Groups cyclic carbonate intervals. Existing core samples from Sleepy Hollow Field to the northwest and the Dopita A-16 well to the south were studied and show that porosity occurs in limestone textures that include packstone, grainstone, and oolitic units. Analysis of log responses from gamma ray (GR) and neutron porosity (NPHI) logs reveals LKC interbedded shales and carbonates are cyclical in occurrence consistent with the "Kansas-type" cyclothem as described by Heckel (1986). The GR log was employed in SEM facies development to delineate limestone, mudrock, and shale using GRthresholds. For effective porosity, the use of NPHI logs required discriminating the clean limestones (reservoir units) from the mudrocks (seals). Apparent porosity in mudrocks is attributed to clay-bound water.

This work integrates existing data to form an SEM. Well logs, such as gamma ray (GR) and neutron

porosity (NPHI), revealed cyclicity among the carbonate units. Interpretations from core samples showed that the rock units could generally be lumped into three categories: limestone-dominant, mudstonedominant (commonly massive or blocky but not platy), and shale-dominant (commonly fissile) rock. Together, these three categories represent the fundamental facies for developing the SEM. GR logs were 
commonly available for the field, and their distinctive response is associated with these three categories. GR log thresholds were used to delineate these facies. For the purpose of SEM development, these three classes characterize the major stratigraphic characteristics of the LKC Groups and represent important differences in reservoir (or seal) quality. NPHI logs were not as common as the GR logs and were used in the petrophysical modeling step. The NPHI logs indicate high porosity for the mudrock-dominant intervals due to the presence of clay-bound water. In general, the presence of clay-bound water complicated the interpretation of NPHI log response throughout the LKC Groups. The derivation of effective porosity logs for these formations was a key issue during SEM development.

\section{Objective and Purpose}

The objective of this research is to characterize the reservoirs and seals within the LKC group at Huffstutter Field, Philips County, Kansas. The LKC represents both saline and hydrocarbon units throughout the area. The purpose of this work is threefold: 1) develop a 3D, Static Earth Model representing the petrophysical properties of these units so that, 2) a quantitative $\mathrm{CO}_{2}$ storage assessment can be performed on the reservoir units. 3) Compare the LKC storage results for Huffstutter Field against those obtained for Sleepy Hollow Field, as reported in Chapter 3. The reservoir characterization and SEM workflows prepared here serve the broader needs of the IMSCS-Hub Project.

\section{Geologic Setting}

Huffstutter oilfield is the largest field in Philips County (Figure 4-1a), where many mature oilfields are still active. The largest structural trend in the area is the Central Kansas Uplift, a southeasterly continuation of the Cambridge Arch located northwest in Nebraska. Together, these structural uplifts trend from the northwest to the southeast (Figure 4-1a). Huffstutter Field (HF), the focus of this paper, is located on a very gentle anticline along the eastern portion of the Central Kansas Uplift. Huffstutter contains more than 100 wells, and a subset of these was digitized for use in this study (Figure 4-1b). Most of these wells stop at or near the base of the Kansas City Group as oil production for HF has been from the LKC stratigraphic zones "E" and "F," (Figure 4-2). In this field, a few wells have penetrated deeper into the 
Arbuckle Limestone (Figure 4-2). Unlike Sleepy Hollow Field to the NW, there is no evidence of a basal sandstone. Given the limited well coverage to basement here, it is unclear whether the Cambrian Reagan Sandstone is present.

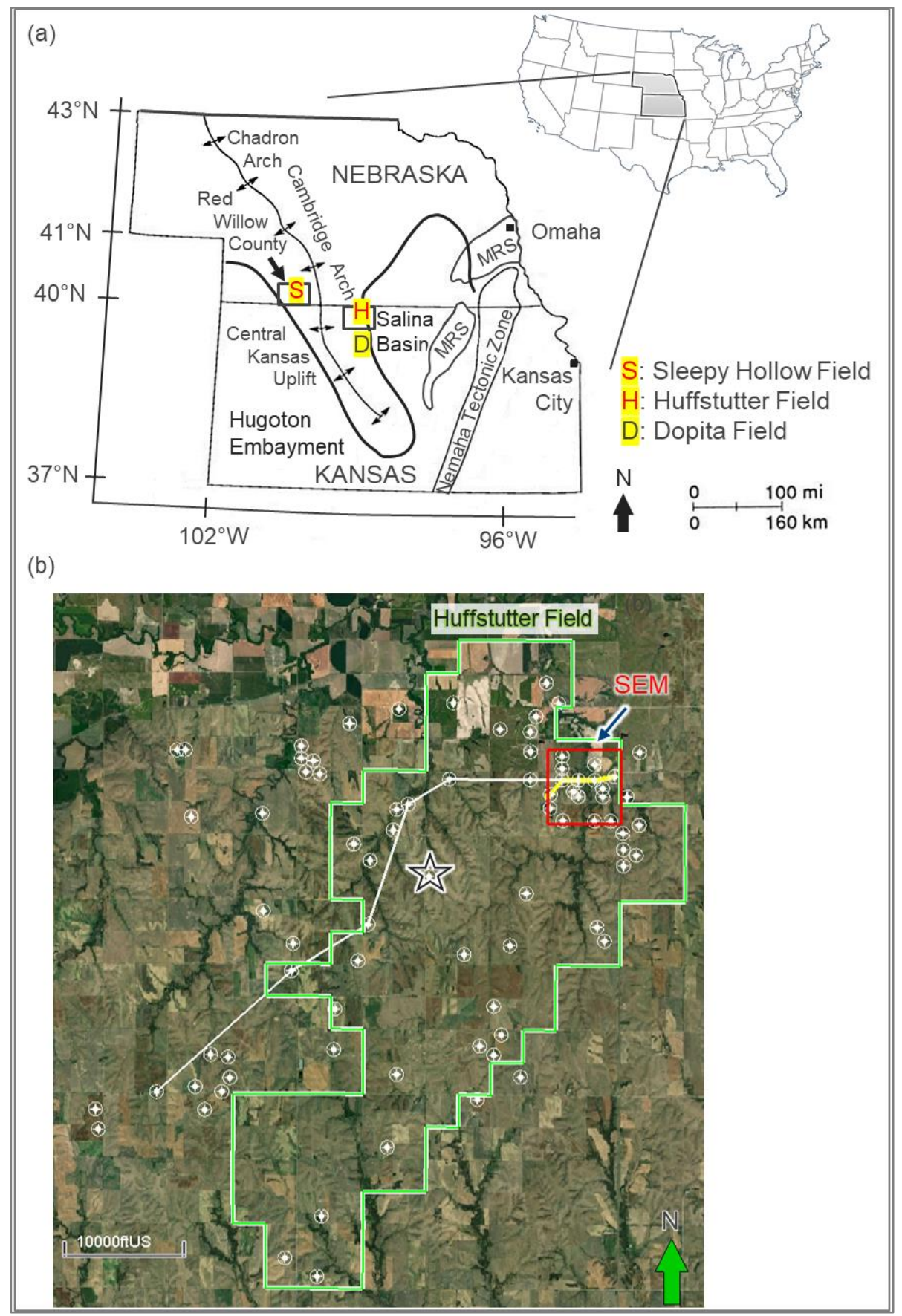

Figure 4-1. (a) Location of Huffstutter Field on the east limb of the Central Kansas Uplift (modified after Steeples, 1982). (b) Huffstutter Field study area outlined by a green polygon. Wells collected for this study are shown as white circles. White stippled line: well section (see Figure 4-3). The red box represents the SEM footprint reported in this paper. The star is the location of the Schluntz \#10 well (see Figure 4-2). 
The preliminary target reservoirs for $\mathrm{CO}_{2}$ sequestration in the Pennsylvanian LKC Groups consist of stacked carbonate rocks. Some of these limestones produce petroleum, and others are saline, both are considered potential target reservoirs for $\mathrm{CO}_{2}$ sequestration in this study (Figure 4-2). The Pennsylvanian system is dominated by cyclic packages of carbonates and mudrocks, the origins of which are attributed to glacioeustatic sea-level fluctuations in shallow seas on an epicontinental platform. Assessment of the potential $\mathrm{CO}_{2}$ storage capacity within these carbonates using static earth modeling is the central theme of this paper. Within these cyclothems, the limestone units are sealed by tighter mudrock units, which separate the comparatively porous carbonate intervals. The basic well log suite common to many of the wells in the Huffstutter Field (Figure 4-1b) consists of gamma ray (GR), neutron-porosity (NPHI), and resistivity (R) logs. Core data was not available from the Huffstutter Field. Instead, core interpretations available from the Sleepy Hollow Field and Dopita Field (Dopita A-16 well) and their correlation to log responses serve as the basis for interpretations of LKC rock composition in the Huffstutter Field. 


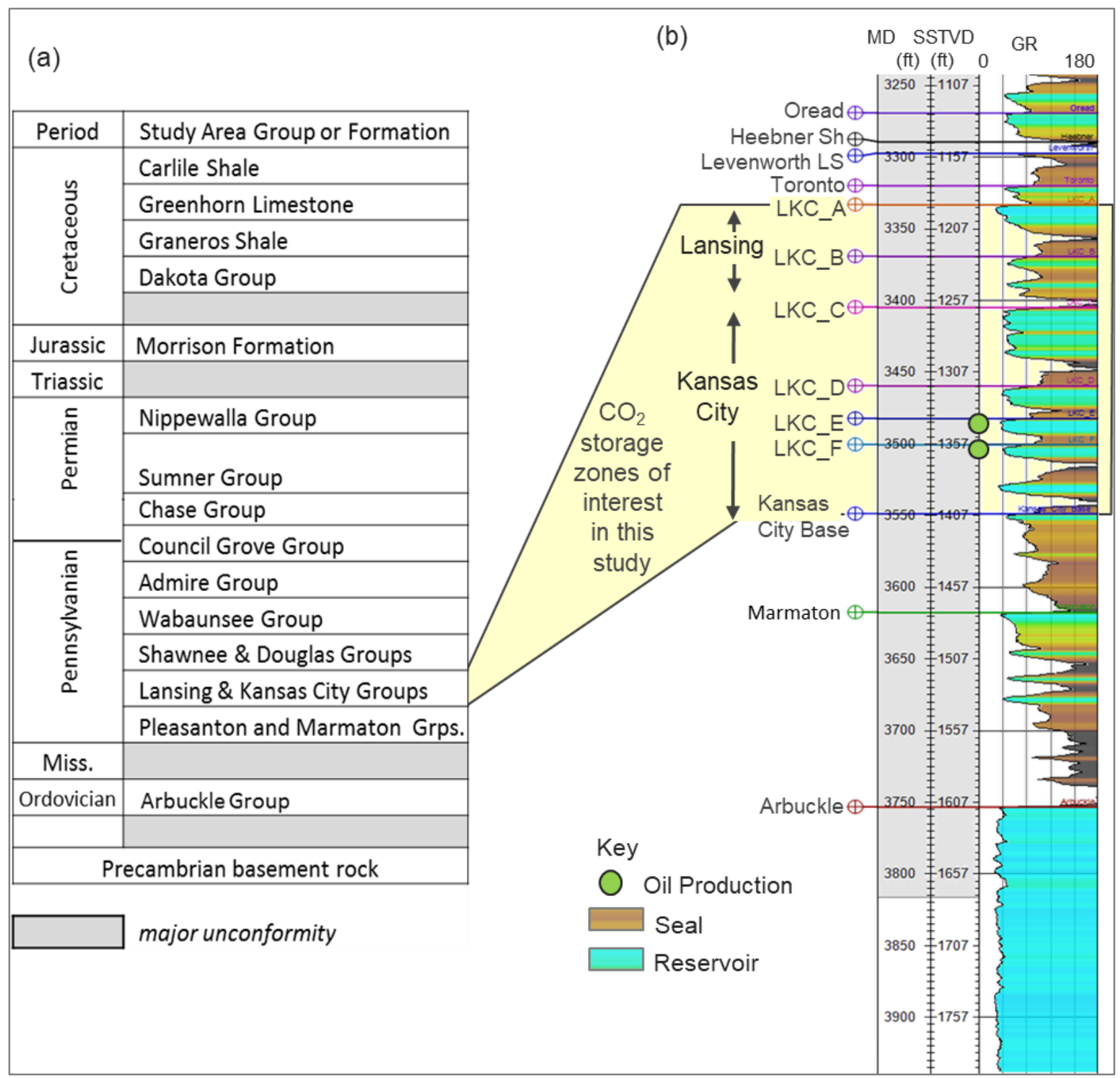

Figure 4-2. (a) Simplified stratigraphic column showing the deep saline formations of interest and overlying caprocks evaluated in the Huffstutter Field study area. (b) Example of gamma ray log response for members of the Lansing and Kansas City Groups. Well: Schluntz \#10, API: 1514720375, Figure 4-1.

Wells across the Huffstutter Field were commonly drilled to the base of the LKC at an approximate depth of 3,507 ft (1,068 m) (Figure 4-3). Correlations reveal the cyclic pattern of carbonate deposition throughout the field. The top of the LKC lies at an approximate depth of 3,290 $\mathrm{ft}(1003 \mathrm{~m})$ and has a thickness of about $216 \mathrm{ft}(65.8 \mathrm{~m})$ within the SEM footprint. The LKC was subdivided by well drillers into 
stratigraphic zones " $A$ " through " $\mathrm{K}$ " in Kansas. The " $A$ " through "F" convention common to southwestern Nebraska was adopted in this study as part of a regional correlation with Sleepy Hollow Field approximately 55 miles $(88.5 \mathrm{~km})$ to the northwest (see Chapter 2). The thickness of stratigraphic zones in the LKC ranges from $18 \mathrm{ft}$ to $53 \mathrm{ft}$ in thickness (5.5 m to $16.2 \mathrm{~m}$ ). Each zone is comprised of carbonates (oolite, packstone, peloidal, and skeletal grainstones, plus other, less porous textures like lime-mudstone) and mudrocks (siliciclastic mudstones and shales). Some of these lithologies are tight; therefore, each carbonate zone has storage restrictions determined by the magnitude and stratigraphic distribution of porosity. The interpreted base of the LKC (commonly labeled the "Kansas City Base") represents the undifferentiated top of either the Pleasanton or Marmaton Groups (Figure 4-2). The SW-to-NE well section (Error! Reference source not found.) shows the stratigraphic correlation of cyclical carbonate deposits across the field. The gamma ray signature indicates significant continuity for most stratigraphic features, especially for carbonate intervals with lower mud fraction.

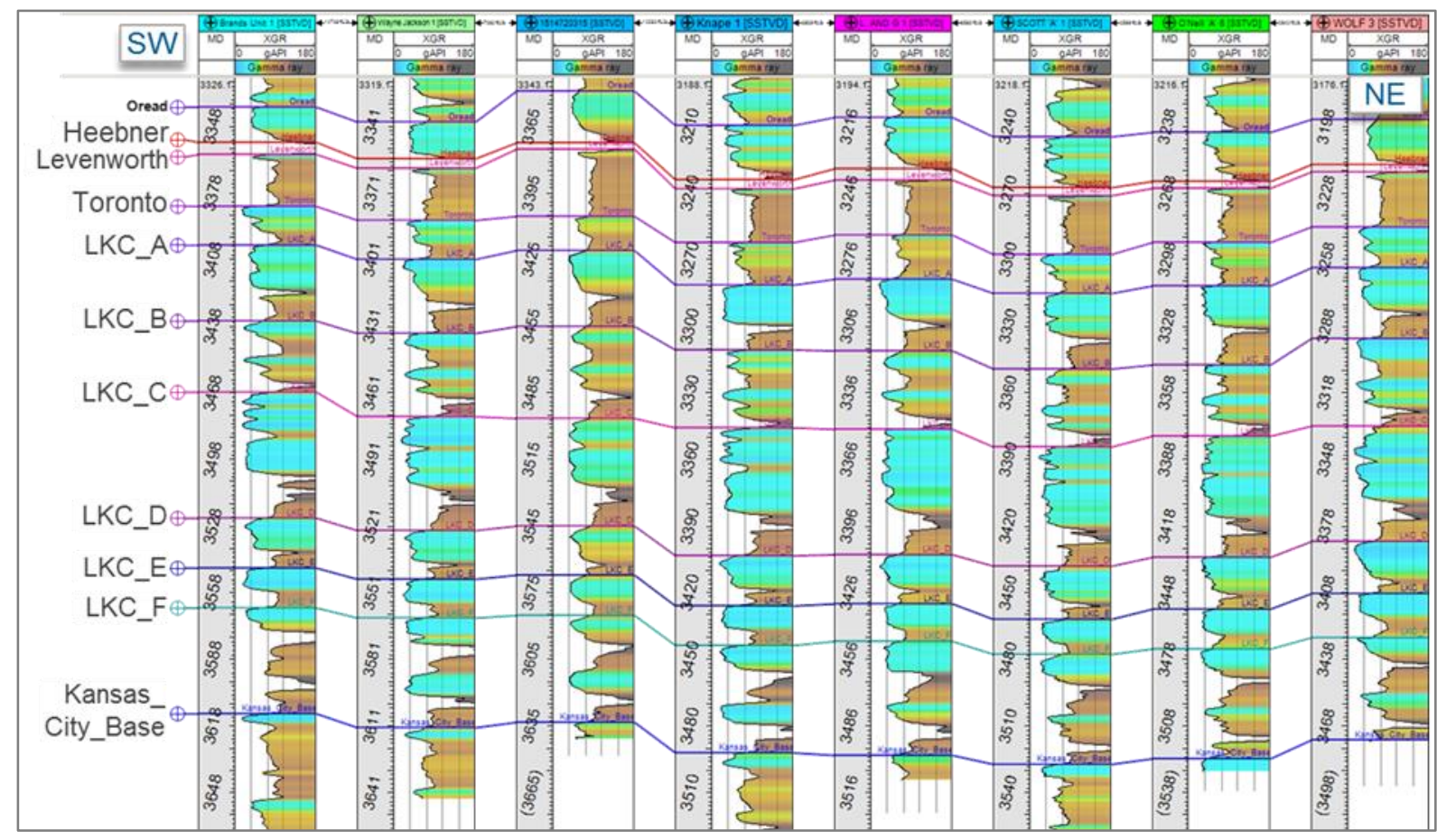

Figure 4-3. Log cross-section showing carbonate cyclicity observed in gamma ray well logs correlated across the Huffstutter study area. LKC zones are picked on top of key carbonate units. Log signatures indicate significant continuity of formations. The map in Figure 4-1 shows the cross-section's location. 
The gentle geologic structure in the Huffstutter Field is obtained from LKC zone top picks. Structural mapping of the top of the LKC “A” (equivalent to the Lansing Group's South Bend Limestone), reveals a gentle anticlinal structure in the study area (Figure 4-4). Many Phillips County wells follow the axis of this anticline towards the southwest. Although the LKC is considered the primary storage section for this study, storage opportunities may exist in overlying cyclothems of the Wabaunsee, Shawnee, and Douglass Groups, and deeper in the underlying Arbuckle Limestone. The Arbuckle here is poorly understood as there are very few penetrations deeper than the base of the Kansas City Group in Huffstutter Field.

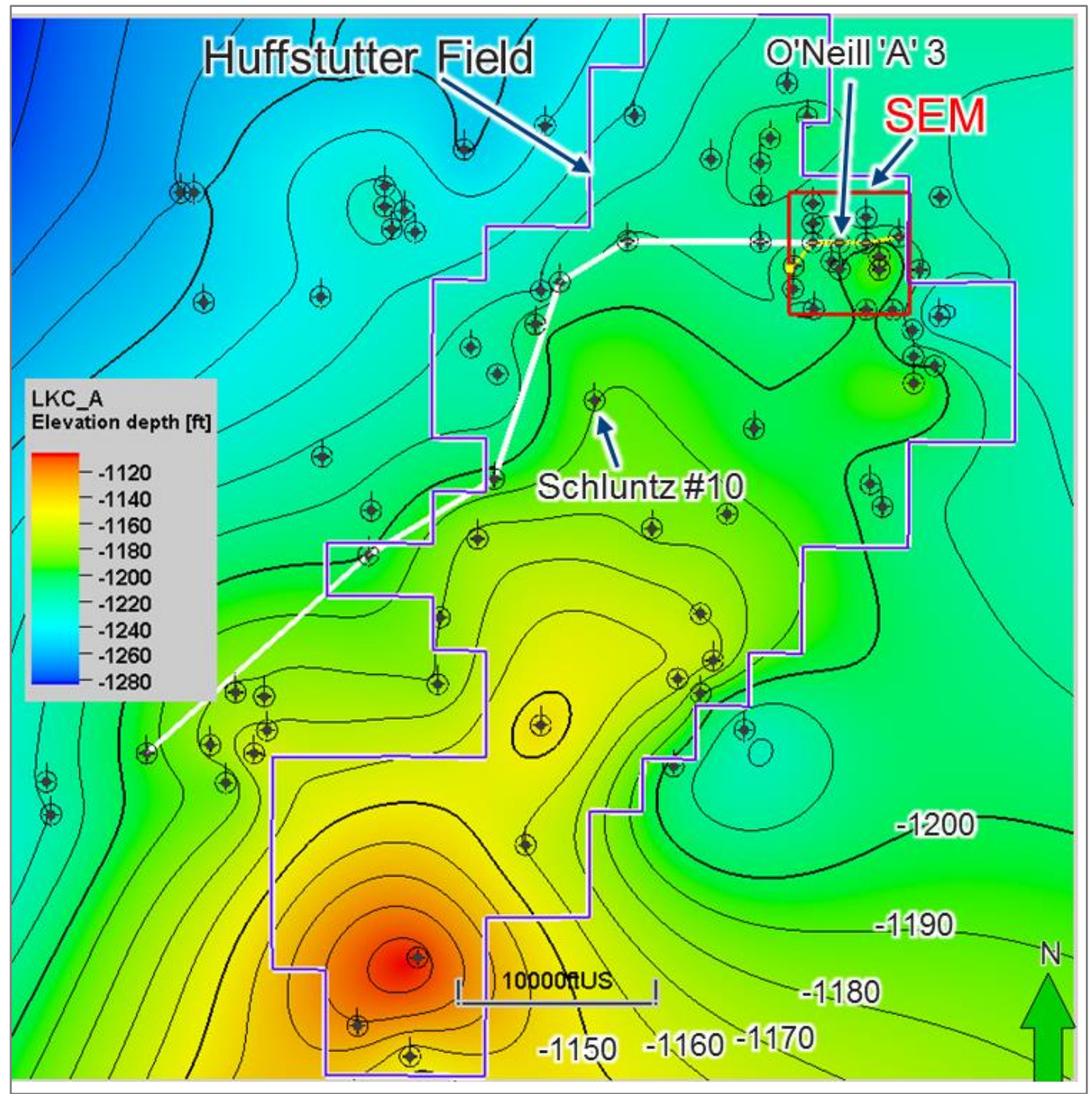

Figure 4-4. Contoured structural map for the top of the LKC at Huffstutter Field. Reference datum is mean sea level. The Contour interval is 10 feet. White line marks cross section shown in Figure 4-3. 
The focus of $\mathrm{CO}_{2}$ sequestration is on the cleaner, porous intervals in the Pennsylvanian LKC Group. Well logs and formation tops for the O'Neill 'A' 3 (API: 1514720105) (Figure 4-5) are typical of those encountered in the field. Low GR logs (XGR) are cleaner, regressive limestone zones (Figure 4-5) and represent potential $\mathrm{CO}_{2}$ storage intervals. The neutron porosity $\log (\mathrm{XNPHI})$ shows a very strong response to porosity attributed to clay-bound water within the mudstone and shale units. This interpretation is consistent with the resistivity log (XSRD) where resistivity drops over the conductive mudrock units. The potential for $\mathrm{CO}_{2}$ storage is only available in the limestone units identified by arrows in Figure 4-5. The neutron porosity log response for the clean limestones is considered reliable and indicates that available porosity is commonly less than $5 \%$. 


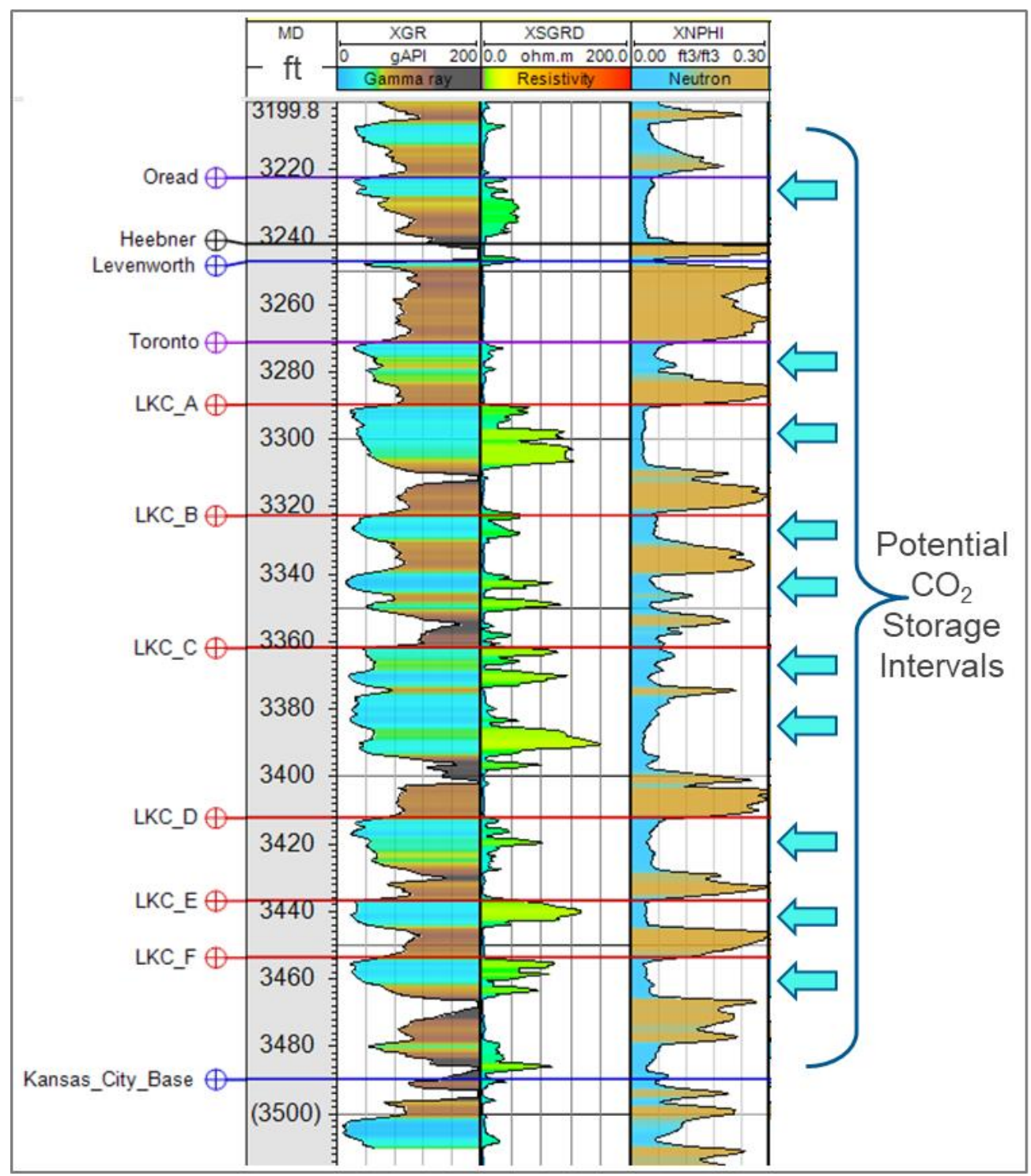

Figure 4-5. Example well logs and formation tops from the Huffstutter Field O'Neill 'A' 3 well. From left to right: GR, neutron porosity, and resistivity. The gamma ray log reveals the carbonate cycles. Potential storage intervals are in areas of low GR response and are separated by mudrocks (siliciclastic mudstones and marine shales.

\section{Static Earth Model Development (Methodology)}

The workflow for SEM development includes several steps (Figure 4-6). The workflow includes initial data compilation (step 1) and interpretation through to SEM framework (step 5) and petrophysical modeling (steps 6 and 7). The focus of this paper is on steps 2 through 10. Petrophysical modeling 
incorporates GR facies model development and property upscaling (porosity, permeability, and $\mathrm{CO}_{2}$ density) into the model grid. The model was then used to calculate storage potential.

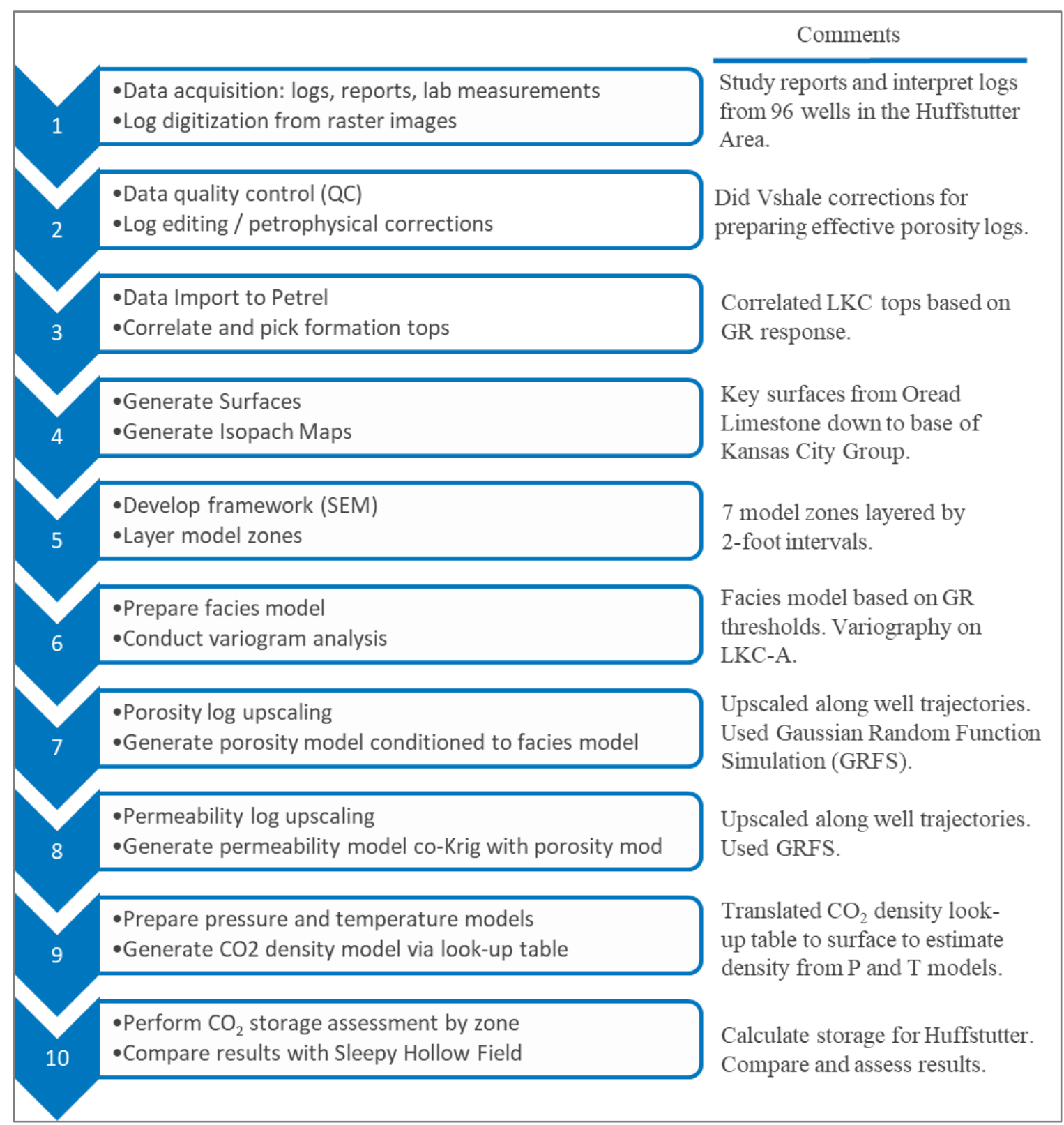

Figure 4-6. Tasks for SEM development and storage assessment.

\section{Model Surfaces}

We used well logs and tops from 96 wells in and around the Huffstutter field. In addition to the LKC formation tops, we also incorporated the overlying Oread limestone with the Heebner Shale Member into the SEM. The Heebner Shale interval is a regionally recognized unit used for well correlation. Most of the gamma ray logs used in the Huffstutter SEM started just above the Wabaunsee Group and went down 
to Pleasanton-Marmaton groups (base of the Kansas City Group). Only five wells obtained for this study have data that extends to or near the basement rock. Few wells had logs extending up through the shallower sections above the Wabaunsee Group.

The SEM framework incorporates 8 surfaces (Error! Reference source not found.a). These surfaces divide the SEM into 7 zones used for petrophysical model development (Error! Reference source not found.). The Oread cyclothem was included because it contains the Heebner Shale, a widely correlated unit in Kansas and Nebraska.

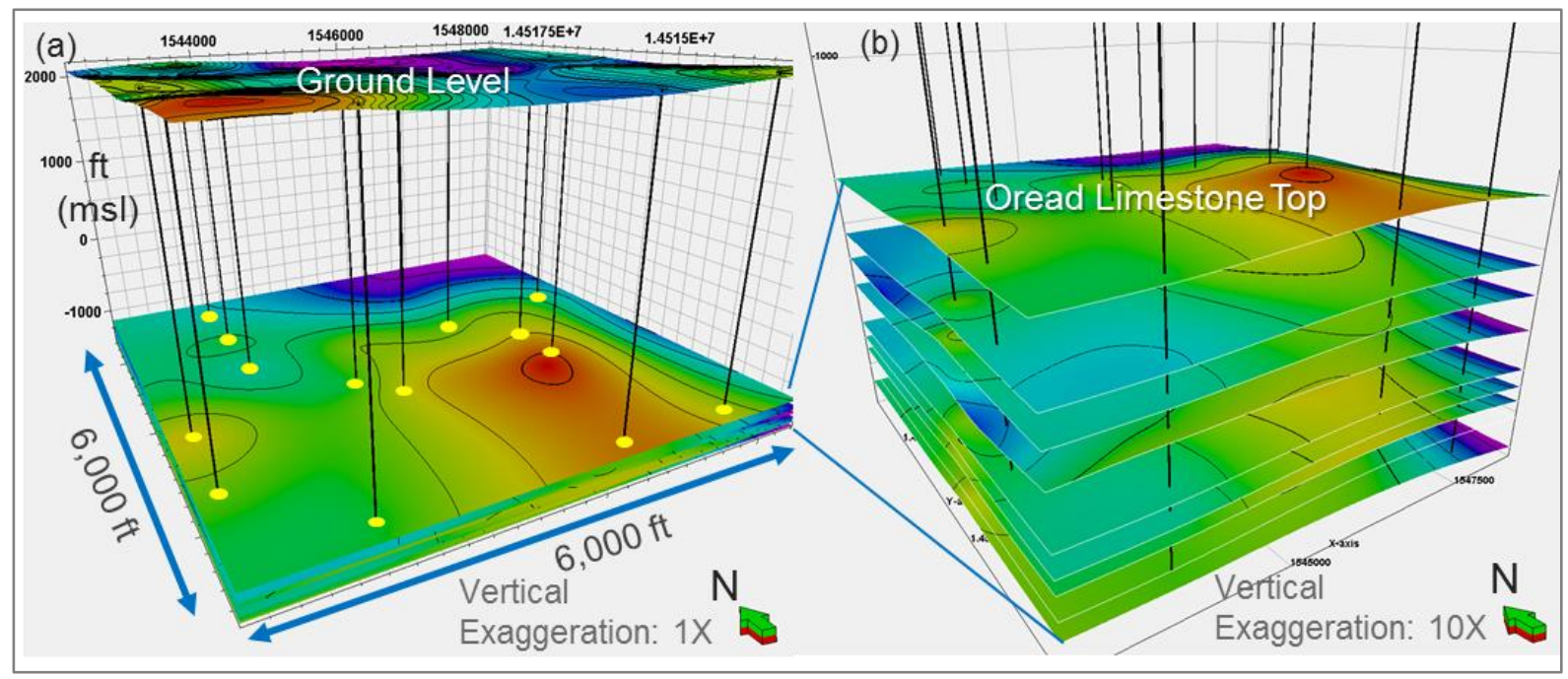

Figure 4-7. Oblique view of SEM area with wells, well tops, and surfaces. A) Well tops appear as beads along the wells. B) Close-up of the nine surfaces used to define the framework for petrophysical modeling. SEM location is shown in Figure 4-4.

The areal extent of the SEM developed in this study was limited to the $6,000 \mathrm{ft}$ by $6,000 \mathrm{ft}$ area in the northeast corner of the field where the available well data was most concentrated (as obtained for CarbonSafe, Phase I (Battelle, 2018)). The model was comprised of 2,548,800 cells. The SEM for the Huffstutter study area has a horizontal resolution defined by a grid cell XY-increment of $50 \mathrm{ft}(15.23 \mathrm{~m})$. Around 285 feet thick, the petrophysical SEM was developed for 7 zones from the Oread Member of the Douglas Group down to base of the Kansas City Group at approximately 3507 feet measured depth (MD), (Figure 4-8). The LKC portion of this SEM measures $\sim 216$ feet thick; the Oread portion is $\sim 69 \mathrm{ft}$ thick. 


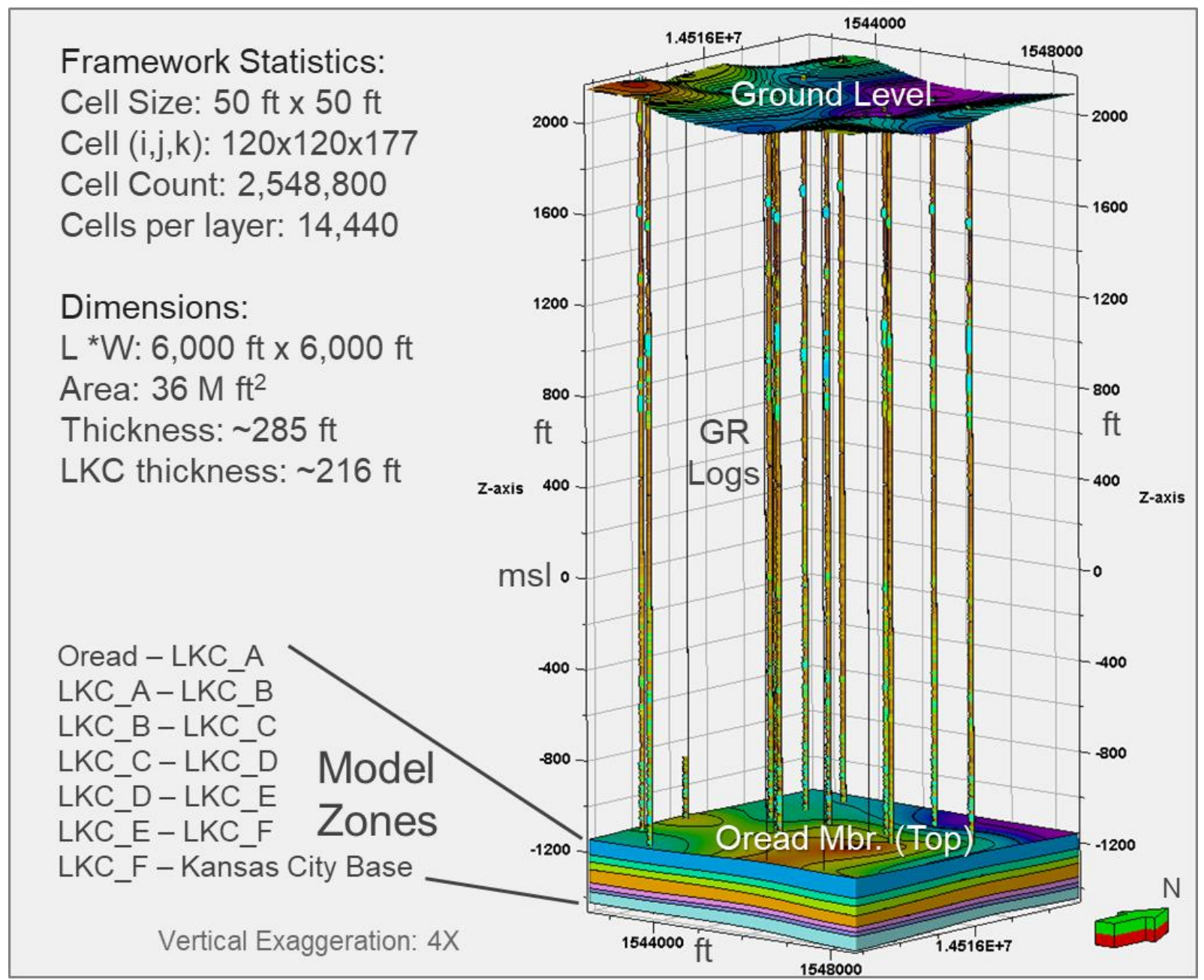

Figure 4-8. Model zones for the Huffstutter Field SEM. SEM is 6,000 ft by 6,000 ft. Petrophysical modeling was conducted for zones from the Oread Member down to the base of the Kansas City.

The surfaces define stratigraphic zones, which were subsequently layered. Each SEM zone used a 2-foot thick layering scheme. The SEM layering was sufficiently thin to capture vertical heterogeneity apparent in the permeability log. Each model layer had 120 x 120 cells for a total of 14,440 cells per layer.

\section{Facies Modeling}

Petrophysical modeling is commonly preceded by facies modeling. Facies models enable better control over how the petrophysical properties get distributed. While facies models can vary in complexity, the goal here was to define the different "flow units," essentially delineating reservoir rock from non-reservoir rock. GR logs were used here as the basis for a GR facies model and is described below. 
The GR facies model was prepared in three steps: 1) using the arithmetic mean sampling method (Figure 4-9), the gamma ray logs were upscaled into the 3D geocellular grid along their well trajectories. This occurs at 2-foot $(0.61 \mathrm{~m})$ intervals corresponding to the grid's layering. 2) These GR data were then interpolated into the 3D grid area, between wells, using the moving average method with a point weighting of inverse distance squared. This approach quickly populates the 3D grid and can only generate values no smaller or larger than the minimum and maximum values of the input data, respectively. The moving average interpolation technique finds an average of the input data and weighs according to the distance from the wells. The horizontal setting was isotropic, and the vertical range was set to 2 feet $(0.61 \mathrm{~m})$. Figure 4-10 shows a cross-section and 3D view of the GR facies model and how it correlates among the wells. The moving average method was selected because GR signatures were highly correlated and could usually be traced across the entire oilfield, like those shown in Figure 4-3. Furthermore, the moving average method was used here as a coarse delineation of facies (described next); Gaussian Random Function Simulation (GRFS) is used later during petrophysical modeling to introduce heterogeneity. 3) The GR model was then translated into a discrete facies model using the following gamma ray thresholds and assigned codes $(0,1$, and 2):

(0) GR < 70: Carbonate-dominated; oolitic, packstone, peloidal, and skeletal grainstones are of particular interest as reservoir rocks (Dunham classification). This also includes other carbonate rock types, including lime-mudstones and wackestones.

(1) $70<$ GR < 120: Mudstone-dominated, includes illite-rich, reddish siliciclastic mudstones, with pedogenetic features.

(2) GR > 120: Shale-dominated, commonly black or dark gray marine shale.

This GR facies model followed the approach used by Smith et al. (in press) and described in Chapter 3. A cross-section through the cyclic carbonate GR facies model is given in Error! Reference source not found.a. An oblique view of the facies model is shown in Figure 4-10b. The upper surface is the top of the Oread Member. 


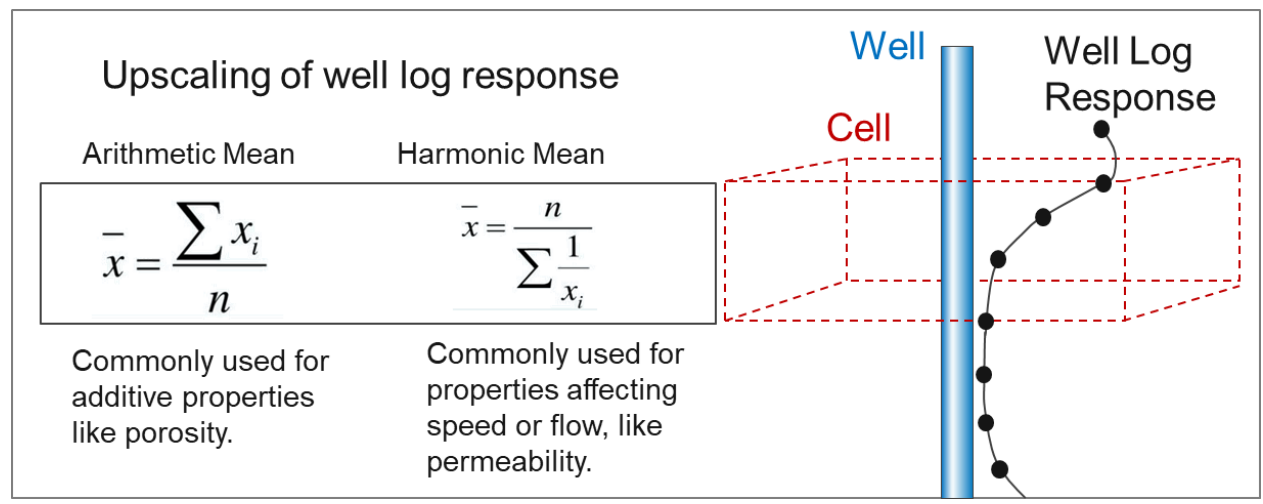

Figure 4-9. Methods for well log upscaling into SEM grid cells along vertical well trajectory. 


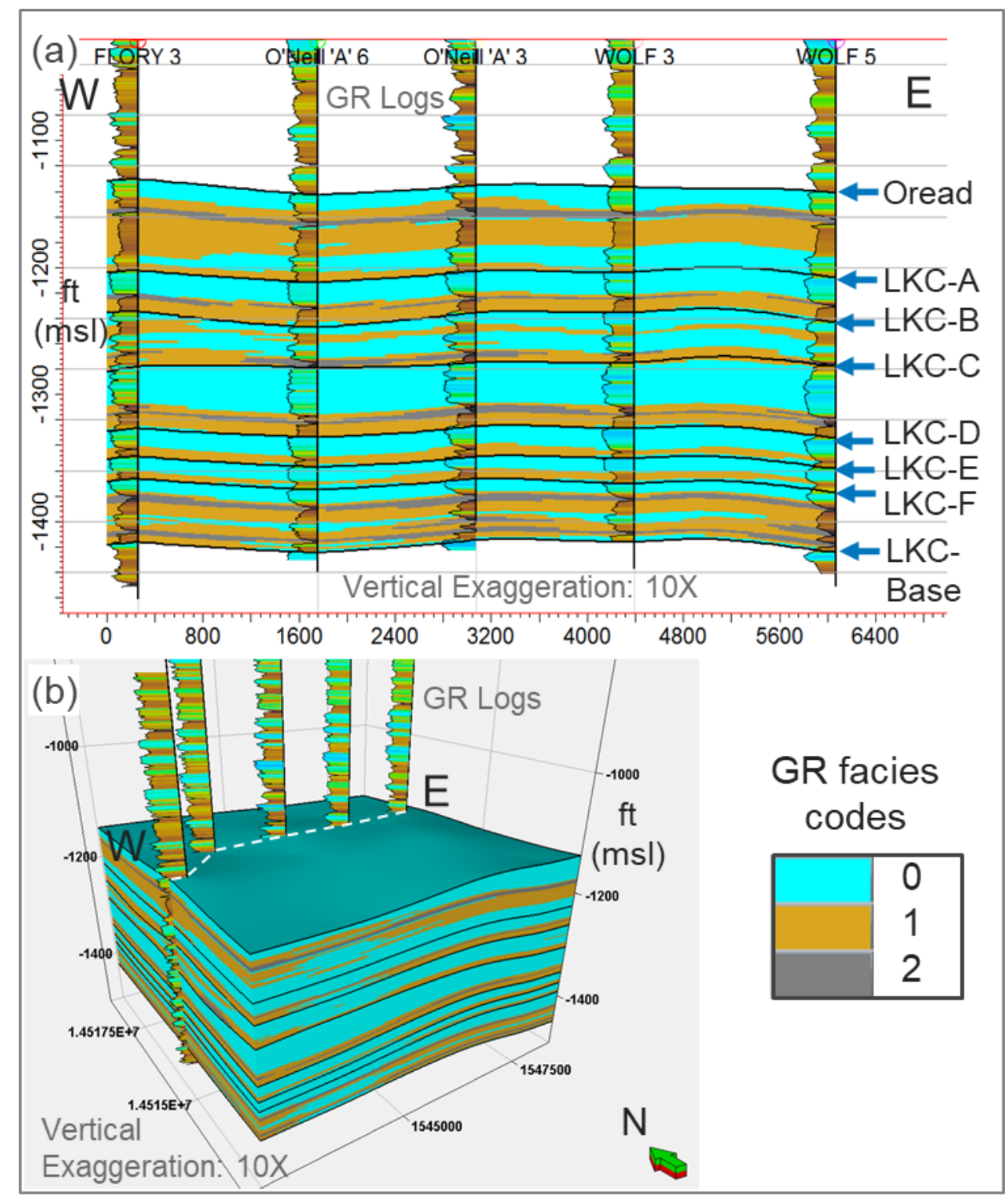

Figure 4-10. GR facies model for the Huffstutter study area. (a) Well section of GR facies model through the SEM representing the LKC. (b) Oblique view of GR facies model showing the top of the Oread Limestone. Wells correspond to those shown in (a). 


\section{Petrophysical Properties}

Neutron porosity logs served as the key input for deriving effective porosity logs. As noted above, mudrock units have a large porosity response, and this was taken to represent ineffective porosity. Thus, a GR "shale volume correction" was applied to the NPHI logs for a better representation of effective porosity. The $\mathrm{V}_{\text {shale }}$ correction method (Asquith, 2006) was used per equations 4-1 and 4-2.

$\mathrm{V}_{\text {shale }}=\left(\mathrm{GR}_{\log }-\mathrm{GR}_{\text {res }}\right) /\left(\mathrm{GR}_{\text {shale }}-\mathrm{GR}_{\text {res }}\right)$

Where:

$\mathrm{V}_{\text {shale }}=$ shale fraction (i.e. non-reservoir)

$\mathrm{GR}_{\log }=$ gamma ray log value

$\mathrm{GR}_{\text {res }}=$ gamma ray value of clean (i.e., low clay) carbonate rock in each zone

$\mathrm{GR}_{\text {shale }}=$ gamma ray value from a nearby shale interval

PHIe $=$ PHI $_{t} *\left(1-\mathrm{V}_{\text {shale }}\right)$

Where:

$\mathrm{PHI}_{\mathrm{e}}=$ effective porosity

$\mathrm{PHI}_{\mathrm{t}}=$ total porosity (uncorrected, commonly a NPHI log)

$1-\mathrm{V}_{\text {shale }}=$ sandstone and/or carbonate fraction (i.e. reservoir fraction)

Despite this correction, many of the mudrock intervals showed effective porosity comparable and sometimes greater than the adjacent carbonate reservoir intervals. Fundamentally, the mudrocks (caprocks) should have less effective porosity than the carbonates. Thus, further correction or attenuation of PHIe logs for the mudrock intervals was necessary and was multiplied by a scaling factor in equation 4-3; this scaling factor is plotted in Figure 4-11.

PHIE70 $=$ If $\left(\mathrm{GR}_{\log }>70\right.$, then PHIe * $\left(150-\mathrm{GR}_{\log }\right) / 150$, else PHIe $) \quad$ [Eq. $\left.4-3\right]$

Where:

$\mathrm{PHI}_{\mathrm{e}}=$ effective porosity from initial Vsh correction (Eq. 4-2).

$\mathrm{GR}_{\log }=$ gamma ray log value

PHIE70 = effective porosity with further porosity attenuation for mudrock where $\mathrm{GR}_{\log }>70$.

An example of an original NPHI log $\left(\mathrm{PHI}_{\mathrm{t}}\right)$ and corrected effective porosity log (PHIe) is shown in tracks 3 and 4 for well O'Neal 'A' 3 (UWI 1514720654) (Figure 4-13); the final corrected PHIE70 log is given in track 5 with it upscaled counterpart in track 6. 
Permeability logs were based on a porosity-permeability transform (equation 4-4) derived from LKC core samples taken from the Sleepy Hollow Field (Figure 4-12), Battelle (2018). Like the initial effective porosity logs, these were also found to be high for the mudrock intervals, and an attenuation factor was applied per equation 4-5. The initial permeability log and its final upscaled counterpart are shown in track 7 (Figure 4-13).

$\mathrm{PERM}=180.73 * \mathrm{PHI}_{\mathrm{e}}{ }^{1.91}$

Where:

[Eq. 4-4]

$\mathrm{PHI}_{\mathrm{e}}=$ effective porosity from initial Vsh correction (Eq. 4-2).

PERM70 = If $\left(\mathrm{GR}_{\log }>70\right.$, then PERM * $((150-\mathrm{GR} \log ) / 150)^{2}$, else PERM $) \quad$ [Eq. 4-5]

Where:

PERM = permeability log from (Eq. 4-3).

$\mathrm{GR}_{\log }=$ gamma ray log value

PERM70 = permeability log with further attenuation for mudrock where $\mathrm{GR}_{\log }>70$.

In summary, favorable porosity and permeability are associated with cleaner carbonate units where porosity development occurs (Young, 2011). Effective porosity and permeability logs and their upscaled counterparts have been attenuated for the mudstone and shale units, (Figure 4-13) tracks 6 and 7, where the GR facies code $=1$ or 2 . Effective porosity and permeability logs were kept unchanged for carbonate intervals, GR facies code 0 . 


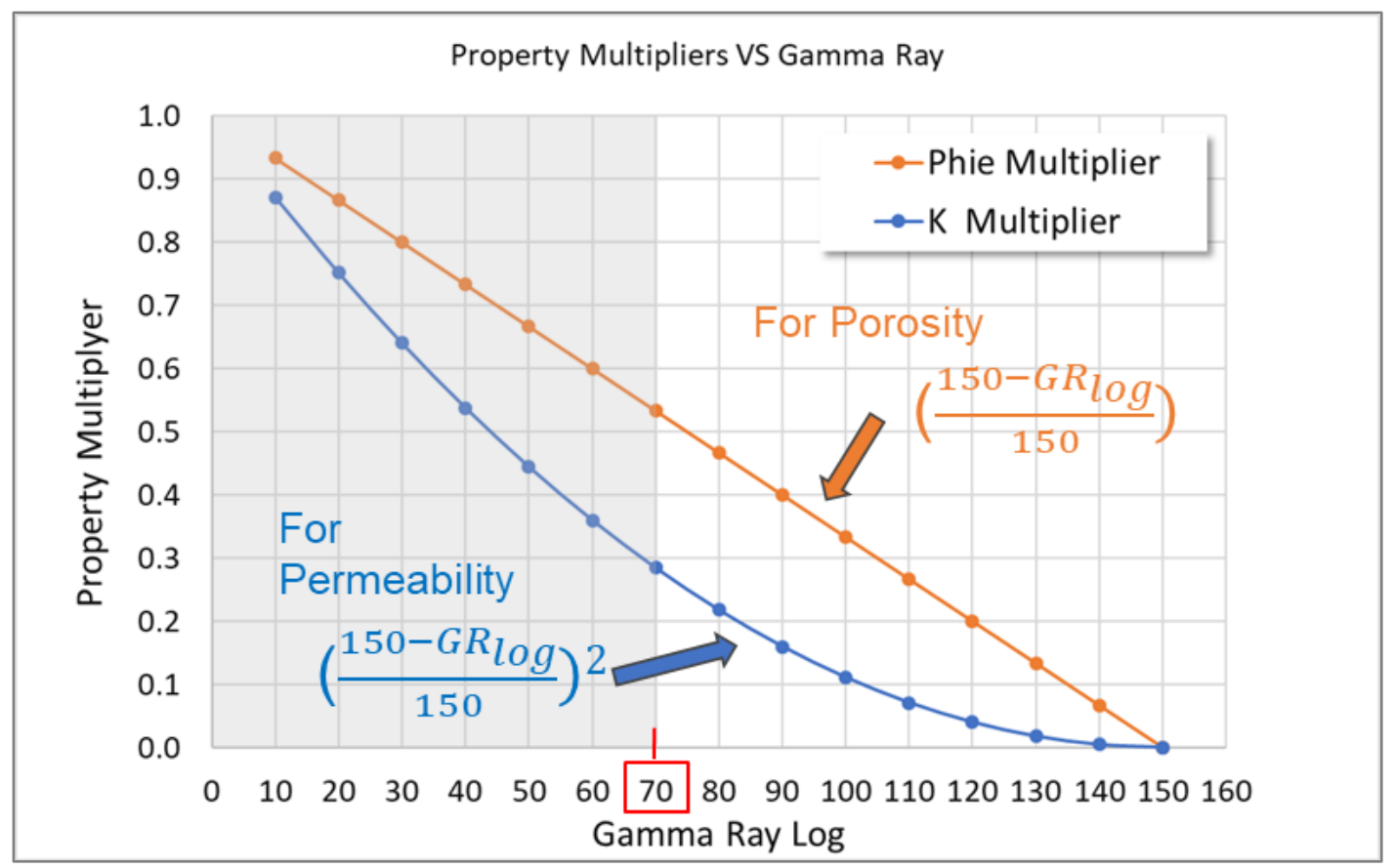

Figure 4-11. Cross-plots of multipliers used to re-scale effective porosity logs (equation 4-3) and permeability logs (equation 4-4) for mudrock intervals where $G R_{\log }>70$.

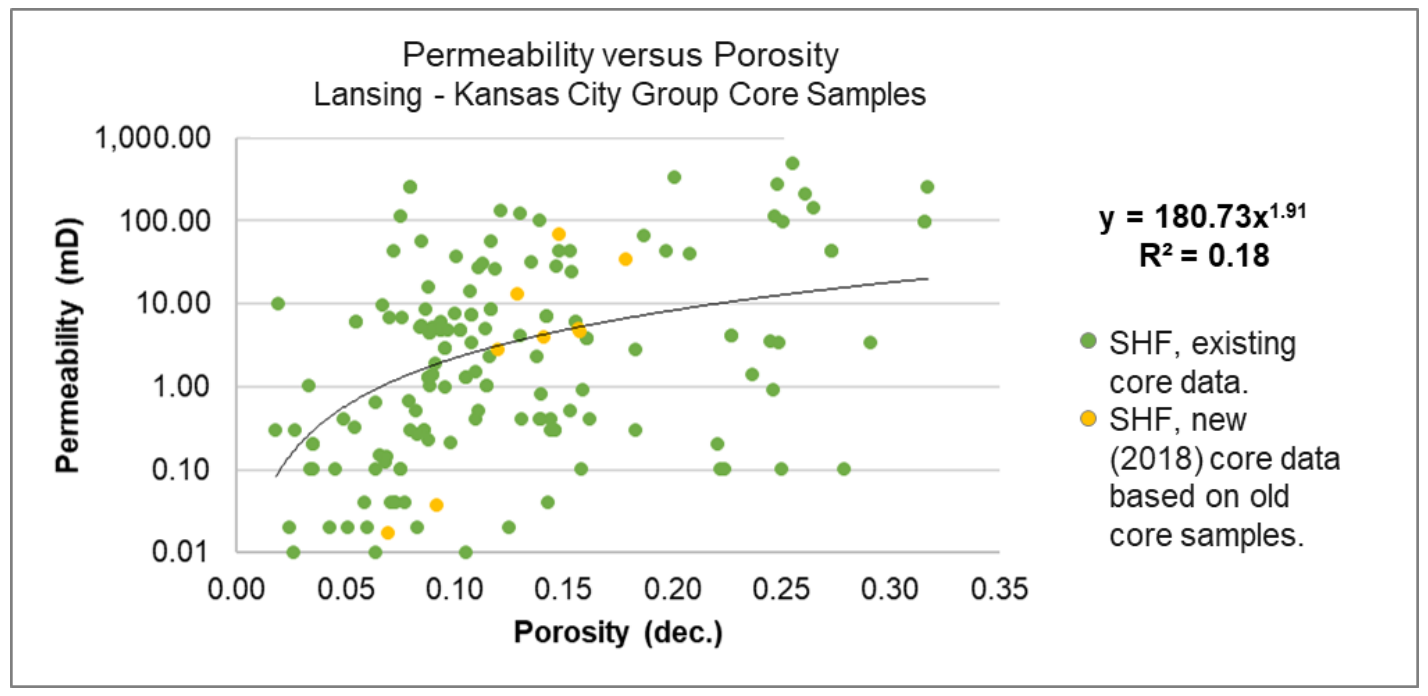

Figure 4-12. Permeability-porosity cross-plot for Sleepy Hollow Field core samples. This regression was used to predict a permeability log from porosity logs (PHIe). 


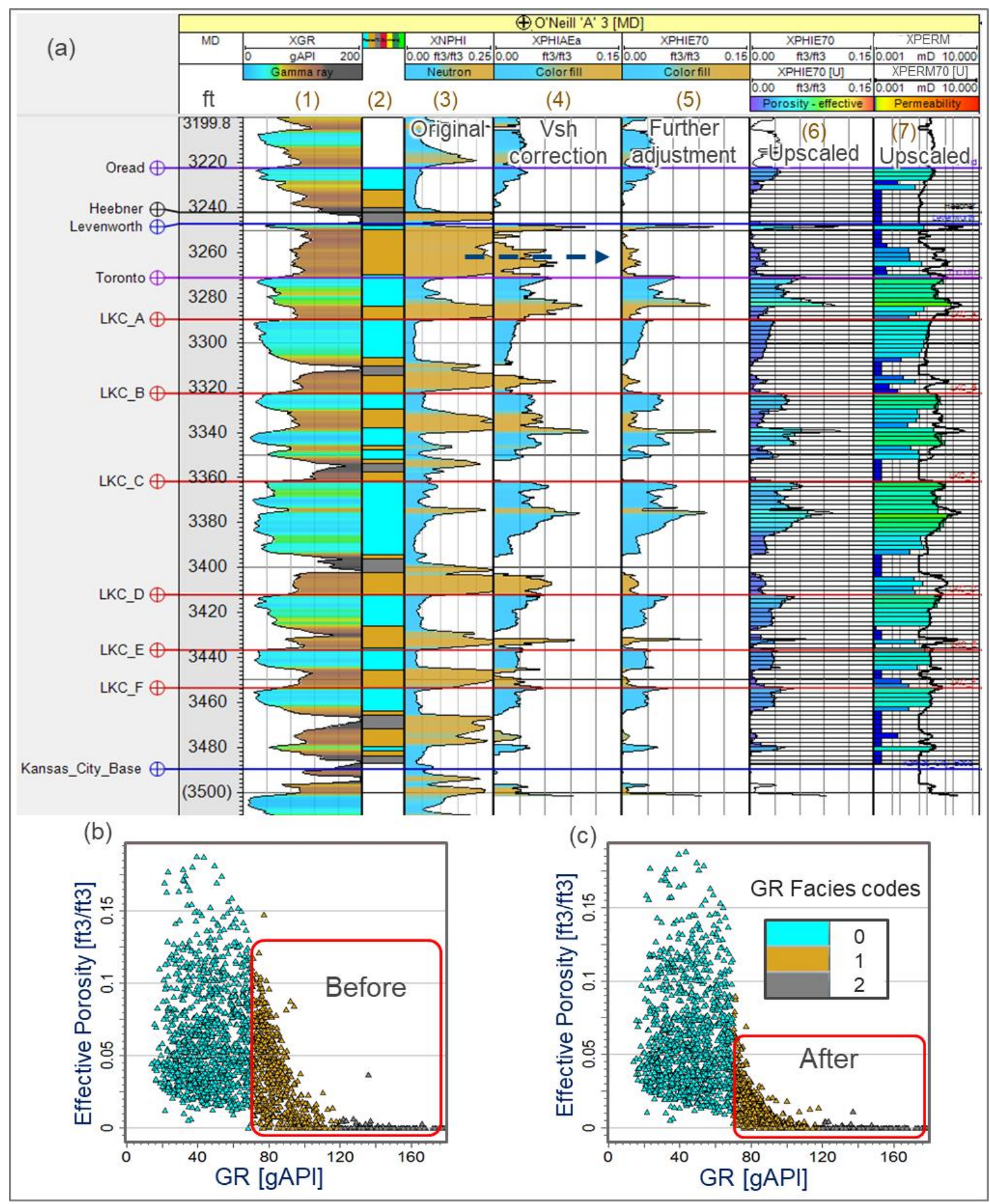

Figure 4-13. Example porosity and permeability log adjustments for the Huffstutter SEM. A) Original neutron porosity, log track (3), effective porosity V-shale corrected (4), and porosity further attenuated for mudrocks (5), upscaled effective porosity (6), and upscaled permeability (7). (b) Effective porosity partitioned by GR facies after V-shale correction. (c) Same data set with further attenuation to effective porosity logs representing mudrocks and shales; thus, red boxes encompass the same population of data points. 


\section{Effective Porosity Modeling}

The arithmetic mean upscaling method (Figure 4-9) was used to sample the corrected effective porosity logs (PHIE70) at a 2-foot resolution corresponding to the thickness of the 3D grid cells along their well trajectories. Effective porosity interpolation into inter-well grid cells used a Gaussian Random Function Simulation (GRFS) while being conditioned by the GR facies model. Essentially, the effective porosity is being distributed vertically and laterally in a way that is consistent with the GR facies trends observed from the wells. The resulting effective porosity model (Figure 4-14) highlights effective porosity variations within the carbonate zones. A cross-section through the SEM (Figure 4-14a) reveals the alternating carbonate and mudrock units. An oblique view of the SEM's LKC section (Figure 4-14b) illustrates variations in effective porosity across the top of the model. The effective porosity histogram (Figure 4-14c) reveals the similarity between the effective porosity from log input, the upscaled (sampled) $\operatorname{logs}$, and the resulting property model. These histograms are limited to the LKC zones, and their values are representative over the domain they occupy: the well logs at $1 / 2$-foot intervals, the upscaled values at 2 -foot intervals, and the final property model over its entire 3D volume. 


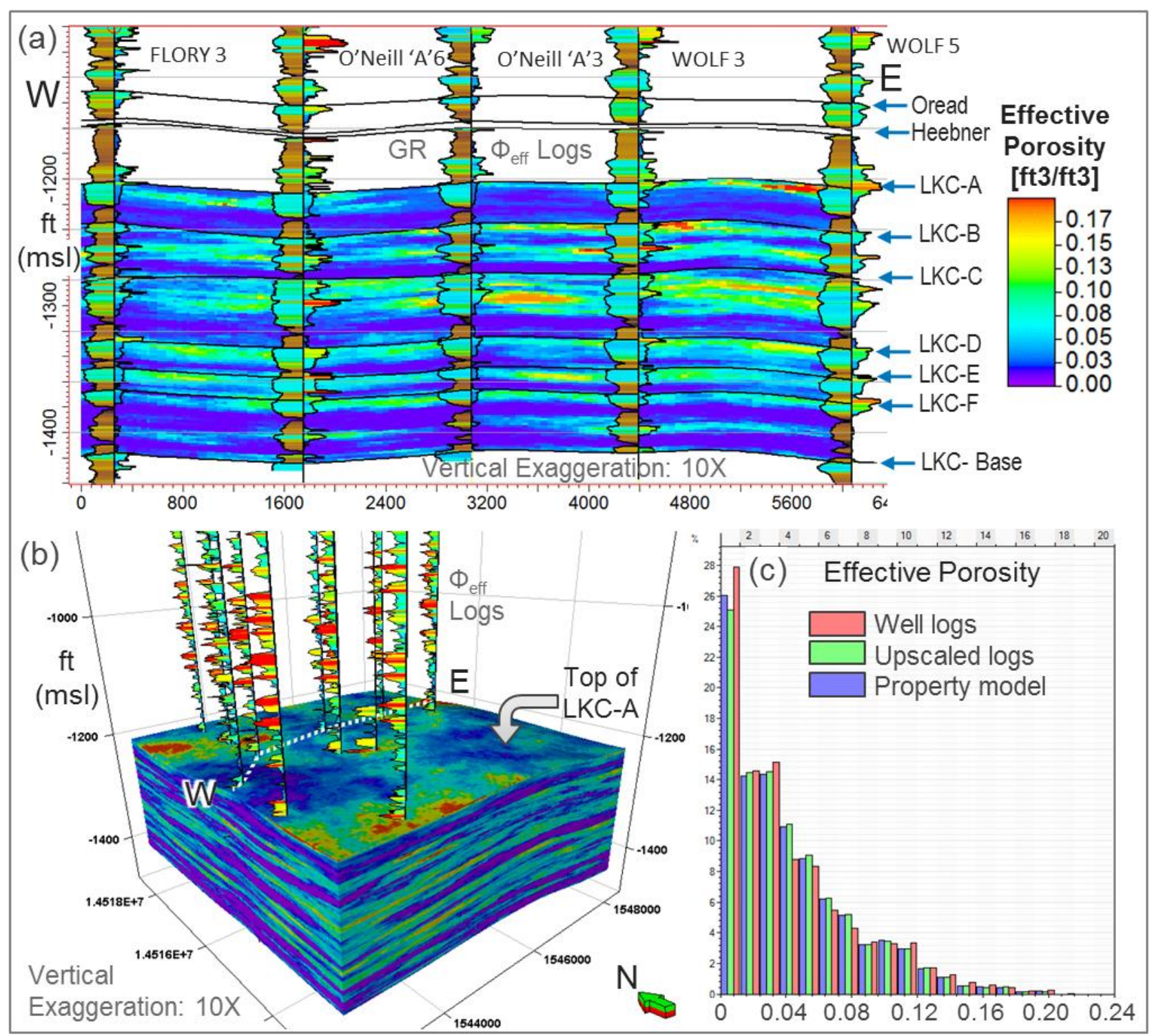

Figure 4-14. Effective porosity model (a) Cross-section through the effective property model. (b) Oblique view of effective porosity model along with effective porosity logs. (c) Effective porosity histograms for well logs, upscaled well logs, and the final 3D effective porosity model. 


\section{Permeability Modeling}

For permeability modeling, the permeability logs were derived from a porosity power-law regression between core porosity and core permeability from Sleepy Hollow Field (Figure 4-12). This transform was then used to compute permeability logs from the effective porosity logs, as described earlier. The permeability logs were upscaled into the model grid along vertical well trajectories using a harmonic mean method (Figure 4-9). The permeability model was then interpolated through the entire 3D model grid using GRFS and collocation co-kriged with the effective porosity model. Figure 4-15 shows a cross-section of the resulting permeability model, an oblique view of the $3 \mathrm{D}$ grid, and corresponding permeability histograms. Because the permeability model was generated through collocated, co-kriging with the porosity model, it has a similar spatial distribution with the porosity model. Tighter intervals appear as purple streaks in the cross-section and are related to regressive mudrocks or transgressive marine shale (Figure 4-15). As modeled, the more permeable intervals correspond to the regressive carbonates. Still, the permeability offered by the carbonate rock here is small and commonly less than $10 \mathrm{mD}$. 


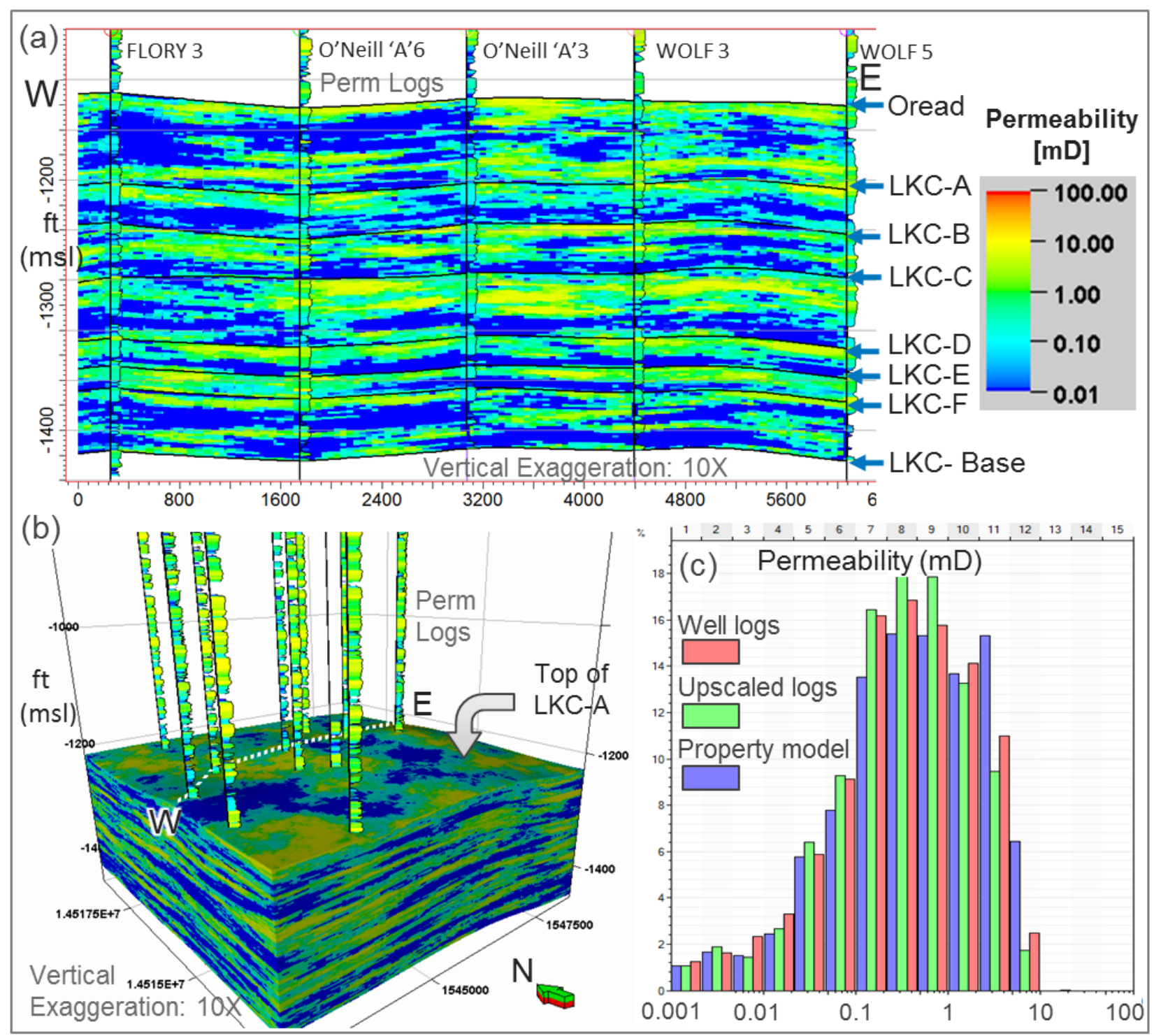

Figure 4-15. Permeability model (a) Cross-section through the permeability model. (b) Oblique view of permeability model. (c) Permeability histograms for well logs, upscaled well logs, and the final 3D permeability model. 


\section{Pressure, Temperature, and $\mathrm{CO}_{2}$ Density Modeling}

In order to estimate potential $\mathrm{CO}_{2}$ storage capacity, $\mathrm{CO}_{2}$ density is required and is dependent on reservoir pressure and temperature. Both pressure and temperature are dependent on depth. Drill stem testing (DST) acquired June 2019 at the Sleepy Hollow Field was used as the basis for predicting reservoir pressure and temperature as a function of depth. This data is considered a good proxy for Huffstutter Field due to the correlation of Pennsylvanian stratigraphic units and similar depths. The DST was conducted at three depths, and the resulting data were plotted to determine functions for representing the pressure gradient and the temperature gradient. Cross-plots for pressure and temperature gradients are shown in Figure 4-16a and Figure 4-16b, respectively. A linear regression model was used to predict reservoir pressure as a function of depth (Figure 4-16a). A linear regression model was also used to predict reservoir temperature as a function of depth (Figure 4-16b). The regression models were used to assign values of temperature and pressure to all cells in the SEM. As $\mathrm{CO}_{2}$ density cannot be fully described by a single equation, a look-up table is commonly used. Cell-by-cell, the SEM's pressure and temperature values were used to determine $\mathrm{CO}_{2}$ density through a look-up table from NETLCO2-SCREEN (Goodman et al., 2016). A 3D representation of the look-up table is provided as a contoured surface (Figure 4-16c) along with a histogram of the $\mathrm{CO}_{2}$ densities from the corresponding LKC model region. As modeled, the reservoir conditions for the LKC at Huffstutter Field are summarized below.

Temperature: $94.8^{\circ} \mathrm{F}$ to $98.2^{\circ} \mathrm{F}\left(34.8^{\circ} \mathrm{C}\right.$ to $\left.36.8^{\circ} \mathrm{C}\right)$

Pressure: 1599 psi to $1779 \mathrm{psi}(11.02 \mathrm{MPa}$ to $12.26 \mathrm{MPa})$

Density: $735 \mathrm{~kg} / \mathrm{m}^{3}$ to $754 \mathrm{~kg} / \mathrm{m}^{3}\left(45.88 \mathrm{Lbs} / \mathrm{ft}^{3}\right.$ to $\left.47.07 \mathrm{Lbs} / \mathrm{ft}^{3}\right)$ 


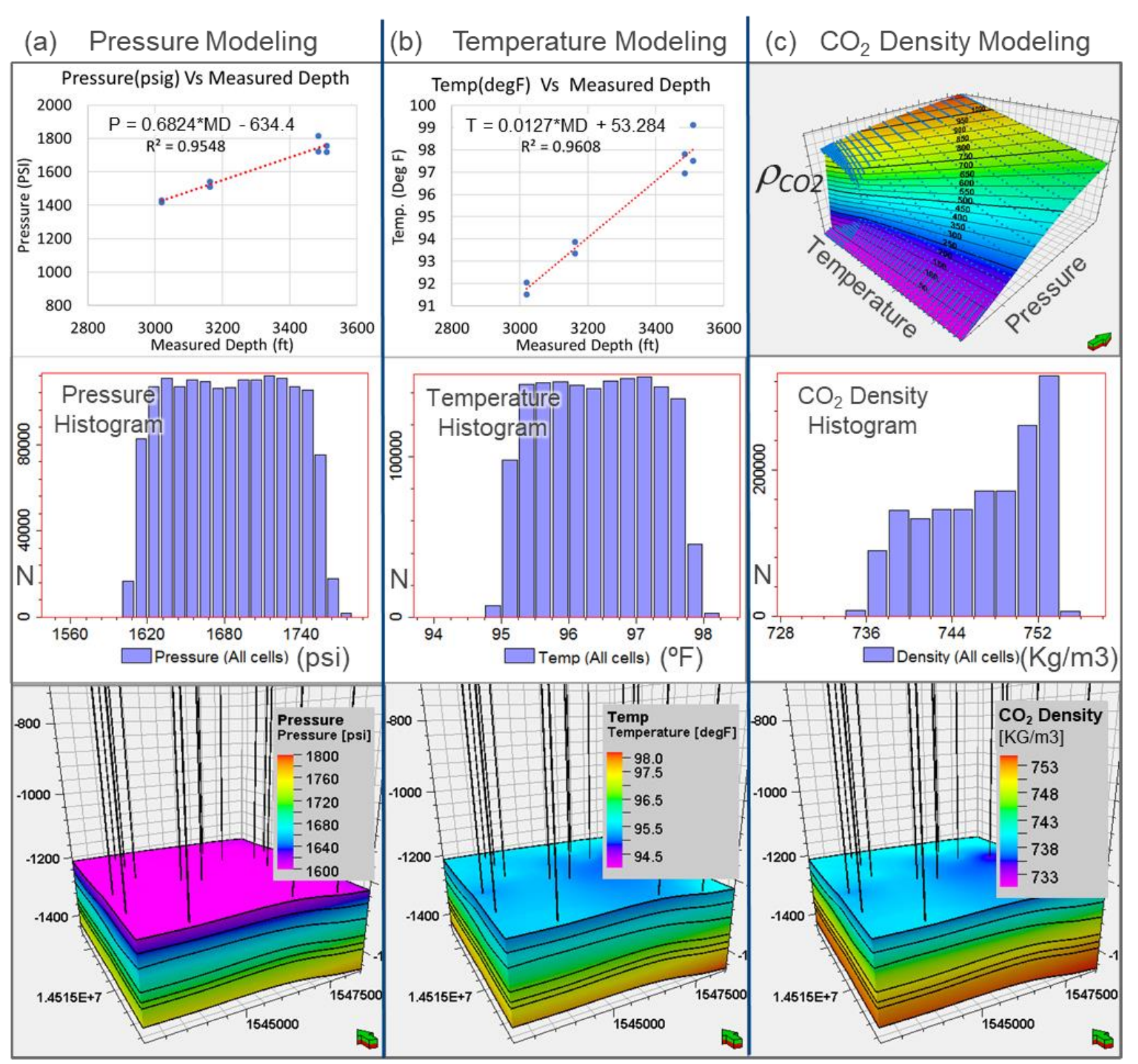

Figure 4-16. Pressure, temperature, and density models prepared for the Huffstutter SEM based on DST results from Sleepy Hollow Field. (a) From top to bottom: pressure gradient function, modeled ranges of pressure for the LKC at Huffstutter Field, 3D pressure gradient model. (b) temperature gradient function, modeled range of temperatures for the LKC at Huffstutter Field, 3D temperature gradient model. (c) $\mathrm{CO}_{2}$ density look-up surface, modeled range of $\mathrm{CO}_{2}$ density for the $\mathrm{LKC}$ at Huffstutter Field, $3 \mathrm{D} \mathrm{CO}_{2}$ density model. 


\section{Storage Assessment}

The $\mathrm{CO}_{2}$ storage resource estimate for the LKC was computed using Equation 4-6 and the 3D SEM which included models for the bulk volume $(V c)$, effective porosity $\left(\phi_{\mathrm{e}}\right)$, Pressure $(\mathrm{P})$, Temperature $(\mathrm{T})$, $\mathrm{CO}_{2}$ Density $\left(\rho_{\mathrm{CO} 2}(\mathrm{P}, \mathrm{T})\right)$, and a storage efficiency factor of 0.1 . Equation $4-6$ is applied to the $3 \mathrm{D}$ geocellular model such that estimates of $\mathrm{CO}_{2}$ storage mass is computed directly on individual cells and added together to produce the total $\mathrm{CO}_{2}$ storage mass estimate for 1 square mile of $\mathrm{LKC}$.

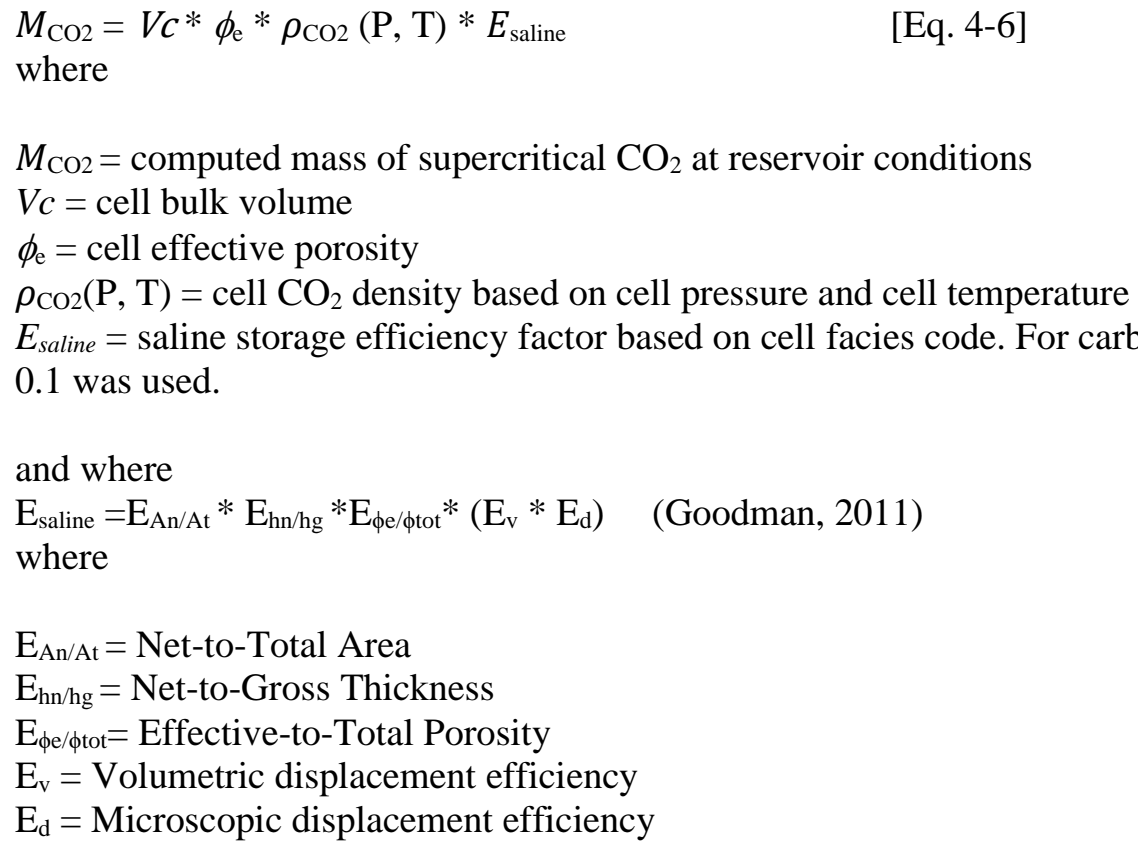

With the cell volumes, effective porosity, area, and thickness of the reservoir rock well defined by the model

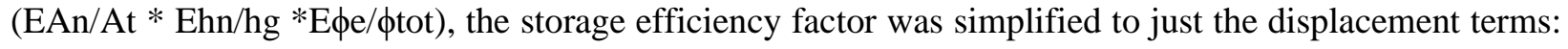
$E_{\text {saline }}=\left(\mathrm{E}_{\mathrm{v}} * \mathrm{E}_{\mathrm{d}}\right)$ where $\mathrm{E}_{\mathrm{v}}$ is the volumetric displacement efficiency factor, and $\mathrm{E}_{\mathrm{d}}$, the microscopic displacement efficiency factor. $E_{\text {saline }}=0.1$ was used and represented the p10 level for limestone per Peck et al. (2014). Based on 1 square mile of LKC section at Huffstutter Field, the computed $M_{\mathrm{CO} 2}$ results are provided in Table 4-1. The calculation assumed that all carbonate units were accessible for $\mathrm{CO}_{2}$ injection. For the purpose of comparing carbon storage between Huffstutter and Sleepy Hollow Fields, the carbonate units were assumed to be saline because oil-bearing units can vary by field. Furthermore, these are mature oilfields that are slowly being depleted (increasingly saline), and the determination of water saturation over produced intervals would require still more assumptions. Finally, the presence of oil is the exception rather 
than the rule, and for many $\mathrm{CO}_{2}$ point sources (like regional corn ethanol plants in Nebraska), their onsite geologic $\mathrm{CO}_{2}$ storage considerations will likely require the saline units of the $\mathrm{LKC}$ as one of their storage options.

Under these assumptions and conditions, the $\mathrm{CO}_{2}$ would occupy the carbonate units and would appear to be partitioned by the mudrock units (Figure 4-17). Back calculations show that for an LKC carbonate lithology with facies code 0 , the typical SEM cell $(50 \mathrm{ft}$ x $50 \mathrm{ft}$ x $2 \mathrm{ft})$ or $(15.4 \mathrm{~m}$ x $15.4 \mathrm{~m} 0.61$ $\mathrm{m})$ holds an average of $591 \mathrm{~kg}$ of $\mathrm{CO}_{2}$ with an average effective porosity of $5.83 \%$.

Table 4-1. Carbon storage resource estimated by zone for the LKC carbonate reservoir units, GR facies code 0.

\begin{tabular}{cccc}
\hline LKC unit & $\begin{array}{c}\text { Effective } \\
\text { reservoir }(\%)\end{array}$ & $\begin{array}{c}\text { Tonnes } \\
\mathrm{CO}_{2} / \mathrm{mile}^{2}\end{array}$ & $\begin{array}{c}\text { Tonnes } \\
\mathrm{CO}_{2} / \mathrm{km}^{2}\end{array}$ \\
\hline LKC zone A & 58 & 53,427 & 20,628 \\
LKC zone B & 66 & 92,092 & 35,557 \\
LKC zone C & 65 & 125,343 & 48,395 \\
LKC zone D & 71 & 61,815 & 23,867 \\
LKC zone E & 73 & 55,555 & 21,450 \\
LKC zone F & 36 & 55,123 & 21,283 \\
\hline Total: & & 443,355 & 171,180 \\
\hline
\end{tabular}

* Percent of zonal volume comprised of carbonate reservoir rock; the remaining zonal portion is either mudrock or shale. 


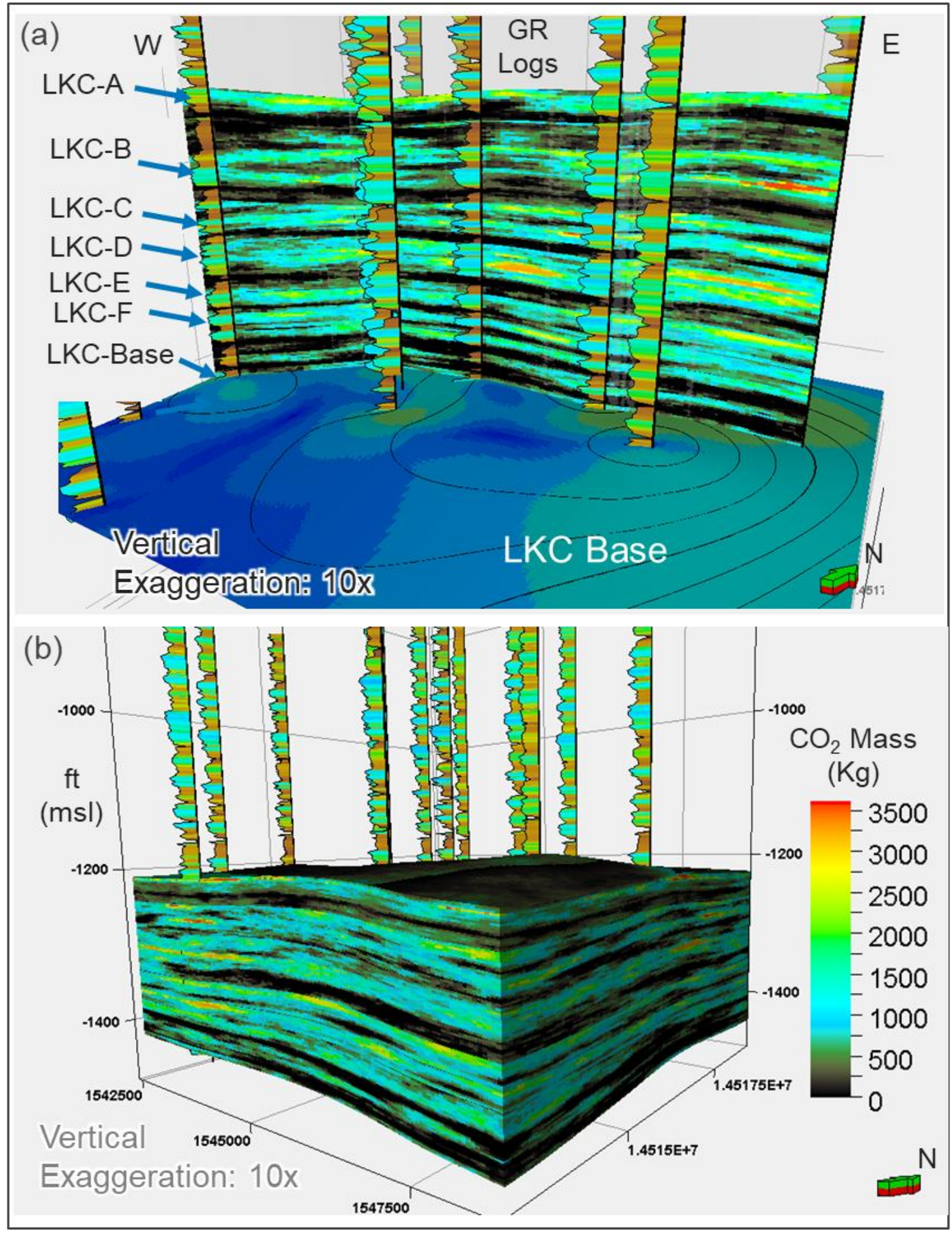

Figure 4-17. Computed $\mathrm{CO}_{2}$ mass storage results, by cell, for the LKC. Light areas represent computed $\mathrm{CO}_{2}$ storage based on $\mathrm{CO}_{2}$ density and reservoir pore space accessibility. (a) Vertical slice through the SEM showing $\mathrm{CO}_{2}$ mass; the dark areas represent mudrock intervals. (b) Oblique view of SEM with computed $\mathrm{CO}_{2}$ mass storage, by cell. 


\section{Contrast and Comparison between Huffstutter and Sleepy Hollow Field}

For both Sleepy Hollow Field and Huffstutter Field, computed $\mathrm{CO}_{2}$ storage estimates were based on an area of 1 square mile, and the storage efficiency was set at $E_{\text {saline }}=0.1$. With these parameters fixed, the differences in $\mathrm{CO}_{2}$ storage depends on overall reservoir thickness, effective porosity, and $\mathrm{CO}_{2}$ density. The density of the $\mathrm{CO}_{2}$ will depend on pressure and temperature as a function of depth. A comparison of the depth and thickness of the LKC in these two fields are shown in Figure 4-18. Separated by approximately 55 miles, the stratigraphic depth and thickness for these two fields are remarkably similar. From the SEM's, the top of the LKC at Huffstutter is only 140 feet (43 m) deeper than at Sleepy Hollow Field.

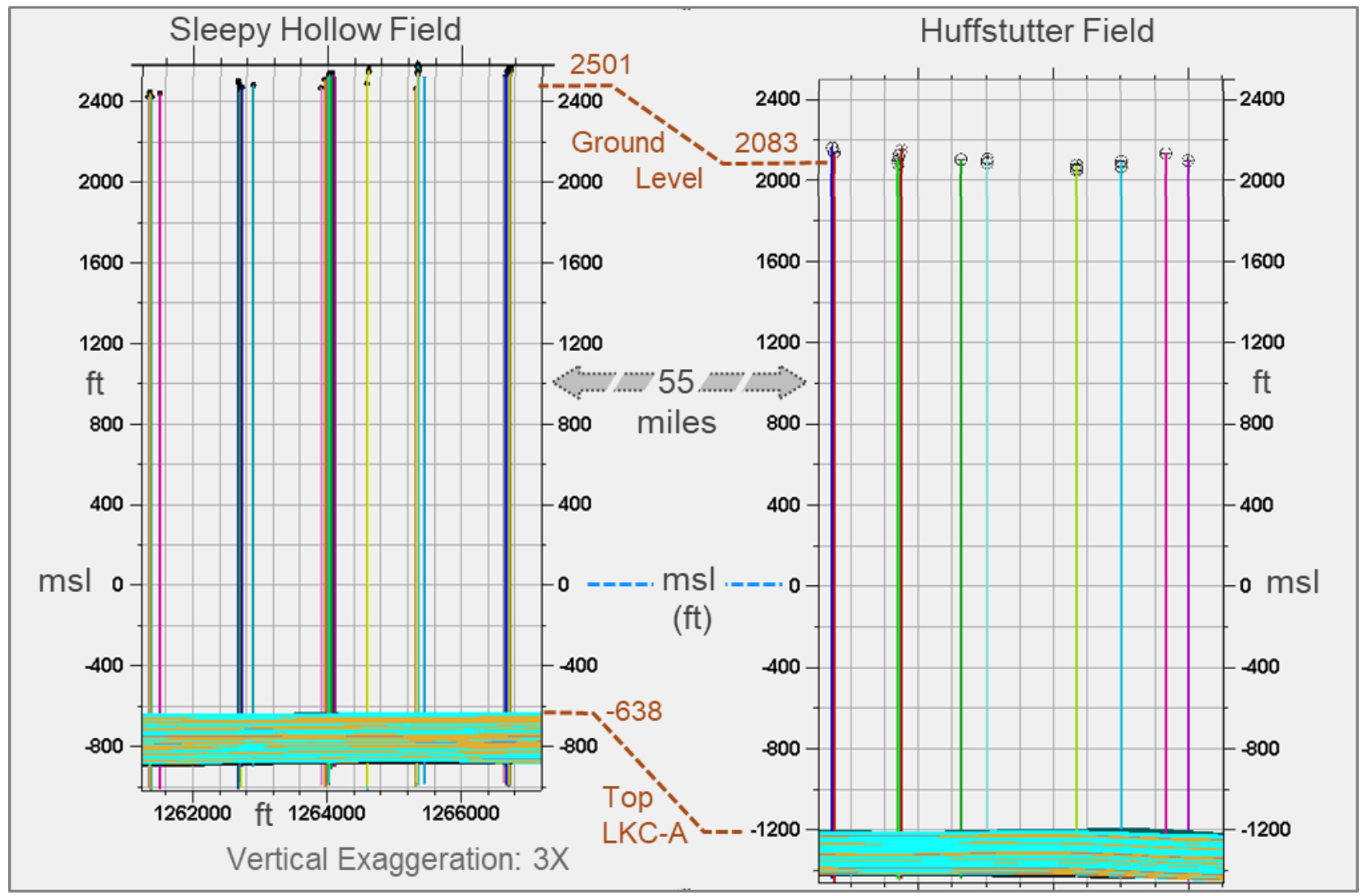

Figure 4-18. The relative depth and thickness of LKC SEMs for Sleepy Hollow and Huffstutter Fields are shown side by side. The view is from the south and shows well trajectories penetrating the LKC facies models. 
Based on the SEMs prepared for the LKC, the computed mean LKC thickness (LKC-A through LKC Base) at Sleepy Hollow was $250 \mathrm{ft}$ (Chapter 3), which is 15.7\% thicker than Huffstutter Field at 216 ft. A closer examination of the LKC thickness is shown using example wells selected from each field (Figure 4-19). While the LKC section is thicker at Sleepy Hollow, it shows thicker mudstone units than Huffstutter. Moreover, Huffstutter appears to be more dominated by carbonates, which might suggest better storage opportunities.

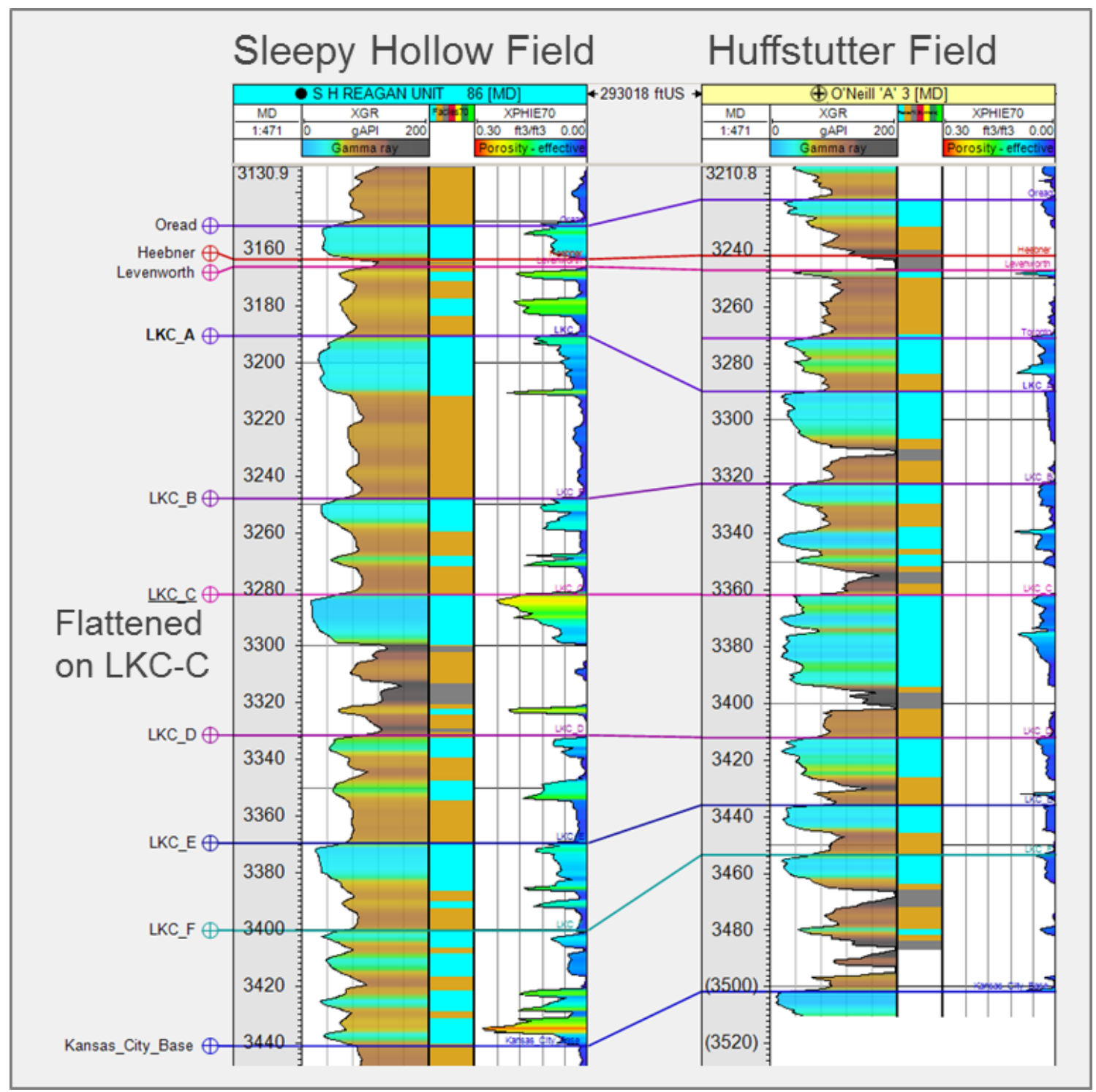

Figure 4-19. Example well correlation between Sleepy Hollow Field and Huffstutter Field. Well section is flattened on the LKC-C. Left track: gamma ray. Central track: discrete GR facies log (0: Carbonatedominant, 1: mudrock-dominant, 2: shale-dominant). Right track: effective porosity log. 
Based on the SEMs, a volumetric comparison, by facies, for these two fields are shown in Figures 4-20 and 4-21. Sleepy Hollow Field is dominated by mudrock at $50.3 \%$ by volume. Huffstutter is dominated by carbonate rock at $58.9 \%(55.4 \%+3.5 \%)$ (Figure $4-21)$.

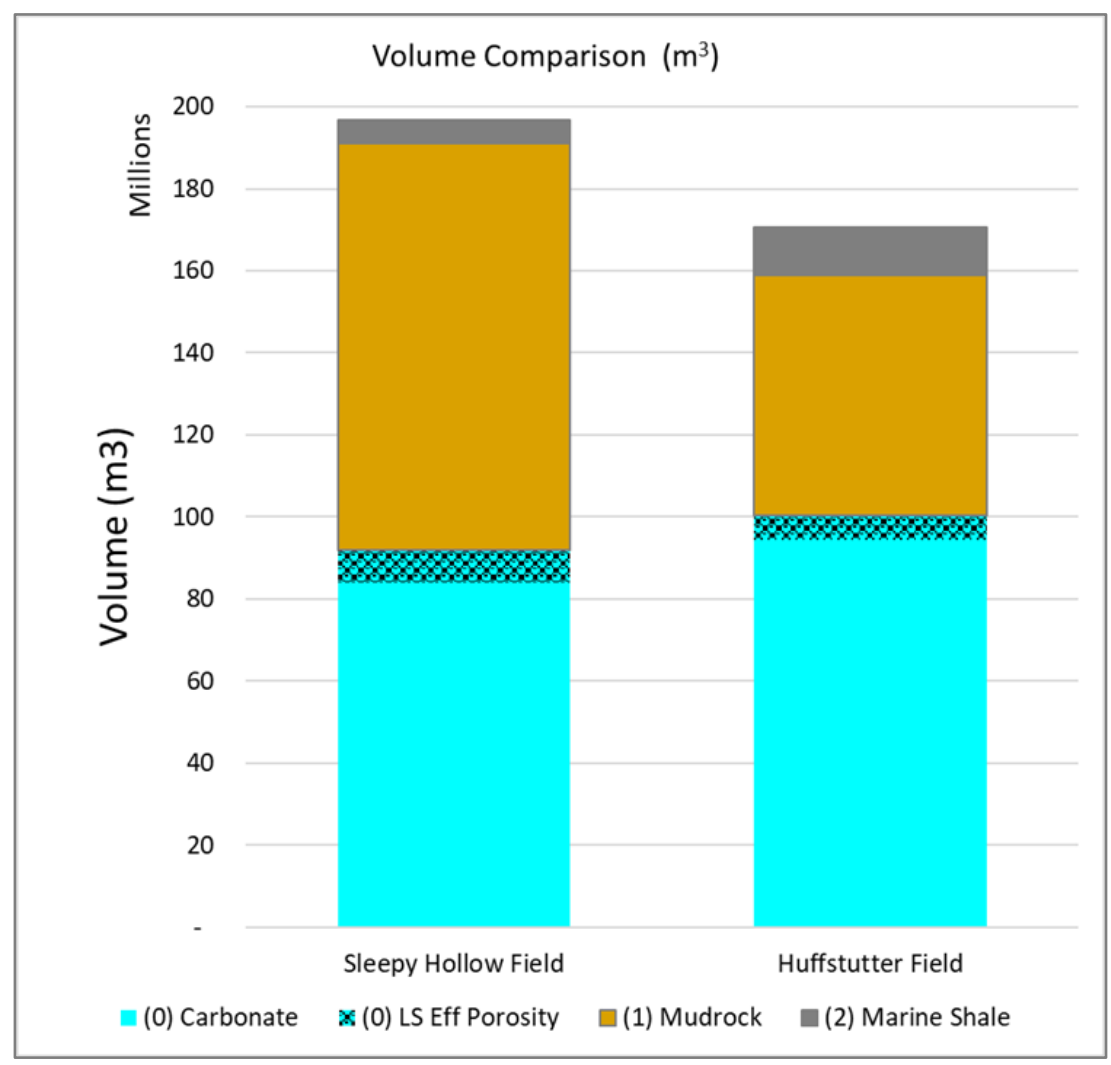

Figure 4-20. Comparison of LKC volume by GR facies based on SEMs from Sleepy Hollow and Huffstutter Fields. The LS Eff represents the actual effective porosity volume among the carbonate-dominant intervals. 


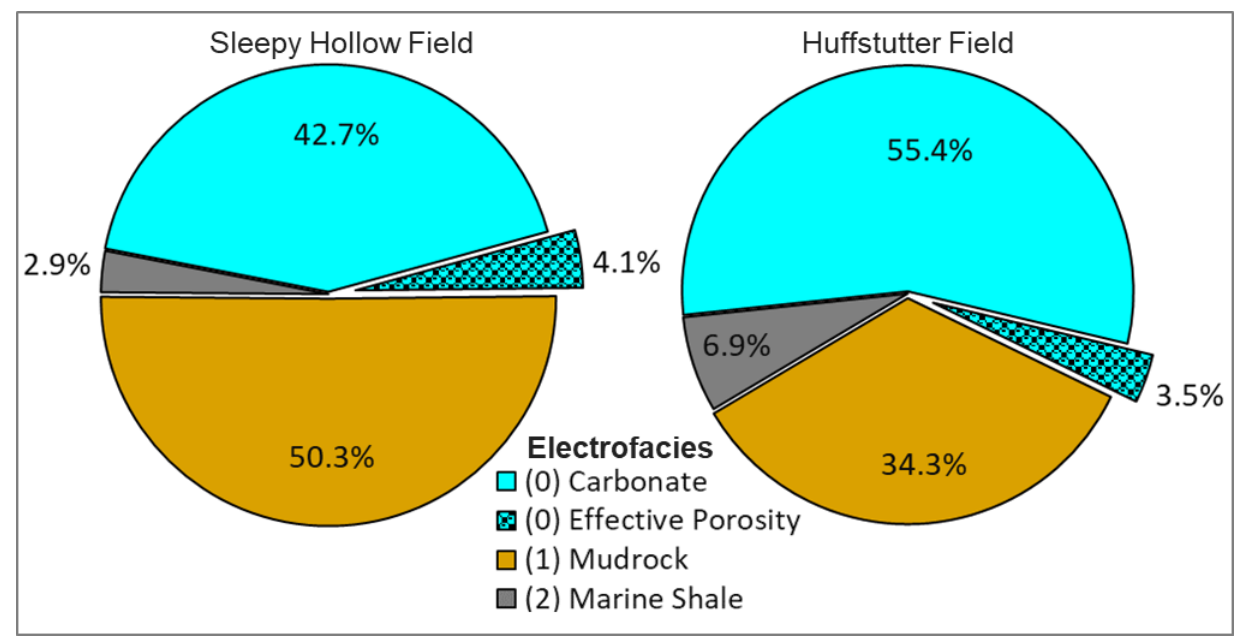

Figure 4-21. A percentage-wise comparison of LKC volume by facies based on SEMs from Sleepy Hollow and Huffstutter Fields. The carbonate effective porosity volume is rendered as a separate slice.

Huffstutter has more carbonate rock both volumetrically and percentage-wise when compared to Sleepy Hollow and would appear to have a $\mathrm{CO}_{2}$ storage advantage, (Figures 4-20 and 4-21). However, Sleepy Hollow has higher porosities. Figure 4-22 shows a histogram of LKC effective porosities for carbonate units (GR facies code 0) for these two fields. At Sleepy Hollow, we see thicker mudstones during regression, and this relates to a more landward position, which may have provided limestone units better opportunity for porosity development during periods of subaerial exposure.

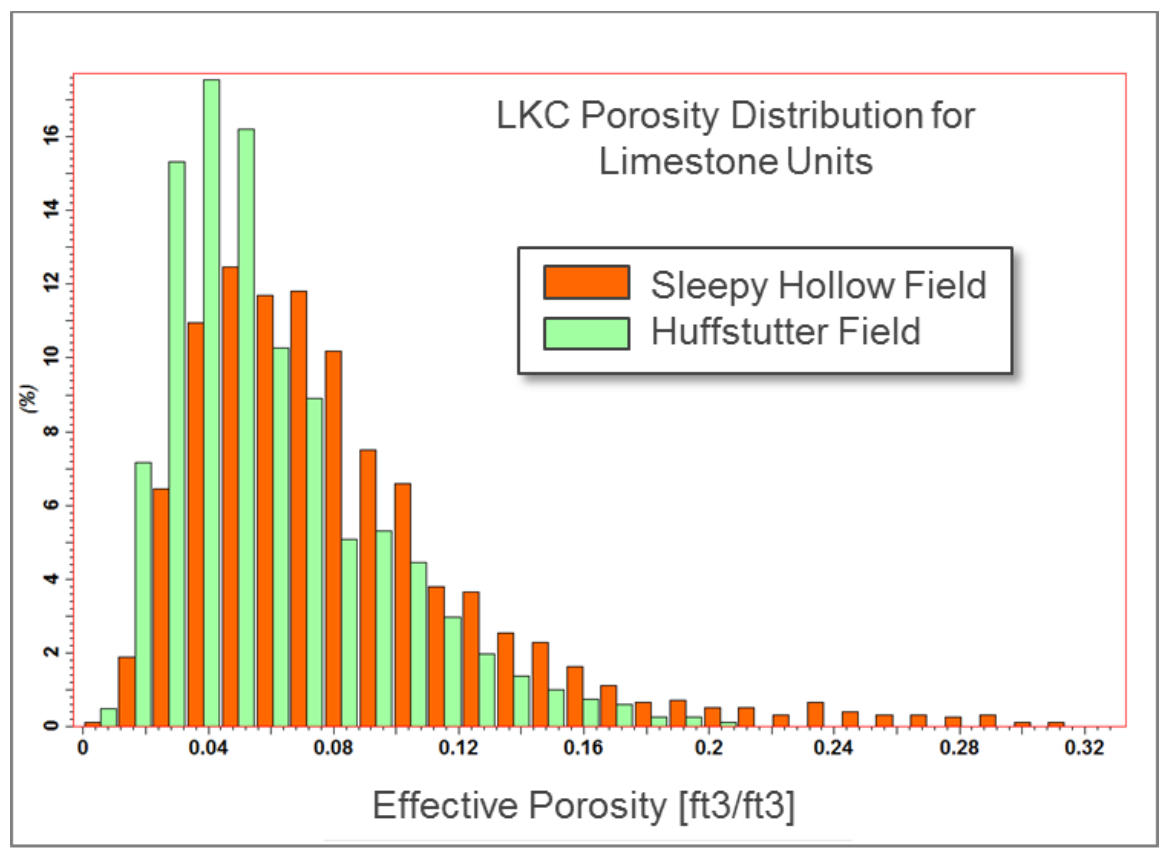

Figure 4-22. Comparison of SEM effective porosity for LKC limestone units of Sleepy Hollow and Huffstutter Fields (filtered on GR facies code 0 ). 
Naturally, $\mathrm{CO}_{2}$ density also plays a role in computing the storage for the LKC. With the top of the LKC at Huffstutter being 140 feet (43 m) deeper than at Sleepy Hollow, we expect to see higher pressure and higher temperature. Interestingly, the higher temperature at Huffstutter has the effect of decreasing the $\mathrm{CO}_{2}$ density at reservoir conditions. The mean $\mathrm{CO}_{2}$ density for the two fields is approximately $746 \mathrm{Kg} / \mathrm{m}^{3}$, with less than $0.1 \%$ difference (Figure $4-23 a$ ). The minimum, maximum, and mean effective porosity for each field (Figure 4-23b) indicates that the effective porosity is the key driving difference between the two fields (Figure 4-23c). Sleepy Hollow's LKC carbonates have a mean effective porosity of 0.086, whereas Huffstutter's mean is 0.058 . The computed $\mathrm{CO}_{2}$ mass per cell reflects the range of values based on the SEM, equation 4-6, and filtering on GR facies code 0 (carbonate rock), (Figure 4-23c).

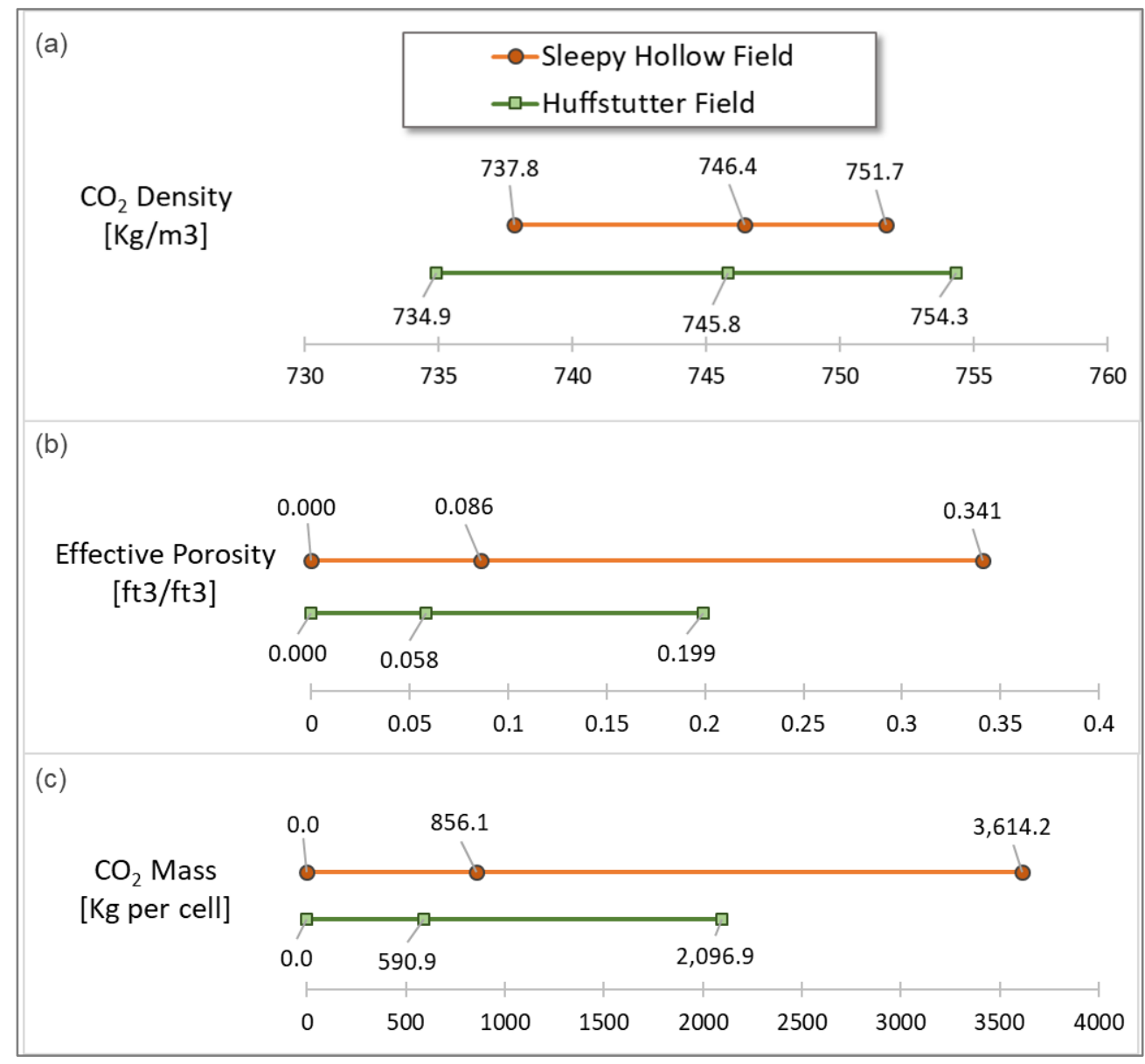

Figure 4-23. Comparison of SEM properties filtered on carbonate rock, GR facies code 0 . From left to right, lines show minimum, mean, and maximum values. (a) $\mathrm{CO}_{2}$ density at reservoir conditions. (b) Effective porosity for carbonate rocks. (c) Range of computed $\mathrm{CO}_{2}$ mass per cell. Model cell size is $50 \times 50 \times 2$ feet for both SEMs. 
Lastly, porosity-foot net maps were prepared for both the LKC at Sleepy Hollow and Huffstutter SEMs using equation 4-7. This calculation was filtered on carbonate rock where GR faces code $=0$. The net maps show that the LKC in the Sleepy Hollow area has better reservoir quality than Huffstutter Field (Figure 4-24), and this is consistent with the results presented above.

$\mathrm{Z}=\operatorname{Sum}[\mathrm{P}(\mathrm{i}) * \operatorname{Height}(\mathrm{i})]$

where

[Eq. 4-7]

$\mathrm{P}(\mathrm{i})=$ effective porosity at each $(\mathrm{x}, \mathrm{y})$ position

Height $(\mathrm{i})=$ cell height at each $(\mathrm{x}, \mathrm{y})$ position

$\mathrm{Z}$ is the total porosity-footage at each $(\mathrm{x}, \mathrm{y})$ position.

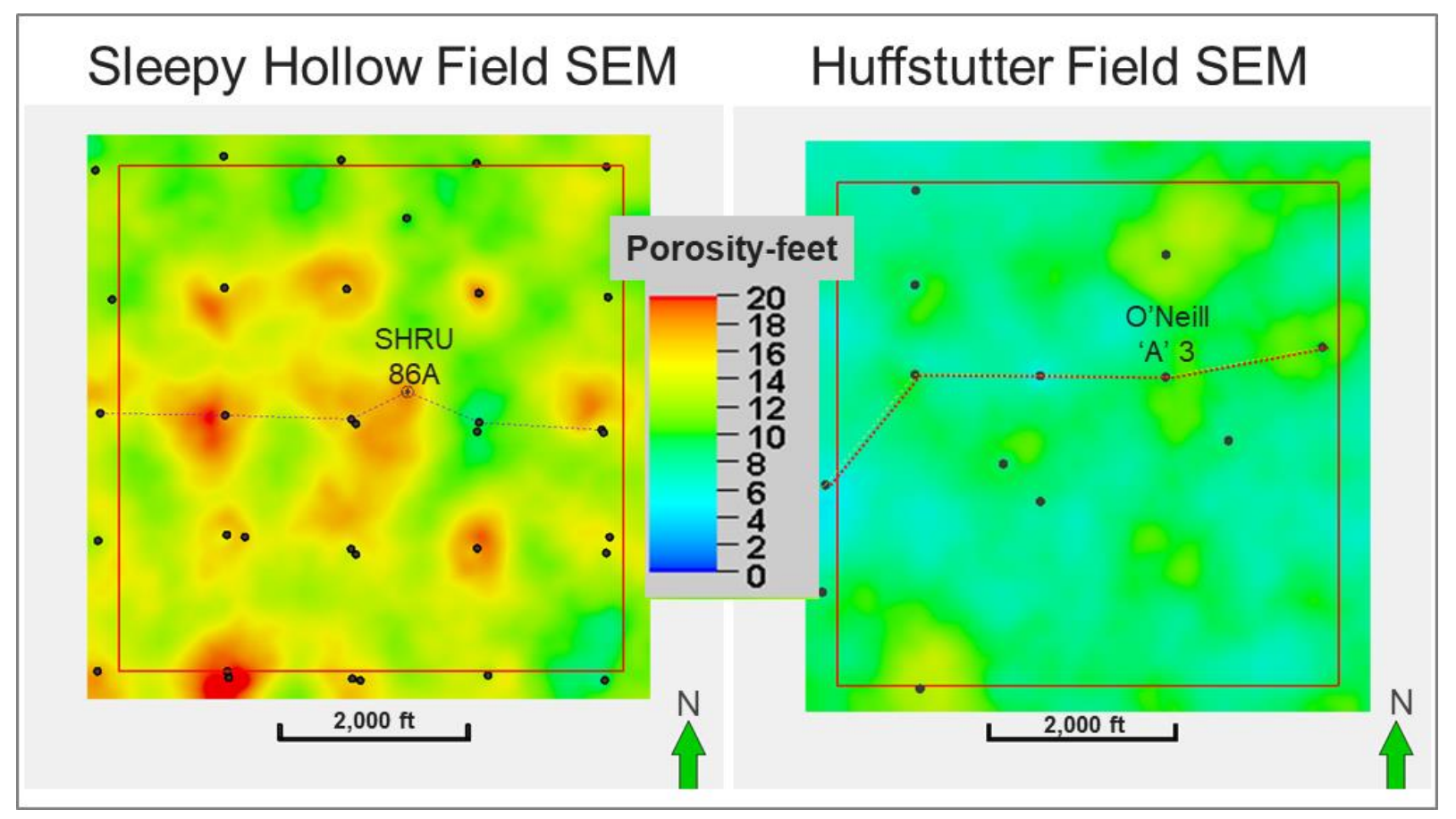

Figure 4-24. Porosity-foot net maps for the LKC section for Sleepy Hollow and Huffstutter SEMs. Net maps computed for carbonate rock intervals; GR facies code 0 . SEMs are 6,000ft ${ }^{2}$. Red boxes represent 1 square mile regions used for computing $\mathrm{CO}_{2}$ storage estimates. Dashed red lines are cross-sections presented earlier. 


\section{Summary and Conclusions}

The Huffstutter Field LKC Groups serve as an excellent example of the Kansas-type cyclothems. The $\mathrm{CO}_{2}$ storage assessment completed in this study is based on a fine-scale 3D geocellular model and, in terms of resolution, facies modeling, and quantitative storage results, represents the most detailed model of its kind for midcontinent Pennsylvanian cyclothems. The storage capacity estimates made in this study are focused on regressive limestones that represent key $\mathrm{CO}_{2}$ storage intervals. The GR response of 70 gAPI or less was used to identify clean carbonate intervals. This criterion targets porous carbonate rock that is potentially accessible for $\mathrm{CO}_{2}$ storage. The analysis presented here shows $\mathrm{CO}_{2}$ storage potential in Pennsylvanian carbonates. Within these carbonate cycles, GR log values greater than 70 are generally blocky red mudstones, or mixed limestone having a significant clay component that would occlude pore space. GR values greater than 120 correlates with grey, dark, or black, transgressive marine shale. These GR thresholds form the basis of the GR facies model that depicts the succession on carbonate and mudrock units of the LKC. The static earth model can be used to determine the best location for potential injection wells.

Based on the SEM derived from Huffstutter well logs, the LKC here can potentially store 443,355 tonnes $\mathrm{CO}_{2} / \mathrm{mile}^{2}\left(171,180\right.$ tonnes $\left.\mathrm{CO}_{2} / \mathrm{km}^{2}\right)$ using a saline storage efficiency factor of 0.1 . The LKC section was thinner at Huffstutter Field than at Sleepy Hollow Field to the northwest but offered more gross footage of carbonate rock. However, Sleepy Hollow provided higher effective porosity, and the net result was that Sleepy Hollow's LKC section offered better storage at 602,157 tonnes/mile 232,494 tonnes $/ \mathrm{km}^{2}$ ). At Huffstutter, the thickness of the individual regressive carbonates, typically less than $18 \mathrm{ft}$ $(5.5 \mathrm{~m})$, is an important constraint for developing a full scale, 50 million tonne, $\mathrm{CO}_{2}$ storage site.

Preliminary modeling and flow simulation work have shown that 4 injection wells are required and that perforation into all favorable Pennsylvanian carbonates underlying and overlying the LKC is required to achieve 50 million tonnes of $\mathrm{CO}_{2}$ storage (Battelle, 2018). This $\mathrm{CO}_{2}$ injection strategy would require 
multiple perforations and multiple wells to limit well interference. Still, these Pennsylvanian carbonates, like those in the LKC, can be attractive for smaller-scale commercial projects.

The basal Arbuckle limestone may offer storage potential at Huffstutter but was not the focus of this paper. Ongoing work by the author includes storage assessments to the west and east of the Cambridge Arch and Central Kansas Uplift. The addition of the Arbuckle, the Meramec, Viola, and undifferentiated limestones of the Silurian and Devonian may provide significant storage opportunity to compliment the overlying Pennsylvanian cyclic carbonates.

This modeling approach can also be incorporated into the assessment of CO2-EOR activities in LKC oil-bearing intervals. It is believed that the Pennsylvanian LKC section will offer the best opportunity for this kind of operation in this region. Oil production at Huffstutter Field is from LKC zones "E" and "F." The specific productive zones can vary by field. In most cases, these are mature oilfields prime for CO2-EOR. The workflow developed here can be applied to other oilfields in the area and used for oil production and management of hydrocarbon resources or used as the framework for saline storage estimates and the evaluation of $\mathrm{CO}_{2}$ injection plans.

\section{Acknowledgments}

The research for the Integrated Mid-continent Stacked Carbon Storage Hub (IMSCS HUB) project is supported by the U.S. Department of Energy - National Energy Technology Laboratory Agreement No. DE-FOA-0031623 and No. DE-FE0029264. The data supplied in this study were acquired in collaboration with the Conservation and Survey Division, School of Natural Resources, University of Nebraska-Lincoln, and through Great Plains Energy, Inc., Lincoln, NE. Existing oilfield data was acquired through the Nebraska Oil and Gas Commission and the Kansas Geological Survey Oil and Gas database. 


\section{References}

Appel, M., 2004, Nuclear Magnetic Resonate and Formation Porosity, Petrophysics, vol., 45, no. 3, p. 296-307.

Asquith, G. and Krygowski, D., 2006, Basic Well Log Analysis, Second Edition, AAPG, ISBN:9780891816676, $244 \mathrm{p}$.

Battelle Memorial Institute, 2018, Integrated Mid-Continent Stacked Carbon Storage Hub, Task 3 SubBasinal Geologic Assessment Topical Report, DOE Agreement/Project \# DE-FE0029264

[ https://www.osti.gov/biblio/1478726-integrated-mid-continent-stacked-carbon-storage-hub-phase-finalreport ]

Battelle Memorial Institute, 2019 (in review), Integrated Mid-Continent Stacked Carbon Storage Hub Project Phase II, Storage Complex Data Collection Plan, Task 3 Feasibility Data Collection Planning, DOE Agreement/Project \# DE-FE0031623

Dubois, M.K., 1985, Application of cores in development of an exploration strategy for the LansingKansas City "E” zone, Hitchcock County, Nebraska: Kansas Geological Survey, Subsurface Geology Series 6, p. 120-132.

Evans, D.G, and Steeples, D.W., 1987, Microearthquakes Near the Sleepy Hollow Oil Field, Southwestern Nebraska, Bulletin of the Seismological Society of America, Vol 77, No. 1, p. 132-140

Fouda, M.A.G., 2016, Relative Permeability Upscaling for Heterogeneous Reservoir Models, Dissertation, Heriot-Watt University, Edinburgh, Scotland, 160 p.

Goodman, A.; Hakala, A.; Bromhal, G.; Deel, D.; Rodosta, T.; Frailey, S.; Small, M.; Allen, D.; Romanov, V.; Fazio, J.; Huerta, N.; McIntyre, D.; Kutchko, B.; Guthrie, G., 2011, U.S. DOE methodology for the development of geologic storage potential for carbon dioxide at the national and regional scale. International Journal of Greenhouse Gas Control, v. 5, p. 242-249.

Goodman, A., Sanguinito, S., Levine, J., 2016. Prospective $\mathrm{CO}_{2}$ resource estimation methodology: Refinement of existing US-DOE-NETL methods based on data availability, International Journal of Greenhouse Gas Control, v. 54, p. 952-965.

Larson, W.G., 1962, Ackman Field and Environments, Southwestern Nebraska: AAPG Bulletin V26., No. 11, pp. 2079-2089

Peck, W.D., Glazewski, K.A., Klenner, R.C.L., Gorecki, C.D., Steadman, E.N., and Harju, J.A., 2014, A workflow to determine $\mathrm{CO} 2$ storage potential in deep saline formations: Energy Procedia, v. 63, p. 52315238.

Rogers, J.P., 1977, Genesis and Distribution of Desmoinesian (Pennsylvanian) Sandstone Reservoir, Sleepy Hollow Field, Red Willow County, Nebraska, The American Association of Petroleum Geologists Bulletin, V. 61, No. 7, p. 1029-1044 
Steeples, D.W., 1982, Structure of the Salina-Forest City interbasin boundary from seismic studies. Kansas Geological Survey Bulletin 226, Geophysics in Kansas, p. 31-52.

http://www.kgs.ku.edu/Publications/Bulletins/226/Steeples/

Watney, W.L, 1980, Cyclic sedimentation of the Lansing-Kansas City Groups in northwestern Kansas and southwestern Nebraska: Kansas Geological Survey, Bulletin 220

Young, A.L., 2011, Lithostratigraphy and Diagenesis of the Upper Pennsylvanian (Missourian) LansingKansas City Groups in Rooks County, Kansas, M.S. Thesis, Wichita State University 


\section{Chapter 5: Highlights and Future Work}

\section{Highlights}

This dissertation presents the development of two static earth models representing Upper Pennsylvanian cyclothems of midcontinent, USA. The purpose of these models is to establish the petrophysical framework necessary for estimating $\mathrm{CO}_{2}$ storage capacity on the Cambridge Arch of southwestern Nebraska and the Central Kansas Uplift in Kansas. The interpretations and workflows were developed to serve the Integrated Midcontinent Stacked Carbon Storage (IMSCS) Hub Project as part of DOE-NETL's Carbon Storage Assurance Facility Enterprise (CarbonSAFE) initiative. One objective of the CarbonSAFE project is to develop a regional carbon storage hub where captured carbon will be piped from $\mathrm{CO}_{2}$ sources (commonly corn ethanol plants) to existing oilfields for carbon storage and potentially enhanced oil recovery (EOR). Scope of work and funding for the CarbonSAFE projects specify the evaluation of saline formations for $\mathrm{CO}_{2}$ storage.

This research details my subsurface interpretations in the area of Sleepy Hollow Field in Nebraska and Huffstutter Field in Kansas. In both areas, there is a fundamental, limited $\mathrm{CO}_{2}$ storage window between 2,600 ft (792m) measured depth and Precambrian basement rock at $\sim 3,500 \mathrm{ft}+/-300 \mathrm{ft}(1067 \mathrm{~m}+/-91.4 \mathrm{~m})$. This window is comprised of Pennsylvanian cyclothems consisting of alternating beds of carbonate rock, mudstones, and shale. The Lansing and Kansas City Groups (LKC) represent a portion of this section and contains both saline and oil-bearing intervals in Nebraska and Kansas. Due to oil production, many well logs are available for these sections.

Although there a number of papers discussing the LKC (Burchett, 1983; Dubois, 1985; Heckel, 1986; Watney, 1980), this is the first time the LKC has received highly detailed 3D, geocellular, petrophysical modeling. The LKC was selected because it represents some of the better developed and preserved features of a "Kansas-type" cyclothem model (Figure 2-2). Gamma ray logs correlate with the Kansas-type cyclothem model, which I've validated and substantiated with core samples, thin sections, and 
core data (Figure 3-6). This model can be used to facilitate interpretation of the Upper Pennsylvanian section in this area. However, the use of this cyclothem model becomes less intuitive in the overlying Wabaunsee and Shawnee Groups and the underlying Pleasanton and Marmaton Groups (Figure 1-3). Presumably, the periodicity and amplitude of eustatic conditions in this area were less favorable for producing the cycles we see in the LKC Groups. Still, gamma ray logs for these intervals are good indicators for discriminating limestone rock from mudstones.

My initial correlation of stratigraphic units between Sleepy Hollow Field and Huffstutter Field presented a number of challenges; the most obvious issue was stratigraphic nomenclature. While field-scale and even county scale correlation of LKC units were possible, expanding the correlation into adjacent counties and across the Nebraska and Kansas state border became complicated. In Chapter 2, I set out to resolve these differences, and I recognized that a better understanding of the "Kansas-type" cyclothem model (Heckel, 1986) would be a valuable key. I used this model in a regional well correlation traced to LKC outcrops in eastern Kansas. I learned that this model is a great starting point for subsurface interpretation, but that various members of LKC can frequently be absent or conspicuously thick depending on location in the shallow epicontinental sea. An outgrowth of this research describes and illustrates how the gamma ray expression for these cyclic units change in the uplifted areas of the Cambridge Arch and the Central Kansas Uplift. Most notably, deeper, transgressive marine shales occur with less frequency, and that there is thicker development of regressive, siliciclastic mudstones.

Gamma ray logs were very common and served as the basis for developing a gamma ray facies model that broadly highlights three lithologies. Through validation with core samples (Figure 3-6) and advanced logging (Figure 3-7) at Sleepy Hollow Field (June 2019, SHRU 86A well), I base my facies model on GR log thresholds as summarized below. 
GR < 70 gAPI: Carbonate-dominated, oolitic, peloidal, and skeletal grainstones are of special interest as reservoir rocks. It also includes other carbonate rock types, including tighter lime-mudstones and wackestones.

70 gAPI <GR < 120 gAPI: Mudstone-dominated, includes reddish siliciclastic mudstones, with pedogenetic features.

GR > 120 gAPI Black or dark gray shale. At SHF, usually absent.

The GR facies model was used for SEMs in both fields and represented the fundamental framework for controlling how porosity and permeability are distributed. Because the LKC formed on a very broad and relatively flat area of the midcontinent, the distribution of the three facies described above has a layercake, aggradation appearance on a field-scale and county scale. Based on well logs, evidence for progradation or retrogradation is not obvious and would require a broader investigation elsewhere on the platform where these effects may be apparent. Moreover, for SEM development, the GR facies model enabled refinement in the preparation of effective porosity logs for the Pennsylvanian section. For example, neutron porosity logs were very sensitive to clay-bound water porosity within the regressive mudstone units and placed mudstone porosity greater than limestone reservoir porosity. For SEM purposes, it was sensible to produce an effective porosity model where the effective porosity of carbonate reservoir rock is greater than that of the siliciclastic regressive mudstones, i.e., seals. The rationale for this came from permeability measurements on regressive mudstone core samples that produced values on the order of 0.001 millidarcies and porosity around $15 \%$. Clearly, these are tight rocks and should be modeled as such. Thus, the GR facies model was used to select the tight, siliciclastic, regressive mudstones intervals (and the transgressive marine shales) and apply attenuation to the neutron porosity log for more realistic effective porosity log over mudrock intervals. Neutron porosity log values for clean carbonate intervals were unmodified and considered a reliable measure of effective porosity.

The SEMs in this dissertation are a little over 1-mile square and are representative of LKC carbonate cyclicity found in their respective field areas, Sleepy Hollow Field and Huffstutter Field. While I've developed full, field-scale SEMs for both of these study areas (Battelle, 2018 and 2019), the research 
presented here provided an opportunity for a focused analysis of the cyclothems, refinement of the SEM workflow, and a chance to compare stratigraphic and storage differences between the two sites. Furthermore, the area of the 1-mile square is representative of many smaller oilfields, and in general, is a good basis for estimating saline storage in the vicinity of corn ethanol $\mathrm{CO}_{2}$ point sources in the absence of LKC oilfields.

In comparing $\mathrm{CO}_{2}$ storage differences, I've determined that Sleepy Hollow Field has less carbonate rock by volume but has better porosity development than found at the Huffstutter Field site. The net effect is that the conditions for $\mathrm{CO}_{2}$ storage in the LKC at Sleepy Hollow Field are more favorable than at Huffstutter Field.

The application of the $\mathrm{CO}_{2}$ mass equation (Eq. 5-1) directly in Petrel has been one of the outgrowths of my research and required preparing pressure and temperature models for the estimation of $\mathrm{CO}_{2}$ density as a function of depth (Figure 3-17 and 4-16). These models are based on measurements derived from Drill Stem Testing at Sleepy Hollow Field. While the production of effective porosity maps commonly falls to geologists, and the pressure and temperature models fall to reservoir engineers, the work presented here has bridged that gap towards the estimation of potential $\mathrm{CO}_{2}$ storage mass at reservoir conditions through the mass equation below. Equation 5-1 was applied on a geocellular level, that is, cell-by-cell within the 3D geocellular, petrophysical model.

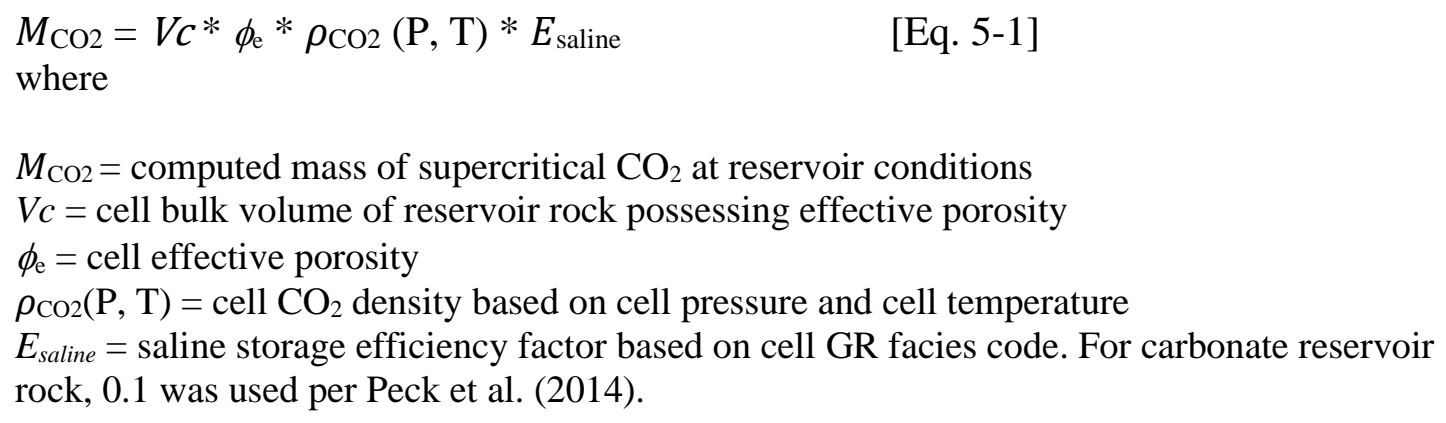

$\mathrm{CO}_{2}$ mass equations, like the one above, are commonly used by regional carbon storage partnerships. Generally, there are significant uncertainties around net storage thickness, storage area, and effective porosity. As applied in my LKC research (Chapters 3 and 4), area, depth, volume, effective 
porosity, pressure, temperature, and estimated $\mathrm{CO}_{2}$ density are accurately constrained. $E_{\text {saline }}$ is the saline storage efficiency factor and reflects limitations to the accessibility of pore space. Pore space accessibility varies by rock type, pore throat, and diagenesis of the rock. A storage efficiency factor of 0.1 was selected here as it represents the $\mathrm{p} 10$ level, a conservative estimate, for limestone rock. A conservative estimate was appropriate because permeability for the carbonate rocks was commonly less than $100 \mathrm{mD}$ and frequently less than $10 \mathrm{mD}$. Based on the SEMs in Chapters 3 and 4, results show that for Sleepy Hollow's LKC, storage is estimated at 602,157 tonnes $\mathrm{CO}_{2} /$ mile $^{2}\left(232,494\right.$ tonnes $\left.\mathrm{CO}_{2} / \mathrm{km}^{2}\right)$, and Huffstutter is 443,355 tonnes $\mathrm{CO}_{2} /$ mile $^{2}\left(171,180\right.$ tonnes $\left.\mathrm{CO}_{2} / \mathrm{km}^{2}\right)$ when using a storage efficiency factor of 0.1 .

My subsurface interpretations of the LKC coupled with the development of 3D facies and petrophysical models, embody the most comprehensive representation of Pennsylvanian cyclothems ever prepared for sites in Nebraska and Kansas. The workflows developed in this research lay the foundation for LKC modeling in this region and can be applied to the evaluation of $\mathrm{CO}_{2}$ storage opportunities, as well as for the development of mature LKC plays.

\section{Future Work}

Geologic storage resources are commonly evaluated by applying NETLCO2-SCREEN (Goodman et al., 2016), a software that provides an EXCEL-based data input interface and a stochastic treatment to yield p10, p50, and p90 estimates for $\mathrm{CO}_{2}$ storage. This application requires the distillation of an SEM, regardless of size, down to a maximum of 300 cells (values) describing reservoir depth, thickness, and porosity. This exercise is further complicated when dealing with stacked-storage injection strategies. It is unclear how the upscaling to 300-cells affects the final storage estimates. My ongoing research seeks a more robust solution that aims to employ the methods described by Goodman et al. (2016) and directly apply them within the Petrel modeling environment. This would take advantage of exiting Petrel software tools to form a fully integrated, self-contained workflow for estimating a $\mathrm{CO}_{2}$ storage resource without having to export elements of an SEM that have been subjected to significant averaging. Furthermore, 
storage efficiency factors that pertain to oil-bearing units could also be integrated as part of a full solution for a stacked-storage strategy that includes both saline and hydrocarbon units.

Another ongoing aspect of my research in 2020 is the evaluation of $\mathrm{CO}_{2}$ storage sites both on and off the Cambridge Arch. Of particular interest is the correlation of LKC units east and west of the Arch and the Central Kansas Uplift. Currently underway are $\mathrm{CO}_{2}$ storage assessments eastward into Harlan, Kearney, and Buffalo Counties of Nebraska. There is less oilfield development in this area, but the LKC is present here and is of sufficient depth for $\mathrm{CO}_{2}$ storage. Eastward of the Cambridge Arch, we have a deepening of the sedimentary section in the Central Nebraska Basin (northern portion of the Salina Basin). Of increasing interest in this area is the presence of deeper, thicker carbonate units of Mississippian and Ordovician age. Because of their thickness, these deeper units may afford better storage opportunity than that seen in the $\mathrm{LKC}$, or together, may provide better storage capacity for $\mathrm{CO}_{2}$ point-source sites in the area. 


\section{References}

Battelle Memorial Institute, 2018, Integrated Mid-Continent Stacked Carbon Storage Hub, Task 3 SubBasinal Geologic Assessment Topical Report, DOE Agreement/Project \# DE-FE0029264

[ https://www.osti.gov/biblio/1478726-integrated-mid-continent-stacked-carbon-storage-hub-phase-finalreport ]

Battelle Memorial Institute, 2019 (in review), Integrated Mid-Continent Stacked Carbon Storage Hub Project Phase II, Storage Complex Data Collection Plan, Task 3 Feasibility Data Collection Planning, DOE Agreement/Project \# DE-FE0031623

Burchett, R.R., 1983, Surface to Subsurface Correlation of Pennsylvanian and Lower Permian Rocks Across Southern Nebraska, Nebraska Geology Survey, Report of Investigation \#8.

Dubois, M.K., 1985, Application of cores in development of an exploration strategy for the LansingKansas City "E" zone, Hitchcock County, Nebraska: Kansas Geological Survey, Subsurface Geology Series 6, p. 120-132.

Goodman, A., Sanguinito, S., Levine, J., 2016. Prospective CO2 resource estimation methodology: Refinement of existing US-DOE-NETL methods based on data availability, International Journal of Greenhouse Gas Control, v. 54, p. 952-965.

Heckel, P. H., 1986, Sea-level curve for Pennsylvania eustatic marine transgressive-regressive depositional cycles along midcontinent outcrop belt, North America: Geology, v. 14, p. 330-334.

Peck, W.D., Glazewski, K.A., Klenner, R.C.L., Gorecki, C.D., Steadman, E.N., and Harju, J.A., 2014, A workflow to determine $\mathrm{CO} 2$ storage potential in deep saline formations: Energy Procedia, v. 63, p. 52315238 .

Watney, W.L, 1980, Cyclic sedimentation of the Lansing-Kansas City Groups in northwestern Kansas and southwestern Nebraska: Kansas Geological Survey, Bulletin 220 